\begin{tabular}{|l|l|}
\hline $\begin{array}{l}\text { 2. To: (Receiving Organization) } \\
\text { Distribution }\end{array}$ & $\begin{array}{l}\text { 3. from: (originating Orgarization) } \\
\text { Data Assessment and } \\
\text { Interpretation }\end{array}$ \\
\hline $\begin{array}{l}\text { 5. Proj./Prog./Dept./Div.: } \\
\text { Tank 241-U-110/Waste } \\
\text { Management/DAI/TWRS } \\
\text { Technica } 7 \text { Basis }\end{array}$ & $\begin{array}{l}\text { 6. cog. Engr.: } \\
\text { Todd M. Brown }\end{array}$ \\
\hline $\begin{array}{l}\text { 8. originator Remarks: } \\
\text { This document is being released into the supporting document } \\
\text { system for retrievability purposes. }\end{array}$
\end{tabular}

11. Receiver Remarks:

For release.
4. Related EDT

$N / A$

7. Purchase Order No.: N/A

9. Equip./Component No.: N/A

10. System/Bldg./Facility: 241-U-110

12. Major Assm. Dwg. No.: $N / A$

13. Permit/Permit Application No.: $N / A$

14. Required Response Date: $05 / 23 / 96$

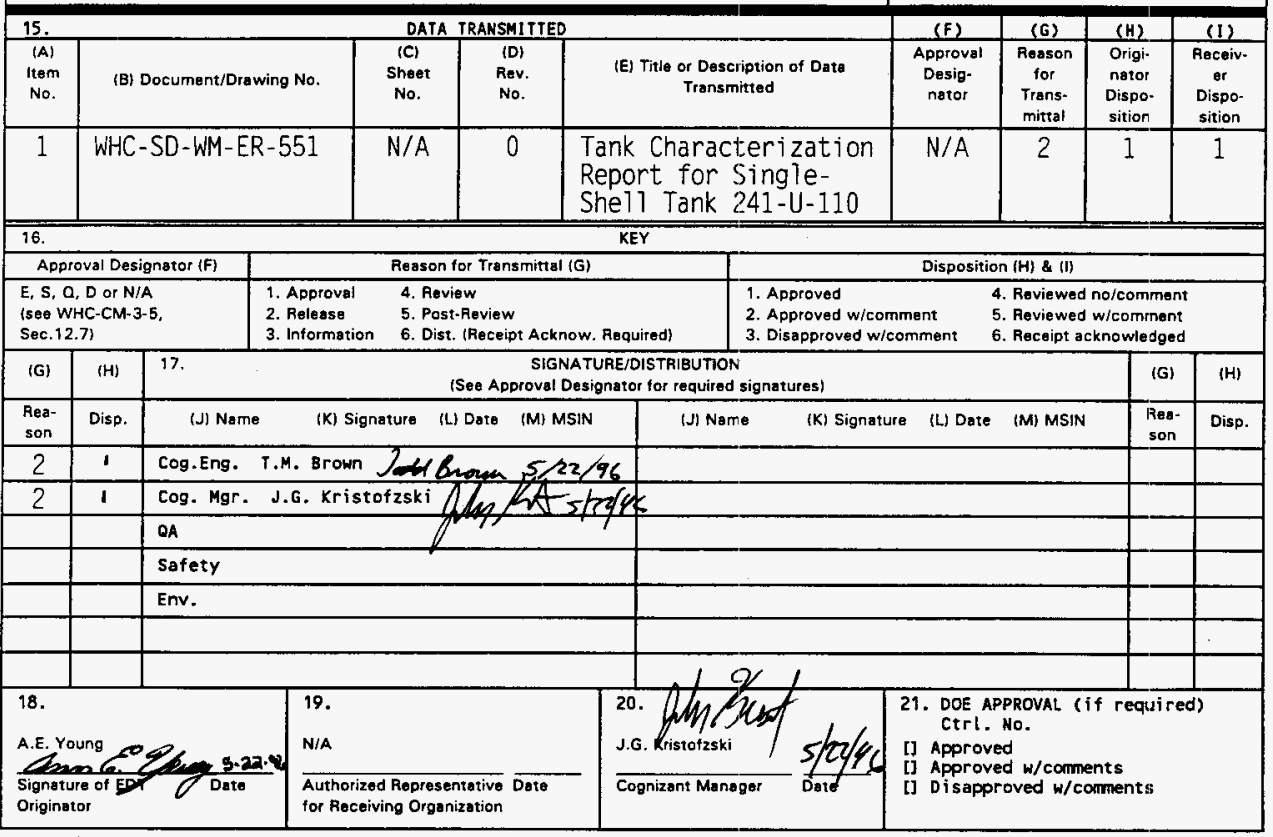




\section{Tank Characterization Report for Single-Shell Tank 241-U-110}

\section{Todd M. Brown}

Westinghouse Hanford Company, Richland, WA 99352

U.S. Department of Energy Contract DE-AC06-87RL10930

$\begin{array}{lll}\text { EDT/ECN: } & \text { EDT-615395 } & \text { UC: } 2070 \\ \text { Org Code: } & 79400 & \text { Charge Code: } \\ \text { B\&R Code: } & \text { EW } 3120074 & \text { Total Pages: } 1 / 6\end{array}$

Key Words: Tank 241-U-110. Tank U-110, IJ-110, U Farm. Tank Characterization Report. TCR, Single-Shell

Abstract: This tank characterization report for Tank 241-U-110 was initially released as WHC-EP-0643. This document is now being released as WHC-SD-WM-ER-551 in order to accommodate internet publishing. TRADEMARK DISCLAIMER. Reference herein to any specific comercial product, process, or service by
trade name, trademark, manufacturer, or otherwise, does not necessarily constitute or imply its
endorsement, recommendation, or favoring by the United States Government or any agency thereof or $i$ ts contractors or subcontractors.

Printed in the United States of America. To obtain copies of this document, contact: WHC/BCS Document Control Services, P.O. Box 1970, Mailstop H6-08, Richland WA 99352, Phone (509) 372-2420; Fax (509) 376-4989.
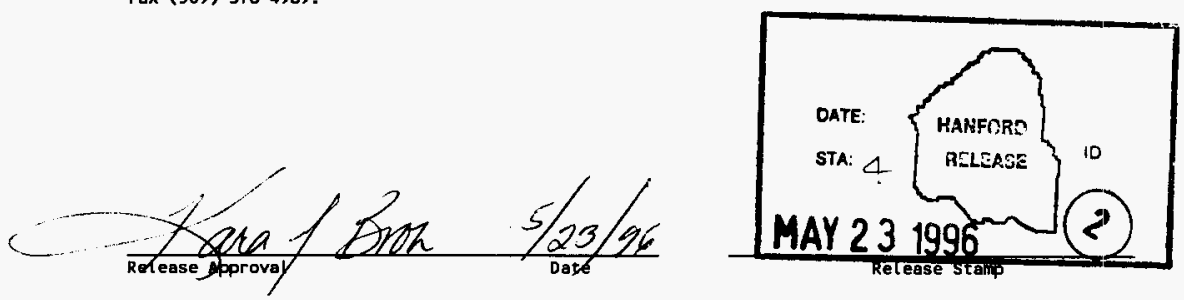

\section{Approved for Public Release}




\title{
Tank Characterization Report for Single-Shell Tank 241-U-110
}

\author{
T. M. Brown \\ L. Jensen
}

Date Published

May 1996

Prepared for the U.S. Department of Energy

Assistant Secretary for Environmental Management

\section{(2)




\section{EXECUTIVE SUMMARY}

Tank $241-\mathrm{U}-110$ (U-110) is a Hanford Site waste tank that was most recently sampled in November and December 1989. Analysis of the samples obtained from tank U-110 was conducted to support the characterization of the contents of this tank and to support Hanford Federal Facility Agreement and Consent Order milestone M-10-00 (Ecology et al. 1992). Because of incomplete recovery of the waste during sampling, there may be bias in the results of this characterization report.

The waste in tank U-110 is a heterogeneous mixture of water, metal hydroxides and oxides, and inert salts. The top 10 to $38 \mathrm{~cm}$ of the waste consists of a layer of hard, white material. This white material consists primarily of aluminum hydroxide $\left(\mathrm{Al}(\mathrm{OH})_{3}\right)$ and contains very little water (approximately 5 percent). The next $96 \mathrm{~cm}$ consists of a layer of softer brown sludge. This sludge is more moist than the top layer, with a water content of approximately 40 to 45 percent. The major cations in this sludge are aluminum and sodium. The aluminum is primarily in an insoluble form, likely aluminum oxide or aluminum hydroxide in the form of boehmite (AlOOH). The sodium generally occurs in a soluble form and is likely ionically bonded to the anions in the form of sodium salts. The major anions that are believed to be bonded with sodium are nitrate, nitrite, and fluoride. The bottom $48 \mathrm{~cm}$ of the tank consists of a layer of sludge that is chemically similar to the middle sludge layer of the tank. The primary difference between the bottom and middle sludge layer is that the bottom layer is very grainy in appearance and consistency and also has high proportions of bismuth and phosphate in addition to the analytes cornmon to the middle sludge layer. 
Both the bismuth and phosphate are in insoluble forms and are primarily found in the bottom of the tank, most likely in the form of bismuth phosphate. A summary diagram of these layers as they sit in the tank is given in Figure ES-1. A summary of the major analytes found in the tank is given Table ES-1, as well as a summary of important radionuclides.

The major analytes are shown as an average weight percent. The radionuclides are presented as an upper 95 percent confidence interval to present a conservative or "worst-case" estimate.

Figure ES-1. Summary of Layers in Tank U-110.

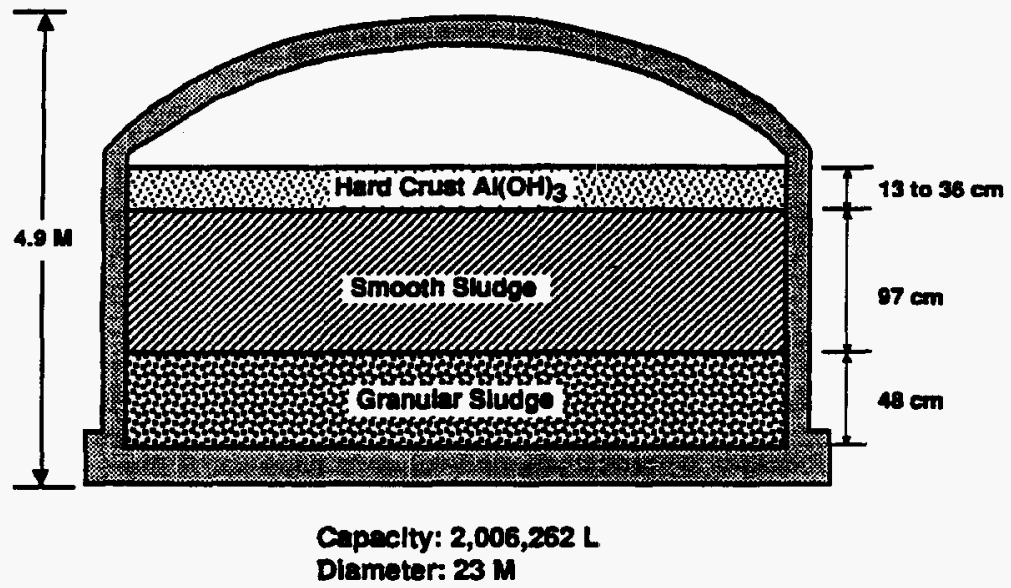

29304081.1 
Table ES-1. Major Analyte Inventory For U-110

\begin{tabular}{|c|c|c|}
\hline Analyte & \multicolumn{2}{|c|}{ Weight \% (wet values) } \\
\hline Water & \multicolumn{2}{|c|}{40.0} \\
\hline Al & \multicolumn{2}{|c|}{15.0} \\
\hline $\mathrm{Na}$ & \multicolumn{2}{|c|}{11.1} \\
\hline $\mathrm{NO}_{3}$ & \multicolumn{2}{|c|}{4.5} \\
\hline $\mathrm{PO}_{4}$ & \multicolumn{2}{|c|}{3.2} \\
\hline $\mathrm{Si}$ & \multicolumn{2}{|c|}{2.2} \\
\hline $\mathrm{Bi}$ & \multicolumn{2}{|c|}{2.1} \\
\hline $\mathrm{Fe}$ & \multicolumn{2}{|c|}{1.2} \\
\hline $\mathrm{NO}_{2}$ & \multicolumn{2}{|c|}{0.9} \\
\hline F & \multicolumn{2}{|c|}{0.7} \\
\hline U & \multicolumn{2}{|c|}{0.5} \\
\hline \multicolumn{3}{|c|}{ Fission Product Inventory } \\
\hline Fission Product & $\begin{array}{l}\text { Bulk Inventory } \\
\text { (Ci) }\end{array}$ & $\begin{array}{l}\text { Heat Generation } \\
\text { (W) }\end{array}$ \\
\hline Cs-137 & 41,000 & 190 \\
\hline Sr-90 & 480,000 & 3,200 \\
\hline \multicolumn{3}{|c|}{ Plutonium/Americium Inventory } \\
\hline Analyte & $\begin{array}{l}\text { Bulk Inventory } \\
\text { (Ci) }\end{array}$ & $\begin{array}{c}\text { Bulk Inventory } \\
\text { (g) }\end{array}$ \\
\hline $\mathrm{Pu}-239 / 240$ & 320 & 5,200 \\
\hline Am-241 & 118 & 34 \\
\hline
\end{tabular}

Comparisons of the analyte inventories to the various established safety criteria show that tank U-110 is within the safety requirements for gas-generating, ferrocyanide, high-heat, organic, and criticality tanks. The criteria that define these safety issues are compared to the inventories from tank U-110 in Table ES-2. Again, in these instances, the upper 
WHC-SD-WM-ER-551 Rev. 0

95 percent confidence interval value for the inventories are presented to depict a conservative or worst-case example.

Table ES-2. Comparison of Tank U-110 Analyte Values to Safety Issue Criteria*

\begin{tabular}{|l|c|c|}
\hline \multicolumn{1}{|c|}{ Safety category } & Safety criteria & Value for tank U-110 \\
\hline Ferrocyanide & $\begin{array}{c}1,000 \text { gram mole } \\
\text { ferrocyanide }\end{array}$ & $\begin{array}{c}\text { No cyanide detected in the } \\
\text { tank }\end{array}$ \\
\hline High heat & $40,000 \mathrm{Btu} / \mathrm{hour}$ & $11,600 \mathrm{Btu} / \mathrm{hour}$ \\
\hline Organic & $\begin{array}{c}\text { 3 dry weight \% total organic } \\
\text { carbon }\end{array}$ & $0.27 \mathrm{dry}$ wt\% \\
\hline Plutonium & $\begin{array}{c}50 \mathrm{~kg} \text { - total inventory } \\
\text { plutonium }\end{array}$ & $5.2 \mathrm{~kg}$ \\
\hline
\end{tabular}

*(Lindsey 1986, RHO 1988, Boyles 1992, Reep 1992). 


\section{CONTENTS}

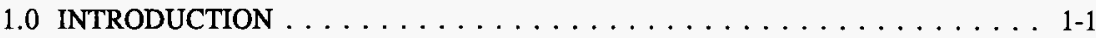

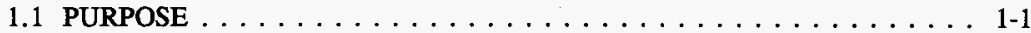

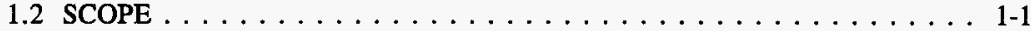

2.0 HISTORICAL INFORMATION AND EVALUATION $\ldots \ldots \ldots \ldots \ldots \ldots$ 2-1

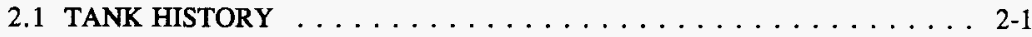

2.2 EXPECTED TANK CONTENTS ............... 2-6

2.3 HISTORICAL SAMPLING AND CHARACTERIZATION . . . . . . . 2-9

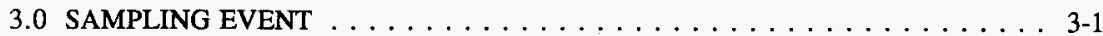

3.1 NUMBERING SYSTEM OF CORE SAMPLES $\ldots \ldots \ldots \ldots \ldots \ldots$. $\ldots \ldots$

3.2 DESCRIPTION OF SAMPLING EVENT $\ldots \ldots \ldots \ldots \ldots \ldots \ldots$ 3-2

3.3 RESULTS OF SAMPLING EVENT $\ldots \ldots \ldots \ldots \ldots \ldots \ldots \ldots . \ldots .3$

3.3.1 Segment Recoveries . . . . . . . . . . . . . . 3-3

3.3.2 Problems Encountered While Drilling . . . . . . . . . . . . 3-7

3.3.3 Pressure Transducer Readings . . . . . . . . . . . . . . . . . . 3-7

3.4 CHAIN OF CUSTODY $\ldots \ldots \ldots \ldots \ldots \ldots \ldots \ldots \ldots \ldots \ldots$

3.5 TANK U-110 WASTE SURFACE $\ldots \ldots \ldots \ldots \ldots \ldots \ldots$. . . . . . . . . .

4.0 SAMPLE EXTRUSION/SAMPLE PREPARATION . . . . . . . . . . . . 4-1

4.1 DESCRIPTION OF EXTRUSION/SAMPLE: PREPARATION . . . . . . . 4 4-1

4.2 DESCRIPTION OF SEGMENTS . . . . . . . . . . . . 4 4-2

5.0 PHYSICAL AND THERMAL ANALYSIS $\ldots \ldots \ldots \ldots \ldots \ldots \ldots \ldots$. $\ldots \ldots$

5.1 SUMMARY OF PHYSICAL MEASUREMENTS $\ldots \ldots \ldots \ldots \ldots$. $\ldots \ldots$

5.2 THERMAL ANALYSIS $\ldots \ldots \ldots \ldots \ldots \ldots \ldots \ldots \ldots$ 5-3

5.3 PARTICLE SIZE ANALYSIS . . . . . . . . . . . . . . . . 5-10

6.0 CHEMICAL AND RADIOLOGICAL ANALYSIS . . . . . . . . . . . . . 6-1

6.1 CHEMICAL AND RADIOLOGICAL METHODS . . . . . . . . . 6-1

6.2 CHEMICAL AND RADIOLOGICAL DATA SUMMARY . . . . . 6 6-3

6.3 DATA VALIDATION . . . . . . . . . . . . . 6 6-10

6.4 INTERPRETATION OF SEGMENT DATA $\ldots \ldots \ldots \ldots \ldots \ldots \ldots$ 6-12

6.5 INTERPRETATION OF COMPOSITE DATA $\ldots \ldots \ldots \ldots \ldots \ldots 6$. $\ldots \ldots$

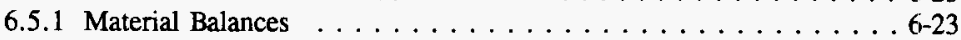

6.5.2 Charge Balances . . . . . . . . . . . . . . 6-27

6.5.3 Comparison of Water, Acid, and Fusion ICP Data . . . . . . . 6 6-28

6.5 .4 Verification of Indicator Analytes . . . . . . . . . . . 6-28

6.6 COMPARISON OF HISTORICAL SAMPLES TO

CURRENT SAMPLES . . . . . . . . . . . . . . . . 6 6 -29 


\section{CONTENTS (continued)}

7.0 STATISTICAL ANALYSIS - CONCENTRATION ESTIMATES OF

TANK U-110 ANALYTES $\ldots \ldots \ldots \ldots \ldots \ldots \ldots \ldots \ldots \ldots \ldots \ldots$

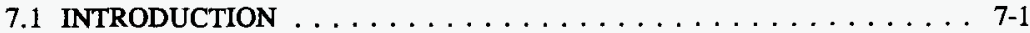

7.2 CONCENTRATION ESTIMATES $\ldots \ldots \ldots \ldots \ldots \ldots \ldots \ldots \ldots .7-2$

7.3 ANALYTES $\ldots \ldots \ldots \ldots \ldots \ldots \ldots \ldots \ldots \ldots \ldots \ldots \ldots \ldots$

7.4 CONCLUSION . . . . . . . . . . . . . . . . . . . . 7-9

7.5 REMAINING STATISTICAL TESTS FOR TANK U-110 $\ldots \ldots \ldots 7-10$

7.6 SUMMARY OF THE STATISTICAL EVALUATION OF

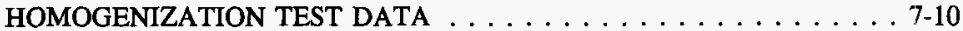

7.7 SUMMARY OF THE COMPARISON BETWEEN A SIMULATED CORE COMPOSITE AND THE CORE COMPOSITE SAMPLE $\ldots \ldots 7-11$

7.8 SUMMARY OF THE STATISTICAL EVALUATION OF THE HOLDING TIME TEST DATA $\ldots \ldots \ldots \ldots \ldots \ldots \ldots \ldots$

7.9 SUMMARY OF THE VARIANCE COMPONENTS $\ldots \ldots \ldots \ldots \ldots \ldots 7-12$

8.0 TWRS PROGRAM ELEMENT CHARACTERIZATION SYNOPSIS $\ldots \ldots \ldots$. 8 - 1

8.1 BULK AVERAGE VERSUS LOCATION SPECIFIC RESULTS $\ldots \ldots \ldots$. . . 8 - 1

8.2 SAFETY PROGRAM CHARACTERIZATION DATA SUMMARY $\ldots \ldots$ 8-1

8.3 RETRIEVAL PROGRAM CHARACTERIZATION

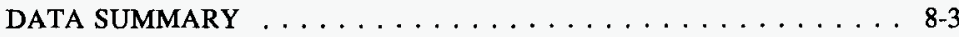

8.4 PRETREATMENT PROGRAM CHARACTERIZATION DATA SUMMARY $\ldots \ldots \ldots \ldots \ldots \ldots \ldots \ldots . \ldots \ldots$

8.5 HWVP CHARACTERIZATION DATA SUMMARY $\ldots \ldots \ldots \ldots \ldots$ 8-4

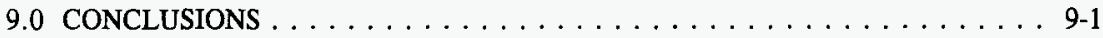

10.0 REFERENCES . . . . . . . . . . . . . . . . . . . . 10-1

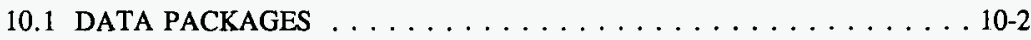

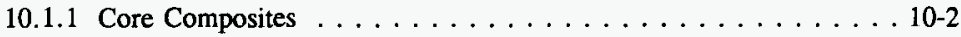

10.1.2 Core Segment Data . . . . . . . . . . . . . 10-3 


\section{LIST OF FIGURES}

2-1 Basic Design of Tank U-110. . . . . . . . . . . . . . 2-2

2-2 Riser Configuration for Tank $U-110 . \ldots \ldots \ldots \ldots \ldots \ldots . \ldots \ldots$. . . . . . . . .

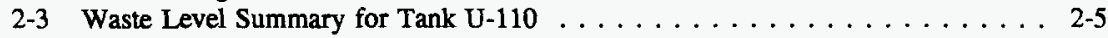

3-1a Core Recovery Summary (Core Sample Locations) . . . . . . . . . . . . . . . 3-4

3-1b Core Recovery Summary (Percent of Expected Volume Recovered) . . . . . . . . 3-5

3-1c Core Recovery Summary (Core Sample Color and Texture) . . . . . . . . . . 3-6

3-2 Hardness of Cores Taken From Tank U-110. . . . . . . . . . . . . . . . . 3-9

3-3 Tank U-110 Surface . . . . . . . . . . . . . . . . . . 3-15

6-1 Water Trend Chart . . . . . . . . . . . . . . . . . 6-17

6-2 Uranium Trend Chart. . . . . . . . . . . . . . . . . . 6-18

6-3 Phosphate Trend Chart. . . . . . . . . . . . . . . . . . . . . 6 6-19

6-4 Aluminum Trend Chart . . . . . . . . . . . . . . . . . . 6-20

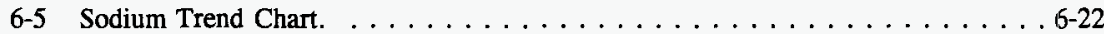




\section{LIST OF TABLES}

2-1 Riser Location Coordinates for Tank U-110 . . . . . . . . . . . . . . . 2-3

2-2 Approximate Chemical Composition of First-Cycle Decontamination (1C) Waste. . . . . . . . . . . . . . . . . . . . . 2-6 2-6

2-3 Approximate Chemical Composition of Bismuth Process Cladding Waste . . . . . 2-7

2-4 Approximate Chemical Composition of REDOX (R) Waste . . . . . . . . . 2-8

2-5 Approximate Chemical Composition of Aluminum Cladding (CWR)

Waste from REDOX Process . . . . . . . . . . . . . . . . . . . . . 2-8

2-6 Key Indicators Expected in Tank U-110 Waste . . . . . . . . . . . . . . . 2-9

2-7 Historical Sampling Data for Tank U-110 . . . . . . . . . . . . . . . . . . 2-10

3-1 Core and Segment Numbering for Tank U-110 (Date Sampled Included Also) . . 3-1

3-2 Chain-of-Custody Summary $\ldots \ldots \ldots \ldots \ldots \ldots$. . . . . . . . . . .

4-1 Sample Description $\ldots \ldots \ldots \ldots \ldots \ldots \ldots \ldots \ldots \ldots$ 4-4

5-1 Physical Properties of Tank U-110 Segments . . . . . . . . . . . 5-1

5-2 Differential Scanning Calorimetry of Tank U-110 Core

Composites - Water Evaporation Occurrence . . . . . . . . . . . . . 5-4

5-3 Thermogravimetric Analysis of U-110 Core

Composites - Water Evaporation Occurrence . . . . . . . . . . . . . . 5 5-6

5-4 Calculation of Latent Heat of Vaporization of Tank U-110 Core Composites . . 5-7

5-5 Differential Scanning Calorimetry of Tank U-110 Core

Composites - Aluminum Hydroxide Dehydration Peak . . . . . . . . . . 5-7

5-6 Thermogravimetric Analysis of Tank U-110 Core

Composites - Aluminum Hydroxide Dehydration Loss . . . . . . . . . . . . 5-8

5-7 Calculation of Heat of Dehydration of Aluminum Hydroxide

of Tank U-110 Core Composites . . . . . . . . . . . . . . . . . 5-9

6-1 Summarized Segment Data for Tank U-110 . . . . . . . . . . . . . . . . 6. 6-4

6-2 Summarized Composite Data for Tank U-110 . . . . . . . . . . . . . 6 6-8

6-3 Trending Chart for Water (Weight \% Water) . . . . . . . . . . . . 6-13

6-4 Trending Chart for Cesium-137 (from Fusion Radiochemistry - uCi/g) . . . . 6-13

6-5 Trending Chart for Uranium (from Fusion Radiochemistry $-\mathrm{ug} / \mathrm{g}$ ) . . . . . . . 6 6-13

6-6 Trending Chart for Fluoride (from Water IC - ug/g) . . . . . . . . . . . . 6-13

6-7 Trending Chart for Nitrate (from Water IC $-\mathrm{ug} / \mathrm{g}$ ) $\ldots \ldots \ldots \ldots \ldots$. . . . . . . .

6-8 Trending Chart for Phosphate (from Water IC - ug/g) . . . . . . . . . . . . 6-14

6-9 Trending Chart for Total Carbon (from Water Digestion - ug/g) . . . . . . . . 6-14

6-10 Trending Chart for Aluminum (from Acid ICP $-\mathrm{ug} / \mathrm{g}$ ) $\ldots \ldots \ldots \ldots$ 6-14

6-11 Trending Chart for Bismuth (from Acid ICP - ug/g) . . . . . . . . . 6-15

6-12 Trending Chart for Iron (from Acid ICP - ug/g) . . . . . . . . . . 6-15 


\section{LIST OF TABLES (continued)}

6-13 Trending Chart for Sodium (from Acid ICP - ug/g) . . . . . . . . . 6-15

6-14 Mass and Charge Balance Summary for Core Composite Data . . . . . . . . . 6-24

6-15 Statistical Summary of Mass and Charge Balance Models for Composite Data . . 5-26

6-16 Historical Samples Versus Current Samples . . . . . . . . . . . . . . . 6-30

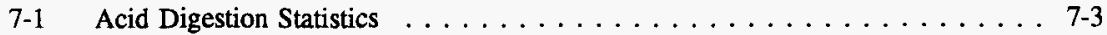

7-2 Acid Digestion, Confidence Limits as Percent of the Mean . . . . . . . 7-4

$7-3 \quad$ KOH Fusion Dissolution Statistics $\ldots \ldots \ldots \ldots \ldots \ldots$ 7-5

7-4 Fusion Dissolution, Confidence Limits as Percent of the Mean . . . . . . . 7-6

7-5 Water Digestion Statistics . . . . . . . . . . . . . . . . . . 7-7

7-6 Water Digestion, Confidence Limits as Percent of the Mean . . . . . . 7-8

7-7 Analytes Measured in Tank $\mathrm{U}-110 \ldots \ldots \ldots \ldots . \ldots . \ldots . . \ldots \ldots$

8-1 Tank U-110 Safety Considerations $\ldots \ldots \ldots \ldots \ldots \ldots \ldots . \ldots \ldots$ 8-2

8-2 Retrieval Program . . . . . . . . . . . . . . . 8-3

8-3 Pretreatment Program . . . . . . . . . . . . . . . . 8-4

8-4 HWVP Process Stream Analytes of Concern . . . . . . . . . . . . 8 8-5

8-5 HWVP Regulatory Operation Analytes of Concern $\ldots \ldots \ldots \ldots$. . . . . . 


\section{LIST OF TERMIS}

1C first-cycle decontamination

AAS Atomic Absorption Spectroscopy Analysis

ANN aluminum nitrate nono hydrate

CL confidence limit

CWR received cladding waste

DSC differential scanning calorimetry

GEA gamma energy analysis

HWVP Hanford Waste Vitrification Plant

IC ion chromatography

ICP inductively coupled plasma

$\mathrm{KOH}$ potassium hydroxide

LL lower limit

NPH normal paraffin hydrocarbon

NSR no sample recovered

R REDOX-concentrated

$R A$ radiological analysis

RCRA Resource Conservation and Recovery Act of 1976

REDOX reduction-oxidation

SNA sample not analyzed

SST single-shell tank

TC total carbon

TGA thermogravimetric analysis

TIC total inorganic carbon

TOC total organic carbon

UA untreated analysis 


\section{TANK CHARACTERIZATION REPORT FOR SINGLE-SHELL TANK 241-U-110}

\subsection{INTRODUCTION}

The characterization report for tank 241-U-110 (U-110) will summarize existing information regarding the waste in the tank in a concise and referenceable format.

\subsection{PURPOSE}

This report investigates the nature of the waste in tank U-110 using historical and current information. When characterizing tank waste, several important properties will be considered. First, the physical characteristics of the waste will be presented, including waste appearance, density, and size of waste particles. The existence of any exotherms in the tank that may present a safety concern will also be investigated. Finally, the radiological and chemical composition of the tank will be presented.

This information will be useful in future operations involving the waste from tank U-110, specifically in the retrieval and downstream processing of the waste.

\subsection{SCOPE}

This report will characterize the tank $U-110$ waste by investigating the processing history surrounding the tank. The events and observations encompassing the sampling of the tank will also be considered. The results of the 222-S Laboratory analysis of the tank waste also will be investigated. The current analytical results will be compared with the expected results from the history of the tank. Finally, a statistical evaluation of the laboratory's performance in analyzing the tank waste will be presented. 
WHC-SD-WM-ER-551 Rev. 0

This page intentionally left blank. 


\subsection{HISTORICAL INFORMATION AND EVALUATION}

Studying the process history of single-shell tank (SST) 241-U-110 (tank U-110) can reveal its physical characteristics as well as the processes that stored waste in the tank. By reviewing these processes and subsequent waste types in more detail, hypotheses can be made about the expected contents of the tank.

\subsection{TANK HISTORY}

Since 1944, underground tanks throughout the Hanford Site's 200 Areas have been used to store radioactive waste. Groups of tanks located together and built at the same time are called tank farms. The U Tank Farm was constructed in 1943 in conjunction with the bismuth phosphate $\left(\mathrm{BiPO}_{4}\right)$ plutonium separation process and was ready for use in 1944 . The U Tank Farm is located in the 200 West Area to service U Plant and is one of the four initial tank farms to be used at the Hanford Site (i.e., B, C, T, and U Tank Farms). Four $208 \mathrm{rn}^{3}$ $(55,000 \mathrm{gal})$ tanks and 12 of the $2,020 \mathrm{~m}^{3}(530,000 \mathrm{gal})$ tanks make up the U Tank Farm; tank U-110 is one of the $2,020 \mathrm{~m}^{3}$ tanks.

The basic design of tank U-110 is shown in Figure 2-1. Tank U-110 is an SST, meaning that the sides and bottom of the tank consist of only one tank wall liner. The tank was constructed of reinforced concrete with a mild steel liner covering the bottom and sides of the tank. The top of the tank is a concrete dome. The tank has a diameter of $22.9 \mathrm{~m}$ $(75 \mathrm{ft})$ and an operating depth of $5.2 \mathrm{~m}(17 \mathrm{ft})$. The tank was buried $2.1 \mathrm{~m}(7 \mathrm{ft} 3 \mathrm{in}$.) underground for shielding purposes.

Tank U-110 is the first member of a cascade connecting tanks U-111 and U-112. By using a cascade, fewer connections need to be made during waste disposal. This method reduces the exposure and handling of the waste to the operators and reduces the chance of a loss of tank integrity from overflow. In the U Tank Farm, by connecting the incoming waste to tank U-110, all three tanks were accessed without having to directly connect the waste to tanks U-111 and U-112. Another advantage of using the cascades is to clarify the waste. The heavier solids settle in the first tank (U-110) and the liquids cascaded on to the other tanks (U-111 and U-112). To make this cascade system work, tank U-110 is slightly elevated above the other two tanks.

For external access to tank $\mathrm{U}-110$, risers are fitted to the tank. These risers are pipes of different diameters-leading into-the tank-dome-from the ground. The riser configuration for tank U-110 is given in Figure 2-2. For the exact location of these risers, refer to Table 2-1. These riser locations are given in both cartesian and polar coordinates. 
Figure 2-1. Basic Design of Tank U-110.

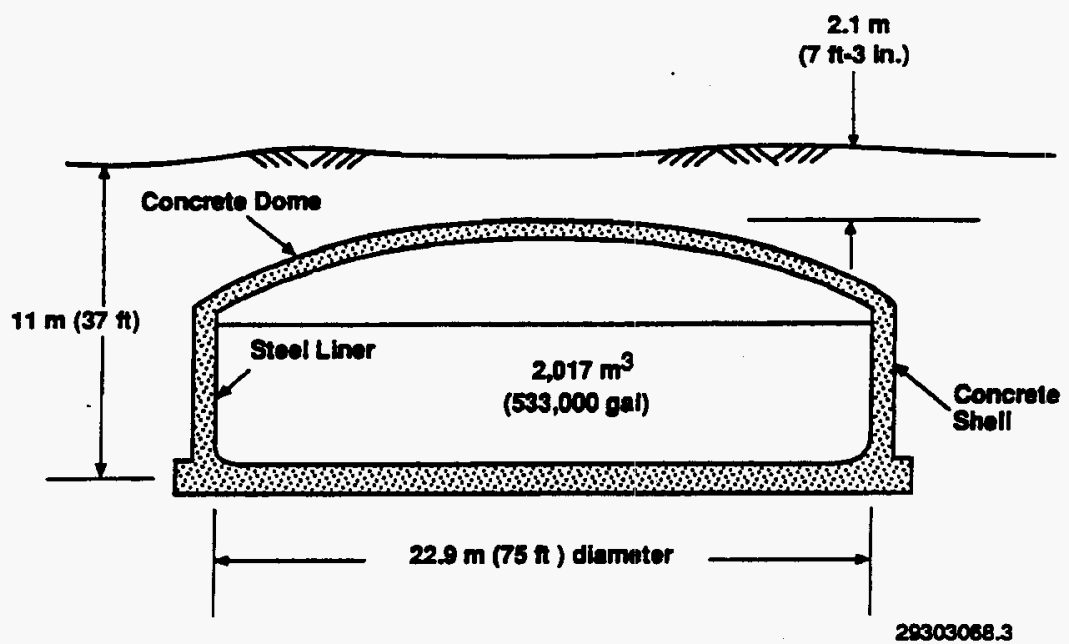

Figure 2-2. Riser Configuration for Tank U-110.

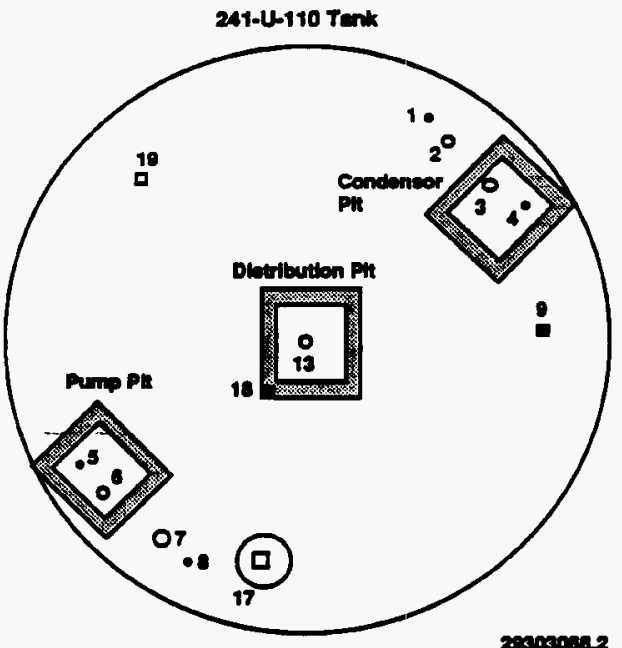


Table 2-1. Riser Location Coordinates for Tank U-110.

\begin{tabular}{|c|c|c|c|c|}
\hline \multirow{2}{*}{ Riser number } & \multicolumn{2}{|c|}{ Cartesian coordinates } & \multicolumn{2}{c|}{ Polar coordinates } \\
\cline { 2 - 5 } & $\mathbf{X}$ (feet) & Y (feet) & Radius (feet) & Angle (degrees) \\
\hline 1 & 18.0 & 27.9 & 33.2 & 57 \\
\hline 2 & 20.1 & 25.8 & 32.7 & 52 \\
\hline 3 & 25.8 & 20.1 & 32.7 & 38 \\
\hline 4 & 27.9 & 18.0 & 33.2 & 32 \\
\hline 5 & -27.9 & -18.0 & 33.2 & -147 \\
\hline 6 & -25.8 & -20.1 & 32.7 & -142 \\
\hline 7 & -20.1 & -25.8 & 32.7 & -128 \\
\hline 8 & -18.0 & -27.9 & 33.2 & -122 \\
\hline 9 & 30.8 & 0.0 & 30.8 & 0.0 \\
\hline 10 & -21.9 & 21.9 & 31.0 & 135 \\
\hline 12 & -11.8 & -28.5 & 30.8 & -112 \\
\hline 13 & 0.0 & 0.0 & 0.0 & N/A \\
\hline Waste inlet & 32.5 & -18.7 & 37.5 & -30 \\
\hline Cascade outlet & -37.5 & 0.0 & 37.5 & 180 \\
\hline
\end{tabular}

Cartesian Coordinats System

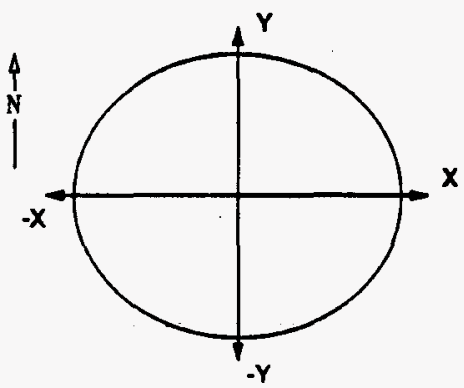

Polar Coordinate System

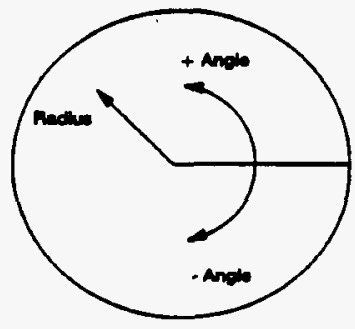


The waste inlet to the tank consisted of horizontal pipes intruding on the interior of the tank wall. Initially, these pipes were part of the tank U-110 cascade configuration. The location for these inlet pipes is also shown in Table 2-1. It is likely that these pipes were used for waste inlet throughout the process history of the tank.

The outlet of the waste from tank U-110 occurs through three possible, different mechanisms. The first type of waste outlet is the cascade overflow nozzle. When the tank receives its full capacity of waste, the waste spills over through this nozzle into tank U-111. The location of this nozzle is shown in Table 2-1. This was the primary mechanism of waste outlet until 1956, when cascading was not used any more in the U-110 to U-112 series of tanks. The second type of waste outlet is via pumps through the risers. Because of the size of the pumps used, only the 1-ft-diameter risers can be used to insert the pumps into the tank. The 1-ft-diameter risers are risers $2,3,6$, and 7 . The use of pumps to remove waste through the risers continued throughout the history of tank U-110. The final method of removing waste, which was made possible in the mid 1970's, is the use of the salt well pump. This pump is located at riser 13.

The document, A History of the 200 Area Tank Farms, discusses the history of tank U-110 (Anderson 1992). Tank U-110 went into service in 1946. It was an active member of a cascade that received first-cycle decontamination $(1 \mathrm{C})$ waste. The $1 \mathrm{C}$ waste is produced in the $\mathrm{BiPO}_{4}$ process and consists of by-products that are coprecipitated from a plutonium-containing solution as well as coating waste from the removal of aluminum. Tank U-110 was full by 1947 and the cascade was full by 1948 . Tank U-110 was idle from 1947 until 1954 when the cascade began to receive REDOX (reduction oxidation)concentrated $(R)$ waste. During this idle time it is very likely that the solids from the $1 \mathrm{C}$ waste began to settle and that the first of the solid sludge began to form. It is also certain that most of the liquids were removed from the tanks through pumping to make room for the $\mathbf{R}$ waste.

The tank received R waste from 1954 until 1956. During this time, tank storage space was gained through self-evaporation of the tank waste. $R$ waste is high-level waste produced during the purification of plutonium in the REDOX process. In 1956, the supernate accumulated in tank U-110 from $R$ waste was sent to various tanks, including C-104, T-106, $\mathrm{U}-109, \mathrm{U}-112$, and U-204.

During 1957, the tank received cladding waste from the REDOX (CWR) Plant. CWR waste was produced by dissolution of aluminum and, in some cases, zircaloy fuel cladding. The tank received very little waste after 1958. Because $\mathbf{N}$ Reactor did not start up until 1963, zircaloy EWR waste is notexpected to be found in the tank.

After receiving CWR waste, the tank sat idle until 1969 when supernate from the tank was sent to tank TX-118. The tank again sat idle three more years until 1972. 
From 1972 until mid-1975, tank U-110 received laboratory waste in small quantities from the 222-S Laboratory. The composition of the laboratory waste is uncertain as is the particular type of laboratory waste stored in tank U-110.

In July 1975 , a leak in tank U-110 was determined to be the cause of slow liquid level drops in the tank accompanied by a slow increase in radioactivity levels in one of the waste tank's monitoring dry wells. By September 1975, the leak in tank U-110 was confirmed (Hanlon 1992). Based on the monitoring that was performed since the leak occurred, it was estimated that 18.9 to $22.7 \mathrm{~m}^{3}(5,000$ to 6,000 gal $)$ of liquid waste leaked into the ground. It was estimated that the leak contained 42 to $50 \mathrm{Ci}$ of ${ }^{137} \mathrm{Cs}$ and 15 to $18 \mathrm{Ci}$ of ${ }^{90} \mathrm{Sr}$ (Burton 1975). The tank was salt well pumped to remove the remaining pumpable liquid and was then removed from service.

Liquid levels in the tank have not been constant since 1975. Although the reasons for the changes in liquid levels are not known, further leaking is still considered a possibility. In 1985, the tank was interim stabilized (Hanlon 1992), and it was decided that all of the SSTs should be interim stabilized. Tank U-110 was one of the first tanks to have been interim stabilized because of its history as a leaker. By 1989 the estimation of the leak was estimated to be $32.2 \mathrm{~m}^{3}$ (8,500 gal) of liquid (Hanlon 1992).

The waste levels of tank U-110 are summarized in Figure 2-3. This diagram shows the historical waste levels for both the solid and supernate waste over the process history of the tank.

Figure 2-3. Waste Level Summary for Tank U-110.

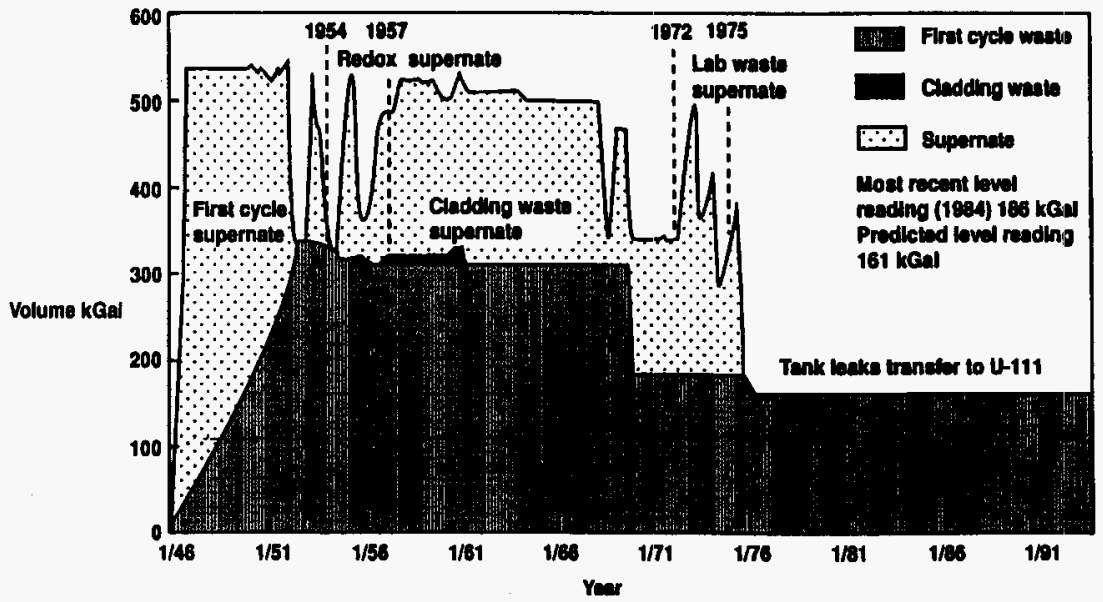

290747.1 


\subsection{EXPECTED TANK CONTENTS}

From the history of tank U-110, the major waste constituents of the tank can be estimated. It is not the objective of this report to determine the concentration of the constituents of the tank from historical records. However, it is important to consider that the records of tank U-110 waste types are incomplete and were kept intermittently. Hence, it is only possible to give approximations of which constituents are expected to be found in the tank. These expected constituents can be compared to the core sampling data results. By making this comparison, the correlation between the data and the records kept may be observed. This comparison offers a method of checking the data for possible errors or inconsistencies.

As mentioned in the tank history, there were three major types of waste that were stored in tank U-110: 1C, R, and CWR wastes (Anderson 1992). Each waste type has key elements or compounds that uniquely distinguish it. When the contents of tank U-110 are analyzed, these key analytes (or "indicators") should be found in the waste in a relatively high abundance compared with other Hanford Site waste tanks. Note that these indicators are not expected to be the only analytes found in the tank or even the analytes found in the greatest abundance. These indicators are discussed throughout the rest of this section.

The first type of waste that tank $\mathrm{U}-110$ received was $1 \mathrm{C}$ waste from the $\mathrm{BiPO}_{4}$ process. An approximate chemical composition of $1 \mathrm{C}$ waste is given in Table 2-2. Cladding waste from the $\mathrm{BiPO}_{4}$ process was mixed with the $1 \mathrm{C}$ waste and comprised about 24 percent of the mixture of these waste streams. The approximate chemical composition of this cladding waste is shown in Table 2-3. Therefore, $1 \mathrm{C}$ waste is more correctly described as a mixture of these two waste types for the purposes of this report. The indicator analytes for this waste type are bismuth, phosphate, aluminum, and fluoride.

Table 2-2. Approximate Chemical Composition of First-Cycle Decontamination (1C) Waste.

\begin{tabular}{|c|c|}
\hline Element//sotope & Concentration mol/L \\
\hline $\mathrm{Bi}^{+3}$ & 0.012 \\
\hline $\mathrm{Ce}^{+4}$ & 0.0002 \\
\hline $\mathrm{Zr}^{+4}$ & 0.0003 \\
\hline $\mathrm{Fe}^{+3}$ & 0.024 \\
\hline $\mathrm{Cr}^{+3}$ & 0.003 \\
\hline$\left(\mathrm{NH}_{\mathbf{J}}{ }^{+}\right.$ & 0.11 \\
\hline $\mathrm{Na}^{+}$ & 2.06 \\
\hline $\mathrm{SiF}_{6}^{-2}$ & 0.031 \\
\hline $\mathrm{PO}_{4}^{-3}$ & 0.276 \\
\hline $\mathrm{NO}_{3}^{-}$ & 1.50 \\
\hline $\mathrm{SO}_{4}^{-2}$ & 0.049 \\
\hline $\mathrm{H}_{2} 0$ & $\mathbf{8 3 . 4 \%}$ \\
\hline & \\
\hline
\end{tabular}


Table 2-3. Approximate Chemical Composition of Bismuth Process Cladding Waste.*

\begin{tabular}{|c|c|}
\hline Chemical & Concentration mol/L \\
\hline $\mathrm{NaAlO}_{2}$ & 1.16 \\
\hline $\mathrm{NaOH}$ & 1.09 \\
\hline $\mathrm{NaNO}_{3}$ & 0.73 \\
\hline $\mathrm{NaNO}_{2}$ & 0.81 \\
\hline $\mathrm{NaSiO}_{3}$ & 0.04 \\
\hline $\mathrm{H}_{2} \mathrm{O}$ & $78 \%$ \\
\hline
\end{tabular}

*This waste was mixed into $1 \mathrm{C}$ waste.

The desired result of the $\mathrm{BiPO}_{4}$ process is to separate plutonium from the uranium in the spent fuel rods. The plutonium is removed from the bulk of the uranium by carrying it on a $\mathrm{BiPO}_{4}$ precipitate out of the uranium solution. In the next step of the $\mathrm{BiPO}_{4}$ process, this precipitate is dissolved and reprecipitated again to further purify the plutonium product. This step is called the first-cycle decontamination step; its waste was very high in $\mathrm{BiPO}_{4}$ and was one of the waste types that were sent to tank U-110. Therefore, bismuth should be one of the key identifiers in the tank waste. Similarly, phosphate is also expected to be one of: the identifiers in the tank.

Because the aluminum cladding waste from the $\mathrm{BiPO}_{4}$ process was mixed with the firstcycle decontamination waste, aluminum should be in abundance (see Table 2-3). During the time that the $\mathrm{BiPO}_{4}$ process was running, the uranium slugs from the 100 Area reactors were clad with aluminum. This aluminum cladding was removed by dissolving with a solution of sodium hydroxide and sodium nitrate. The solution from this coating removal step was high in aluminum. Hence, aluminum is another identifier for the tank waste.

The last indicator from $1 \mathrm{C}$ waste is fluoride. The ion $\mathrm{SiF}_{6}^{-2}$ was added into the first decontamination cycle. It was used to solubilize the fission products, thus increasing the performance of the plutonium separation process. Because of the corrosive nature of fluoride on the waste tanks, it was used as little as possible in Hanford Site operations. Because of its limited use on the Site, fluoride would be a very good indicator analyte for the tank.

According to tank history, $1 \mathrm{C}$ waste was pumped into the cascade for 3 years, which then sat idle for 7 years. This idle period allowed time for the $1 \mathrm{C}$ waste to settle in tank U-110. It should also be noted that tank U-110 was the first member of this cascade, which meant that it probably received more solid waste than the other two tanks during this period. These two factors indicate that tank U-110 received a large amount of solid $1 C$ waste before any other waste type was introduced in the tank. For this reason, it is very likely that $1 \mathrm{C}$ waste will be the predominant waste type in tank U-110.

The second waste type that tank U-110 received was $R$ waste. This waste type is depicted in Table 2-4. The two predominant indicators for this waste type are aluminum and 
chrome. The aluminum comes from a compound commonly referred to as ANN (aluminum nitrate nono hydrate). ANN was added to the dissolved plutonium and uranium feed as a salting agent to enable the plutonium to extract into the organic solvent hexone. This point is important because most of the separations and purifications are made in hexone. As with the $1 \mathrm{C}$ waste, aluminum will be one of the key identifiers from $R$ waste in tank $U-110$.

Table 2-4. Approximate Chemical Composition of REDOX (R) Waste (Anderson 1992).

\begin{tabular}{|c|c|}
\hline Element/Lotope & \multicolumn{1}{|c|}{ Concentration mol/L } \\
\hline $\mathrm{NaAlO}_{2}$ & 1.2 \\
\hline $\mathrm{NaOH}$ & 0.69 \\
\hline $\mathrm{NaNO}_{3}$ & $4: 83$ \\
\hline $\mathrm{Na}_{2} \mathrm{CrO}_{7}$ & 0.066 \\
\hline $\mathrm{Cr}(\mathrm{OH})_{3}$ & 0.045 \\
\hline $\mathrm{Na}_{2}\left(\mathrm{SO}_{4}\right)$ & 0.031 \\
\hline $\mathrm{Fe}(\mathrm{OH})_{3}$ & 0.016 \\
\hline $\mathrm{Uranium}$ & $0.05 \%$ \\
\hline $\mathrm{Pu}-239 / 240$ & $0.04 \%$ \\
\hline
\end{tabular}

Another important step in the purification of plutonium is the oxidation of plutonium from $\mathrm{Pu}$ (III) to $\mathrm{Pu}$ (IV) by using dichromate. Hence, chrome will be another identifier for $\operatorname{tank} U-110$ waste.

The final significant waste type to be added to tank U-110 is CWR from the REDOX process. This waste type is depicted in Table 2-5. This cladding waste is similar to the aluminum cladding waste from the $\mathrm{BiPO}_{4}$ process. In 1963 , zircaloy cladding waste was added to CWR waste with the startup of $\mathrm{N}$ Reactor. Because only a very small amount of waste was stored in the tank after 1958, zircaloy cladding waste is not expected to be found in tank U-110. Again, aluminum will be an identifier for CWR waste in tank U-110.

Table 2-5. Approximate Chemical Cornposition of Aluminum Cladding (CWR) Waste from REDOX Process (Anderson 1992).

\begin{tabular}{|c|c|}
\hline Element/Lsotope & Concentration mol/L \\
\hline $\mathrm{NaAlO}_{2}$ & 1.2 \\
\hline $\mathrm{NaOH}$ & 1.0 \\
\hline $\mathrm{NaNO}_{3}$ & 0.06 \\
\hline $\mathrm{NaNO}_{2}$ & 0.9 \\
\hline $\mathrm{Na}_{2} \mathrm{SiO}_{3}$ & 0.02 \\
\hline $\mathrm{Pu}-239 / 240$ & $0.4 \%$ \\
\hline Uranium & $0.4 \%$ \\
\hline
\end{tabular}


These key identifiers for U-110 tank waste are stimmarized in Table 2-6 and will be addressed later in this report. The comparison betweer the expected tank contents and the laboratory analyzed contents will be performed in Section 6.4.

Table 2-6. Key Indicators Expected in Tank U-110 Waste.

\begin{tabular}{|c|c|c|l|}
\hline $\begin{array}{c}\text { Indicator } \\
\text { (analyte) }\end{array}$ & $\begin{array}{c}\text { Waste } \\
\text { type }\end{array}$ & Process & Use in process \\
\hline $\mathrm{Bi}$ & IC & Bismuth Phosphate & $\begin{array}{l}\text { Precipitates plutonium from uranium. } \\
\text { Decontamination of plutonium. }\end{array}$ \\
\hline $\mathrm{PO4}$ & IC & Bismuth Phosphate & Same as bismuth. \\
\hline $\mathrm{Al}$ & IC & Bismuth Phosphate & Cladding for uranium fuel elements. \\
\hline $\mathrm{F}$ & IC & Bismuth Phosphate & $\begin{array}{l}\text { Solubilize the fission products in the first } \\
\text { decontamination cycle. }\end{array}$ \\
\hline $\mathrm{Cr}$ & $\mathrm{R}$ & REDOX & Oxidation of Pu(III) to Pu(IV) \\
\hline $\mathrm{Al}$ & $\mathrm{R}$ & REDOX & $\begin{array}{l}\text { From ANN (aluminum nitrate-nono hydrate). Used } \\
\text { as a salting agent. }\end{array}$ \\
\hline $\mathrm{Al}$ & $\mathrm{CWR}$ & REDOX & $\begin{array}{l}\text { Aluminum cladding. Same as bismuth phosphate } \\
\text { process. }\end{array}$ \\
\hline
\end{tabular}

The other analytes that are expected to be found in abundance in the tank are sodium and hydroxide because of the large amounts of sodium hydroxide that were poured into the tank to increase the $\mathrm{pH}$ of the tank waste. In addition, some of the sodium hydroxide came from the cladding waste that was stored in the tank. Because large amounts of sodium hydroxide were kept in most of the Hanford Site tanks, neither sodium nor hydroxide will be listed as indicator analytes.

\subsection{HISTORICAL SAMPLING AND CHARACTERIZATION}

The historical sample analyses of the tank waste can help determine the tanks contents. In the history of tank U-110, only two such samples have been taken and analyzed. In 1974, a sample of tank sludge was taken and analyzed. In 1975, a sample of supernate liquid from the tank was also taken and analyzed. In response to the suspected leak, the supernate analysis was performed to determine the composition of the fluids.

Because the sludge sample represents both the soluble and the non-soluble portions of tank U-110 waste, it will provide the more accurate estimate of tank U-110 compounds. In Section 6.0 , a comparison is made of the historical sludge sample to the current analysis.

The composition of these two samples is summarized in Table 2-7. Note that the solid sample analyses are given in micrograms per gram $(\mathrm{mg} / \mathrm{g})$ or microcuries per gram $(\mu \mathrm{Ci} / \mathrm{g})$, whereas the supernate analyses are represented on a per liter basis. 
WHC-SD-WM-ER-551 Rev. 0

Table 2-7. Historical Sampling Data for Tank U-110.

\begin{tabular}{|c|c|c|}
\hline Sample & $?$ & $\mathrm{~T}-5956$ \\
\hline Type of sample & Solid-sludge & Supernate \\
\hline Date & August, 27, 1974 & October 21,1975 \\
\hline Chemical analysis & $(\mathrm{ug} / \mathrm{g})$ & $(\mathrm{ug} / \mathrm{mL})$ \\
\hline $\mathrm{OH}$ & & 1,730 \\
\hline $\mathbf{A l}$ & 135,000 & 41.8 \\
\hline $\mathrm{Fe}$ & 9,710 & \\
\hline $\mathbf{N a}$ & & 5,660 \\
\hline $\mathrm{NO}_{2}$ & 613 & 235 \\
\hline $\mathrm{NO}_{3}$ & 221,000 & 11,800 \\
\hline $\mathrm{CO}_{3}$ & 55,600 & 1,640 \\
\hline $\mathrm{SO}_{4}$ & 8,320 & \\
\hline $\mathrm{PO}_{4}$ & 41,200 & 391 \\
\hline Radionuclides & & $(g / m L)$ \\
\hline Pu & & $3.25 \mathrm{E}-09$ \\
\hline Radionuclides & (uCi/g) & $(\mathrm{uCi} / \mathrm{L})$ \\
\hline${ }^{89,90} \mathrm{Sr}$ & 1,390 & 0.208 \\
\hline${ }^{134} \mathrm{Cs}$ & 1.25 & 0.0176 \\
\hline${ }^{137} \mathrm{Cs}$ & 85.6 & 2.18 \\
\hline${ }^{60} \mathrm{Co}$ & 0.825 & \\
\hline${ }^{125} \mathrm{Sb}$ & 8.45 & \\
\hline${ }^{154} \mathrm{Eu}$ & 1.26 & 0.00293 \\
\hline${ }^{155} \mathrm{Eu}$ & & 0.0121 \\
\hline \multicolumn{3}{|l|}{ Physical Properties } \\
\hline Bulk density (g/mL) & 1.50 & 1.01 \\
\hline Dry particle density $(\mathrm{g} / \mathrm{mL})$ & 2.13 & \\
\hline Percent water & 44.3 & 97.6 \\
\hline Thermal analysis & & No exotherms were observed \\
\hline Appearance & Brown, mud like sludge & Light yellow liquid \\
\hline
\end{tabular}




\subsection{SAMPLING EVENT}

\subsection{NUMBERING SYSTEM OF CORE SAMPLES}

During the last four months of 1989 , eight cores from tank U-110 were sampled. From each of these cores, four segments were taken. On Table 3-1, the numbers of each of these cores and segments are given, along with the dates that the core samples were taken. Throughout this characterization report, the cores and segments will be referred to according to these numbers. This numbering system was implemented in 1989 and is described below.

Table 3-1. Core and Segment Numbering for Tank U-110 (Date Sampled Included Also).

\begin{tabular}{|c|c|c|c|}
\hline $\begin{array}{l}\text { Sequential cone } \\
\text { numbering }\end{array}$ & Dele sompled & Segueat number & Castomer ID \\
\hline \multirow[t]{4}{*}{5} & \multirow{4}{*}{$\begin{array}{l}\text { September } 19 \text { to } \\
\text { November } 7,1989\end{array}$} & 1 & $89-038$ \\
\hline & & 2 & $89-039$ \\
\hline & & 3 & $89-040$ \\
\hline & & 4 & $89-041$ \\
\hline \multirow[t]{4}{*}{6} & \multirow{4}{*}{$\begin{array}{l}\text { November } 13 \text { to } \\
\text { November } 14,1989\end{array}$} & 1 & $89-042$ \\
\hline & & 2 & $89-043$ \\
\hline & & 3 & $89-044$ \\
\hline & & 4 & $89-045$ \\
\hline \multirow[t]{4}{*}{7} & \multirow{4}{*}{$\begin{array}{l}\text { November } 15 \text { to } \\
\text { November } 16,1989\end{array}$} & 1 & $89-046$ \\
\hline & & 2 & $89-047$ \\
\hline & & 3 & $89-048$ \\
\hline & & 4 & $89-049$ \\
\hline \multirow[t]{4}{*}{8} & \multirow[t]{4}{*}{ November 17,1989} & 1 & $89-050$ \\
\hline & & $\overline{2}$ & $89-051$ \\
\hline & & 3 & $89-052$ \\
\hline & & 4 & $89-053$ \\
\hline \multirow[t]{4}{*}{12} & \multirow[t]{4}{*}{ November 29,1989} & 1 & $89-069$ \\
\hline & & 2 & $89-070$ \\
\hline & & 3 & $89-071$ \\
\hline & & 4 & $89-072$ \\
\hline \multirow[t]{4}{*}{13} & \multirow[t]{4}{*}{ November 30, 1989} & 1 & $89-073$ \\
\hline & & 2 & $89-074$ \\
\hline & & 3 & $89-075$ \\
\hline & & 4 & $89-076$ \\
\hline \multirow[t]{4}{*}{14} & \multirow[t]{4}{*}{ December 3, 1989} & 1 & $89-077$ \\
\hline & & 2 & $89-078$ \\
\hline & & 3 & $89-079$ \\
\hline & & 4 & $89-080$ \\
\hline \multirow[t]{4}{*}{15} & \multirow{4}{*}{$\begin{array}{l}\text { December } 4 \text { to } \\
\text { December 6, } 1989\end{array}$} & 1 & $89-081$ \\
\hline & & 2 & $89-082$ \\
\hline & & 3 & $89-083$ \\
\hline & & 4 & $89-084$ \\
\hline
\end{tabular}


In Table 3-1, the first column is the sequential core number. This number uniquely identifies each core sampling event of Hanford Site waste tanks, whether SST or double-shell tank. The numbering for these cores started in August of 1989 and will continue through completion of the core sampling program. The first core for tank $\mathrm{U}-110$ was taken in September of 1989 and was the fifth core taken since the implementation of this numbering system. The second column represents the date that each of the cores was taken. The third column is the segment number. This number is nonsequential and represents only the different segments within one core sample. Each core taken consists of one or more segments, the total of which represents the entire column of waste in the waste tank. The first segment always represents the top segment in a core. These segments are $48 \mathrm{~cm}$ (19 in.) long.

The fourth column is the customer identification number. This number uniquely identifies each segment. At the beginning of every calendar year, all of the segments taken from the tank farms are numbered sequentially. For ar example, the customer identification number for the first segment of core 5 is 89-038. The number means that this is the 38th segment to be sampled in 1989 from the Hanford Site tank farms. At the beginning of every calendar year, this customer identification number is reset to 001 . A number is assigned to every segment, even if there is no recovery.

\subsection{DESCRIPTION OF SAMPLING EVENT}

The core samples from tank U-110 were obtained using a core sampling truck that has sampling equipment mounted on a rotating platform. The truck was positioned over the tank riser corresponding to the desired core sample. The core sampling equipment used to sample tank U-110 worked effectively when recovering liquids or soft sludge but was not as effective when sampling some of the harder material found in the tank. A stainless steel sampler was used to obtain a 48-cm (19-in.)-long and 2.5-cm (1 in.)-diameter core of waste. Unlike current samplers, the sampler used for tank U-110 was not disposable. This sampler was lowered into the tank through a drill string. When tank U-110 was being sampled, the sampler encountered both hard waste and soft sludge. When the sampler encountered the softer layers of the waste, it was pushed through. However, when the sampler encountered one of the hard layers, it was switched to a rotary mode which allowed it to drill through the material. During sampler changeout, normal paraffin hydrocarbons (NPH) were added to the drill string as a hydrostatic fluid to prevent the waste from backing up into the drill string. $\mathrm{NPH}$ is a 10 to 14 hydrocarbon chain and is more commonly referred to as kerosine. As the sampler was passing through the waste, a pressure transducer was used to record the resistance of the-waste on-a-strip chart:-These pressure readings will be considered later. When the sampler had passed $48 \mathrm{~cm}$ (19 in.) through the waste, a spring-actuated rotary valve trapped the sample within the sampler. When the segment was captured within the sampler, it was sealed in a stainless steel liner within a shipping cask to prevent liquid from the sample from being lost. When the sample was received into the shielded receiver, the

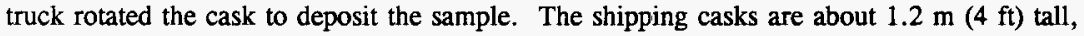


$12.7 \mathrm{~cm}(5 \mathrm{in}$.) in diameter, and have $2.5 \mathrm{~cm}(1 \mathrm{in}$.) of lead shielding. Finally, the sample core and segment number was recorded and the cask was sealed.

The casks were transported to the 222-S Laboratory. To ensure that the samples were sealed and transported without contamination to the 222-S Laboratory, a chain-of-custody form was filled out for each segment. The chain-of-custody forms for the tank U-110 segments will be discussed in Section 3.4.

\subsection{RESULTS OF SAMPLING EVENT}

Sampling event information suggests much about the physical characteristics of the waste in tank U-110; in particular, the following three items will be discussed in this section:

- Recoveries of the different segments

- Problems encountered while drilling (from the chain-of-custody records)

- Pressure transducer readings used to deternnine where the hard layers of waste are located in the waste and how they relate to the process history of the tank.

The sampling of tank U-110 was performed with few problems. The core sampler was switched often between the push and rotary modes, especially in the first two segments of the tank waste, which indicates that a harder layer of waste is at the top of the tank. This inference is confirmed from the pressure transducer readings presented later in this section.

\subsubsection{Segment Recoveries}

The waste recovery for tank U-110 was very poor. There were very few liquid recoveries in any of the samples taken from the tank. The only core sample to receive 80 percent or better recovery on all segments was core 14 from riser 9 . Seven of the 32 segments were not recovered at all. Figure 3-1a through 3-1c shows a core recovery summary for all of the segments sampled from tank U-110. Figure 3-1a is a diagram of an overall view of the tank and the risers from which the core samples were taken. Figure 3-1b gives the percent of the expected volume actually recovered for each segment. Figure 3-1c is a diagram that shows the differences between the color and texture of each of the samples taken.

Because of the poor waste recovery of the sampling effort for tank U-110, both are incomplete segments as well as unresolved segments, the results given later may be biased. The magnitude of this bias cannot be determined. 
Figure 3-1a. Core Recovery Summary (Core Sample Locations).

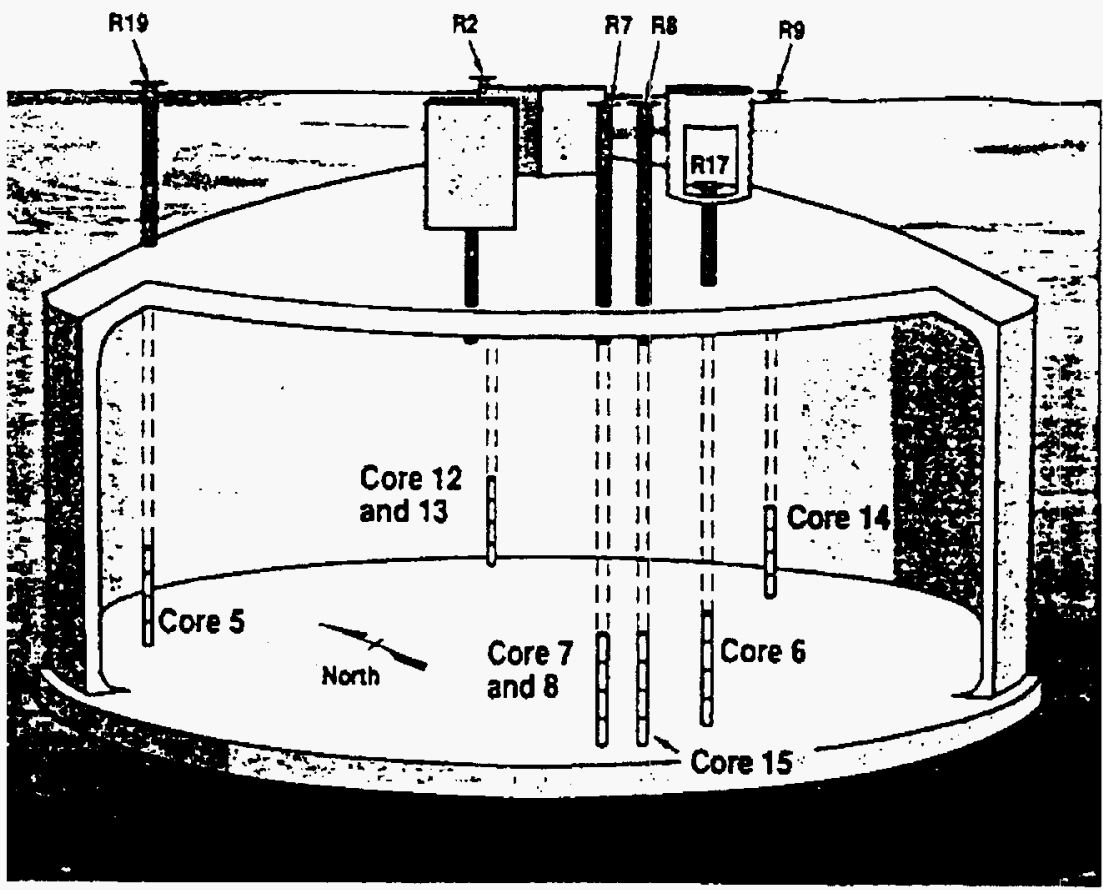


WHC-SD-WM-ER-551 Rev. 0

Figure 3-1b. Core Recovery Summary (Percent of Expected Volume Recovered).

\begin{tabular}{|c|c|c|c|c|c|c|c|c|}
\hline 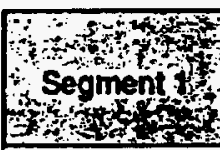 & 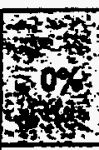 & $\begin{array}{l}x=4 \\
x+0 \% \\
0 \\
0\end{array}$ & $\begin{array}{l}3 \% \\
15 \% \\
20\end{array}$ & $\begin{array}{l}50 \% \\
50 \% \\
50\end{array}$ & $\begin{array}{l}100 \% \\
0\end{array}$ & $\begin{array}{l}25 \% \\
25 \% \\
2 \%\end{array}$ & $\begin{array}{l}0 \% \\
0 \% \\
0\end{array}$ & 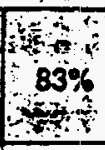 \\
\hline Segment 2 & $0 \%$ & $21 \%$ & $37 \%$ & $80 \%$ & $0 \%$ & $85 \%$ & $27 \%$ & $80 \%$ \\
\hline 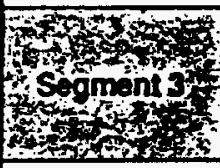 & $\begin{array}{l}2^{2} \\
75 \\
7 \\
7\end{array}$ & 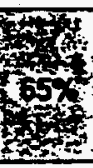 & 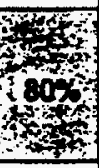 & 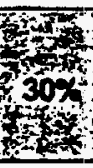 & 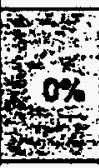 & $\begin{array}{l}4 x \\
70 \% \\
70 \\
30\end{array}$ & 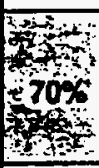 & $\begin{array}{l}6+1 \\
10096 \\
10\end{array}$ \\
\hline Segment 4 & $85 \%$ & $60 \%$ & $40 \%$ & $40 \%$ & $0 \%$ & $15 \%$ & $35 \%$ & $85 \%$ \\
\hline Total Ior Core & $50 \%$ & $45 \%$ & $50 \%$ & $50 \%$ & $8 \%$ & $55 \%$ & $40 \%$ & $90 \%$ \\
\hline $\begin{array}{l}\text { Core } \\
\text { Riser }\end{array}$ & $\begin{array}{c}5 \\
19\end{array}$ & $\begin{array}{c}12 \\
2\end{array}$ & $\begin{array}{c}13 \\
2\end{array}$ & $\begin{array}{l}7 \\
7\end{array}$ & $\begin{array}{l}8 \\
7\end{array}$ & $\begin{array}{c}15 \\
8\end{array}$ & $\begin{array}{c}6 \\
17\end{array}$ & $\begin{array}{c}14 \\
9\end{array}$ \\
\hline
\end{tabular}


Figure 3-1c. Core Recovery Summary (Core Sample Color and Texture).

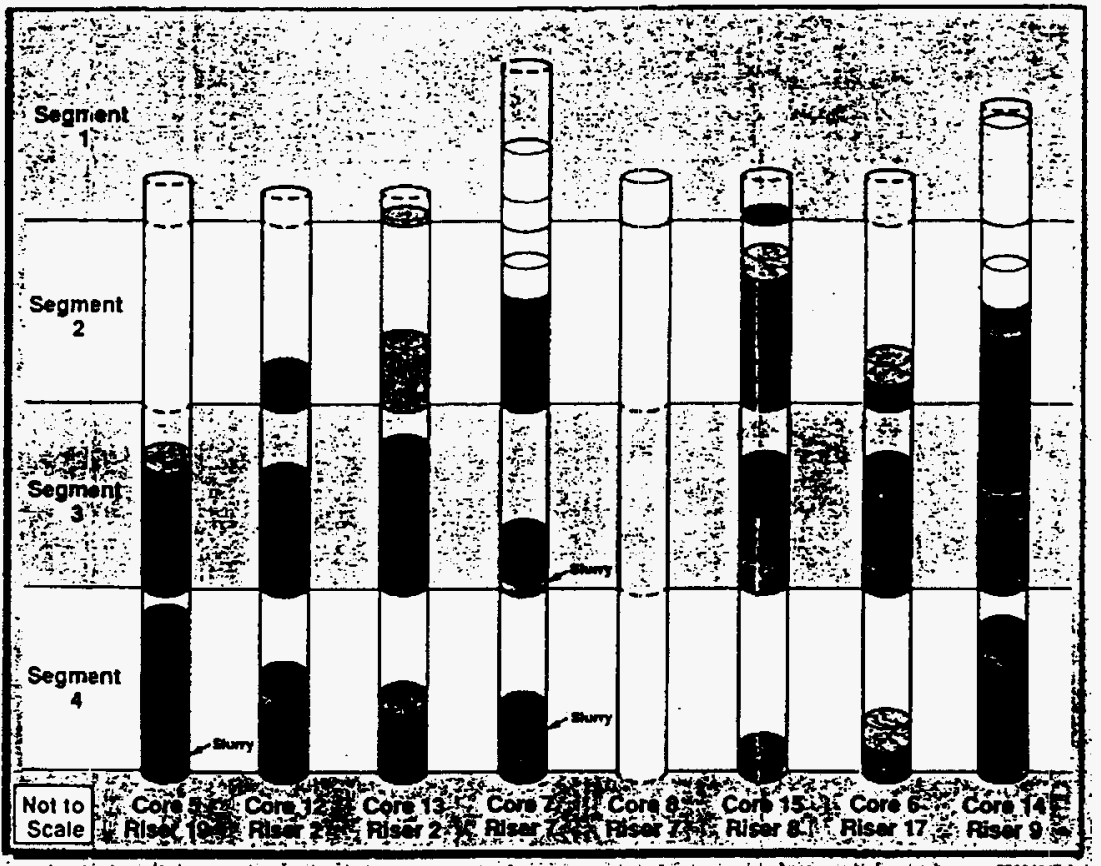




\subsubsection{Problems Encountered While Drilling}

There were a few operational difficulties relating to the recoveries of some of the segments of the tank, which were recorded in the chair-of-custody records (Data Packages 1991). The first of these difficulties was with segment 2 of core 6 . After the sampler haid passed through the waste, the sample did not lock in afterwards because the quadrilatch did not lock into the core barrel. The quadrilatch is a hooked mechanism at the end of the sampler that is used to retrieve the sampler from inside the tank at the end of sampling. This problem was probably the reason for the low recovery (22 percent of a full volume sample) of this sample. This problem also occurred for segments 2 and 3 of core 8 , which probabily accounts for the low ( 8 percent overall) recovery in core 8 .

During the taking of segment 1 of core 7 , the valve on the sampler did not close. The recovery of this sample was 50 percent. There are two likely reasons that a valve would not shut on the sampler. The waste may have been too hard for the valve to shut and/or the shear pin on the pintle rod broke too early. In either case, the sample could still be retrieved if the waste is a sludge. This problem also occurred with the first segment of core 14. Both of these occurrences were at the top of a core sample; thus it is suspected that the reason that the valve did not close was because the waste was too hard.

Chain-of-custody records were not included in the data packages for segment 1 of core 6 , segment 1 of core 12, and segments 1 and 2 of core 13 . All of these segments had either very little recovery or no recovery. It is probable that these segments also encountered some of the problems discussed above during core sampling.

\subsubsection{Pressure Transducer Readings}

A pressure transducer was used to record the resistance of the waste on the sampler. These readings were recorded on strip charts, an example of which is included in Appendix C, Brown and Jensen 1993 (WHC-EP-0643).

The pressure transducer records the pressure such that the lower the reading on the chart, the higher the pressure or resistance of the waste on the sampler. The horizontal line, usually between the 3 and the 4 , is the set point. The varying line on the chart is the pressure reading. When the pressure reaches the set point, the pressure is taken off of the sampler and the sampler stops. The purpose of this set point is to help detect the bottom of the tank or to detect a hard layer of waste. Hence the sampler is only running (either push or rotary mode) when the pressure line is above the set point. When the sampler reaches the end of the estimated segment length; the sampler turns off and the pressure line drops.

From these pressure transducer readings, the hardness of the waste in the core sample can be inferred. Pressure readings do not exactly portray the hardness of the waste encountered, but they do indicate where in the samples the hard layers of waste are located nominally. When the pressure readings are consistently high on the strip chart relative to the set point, the waste is soft and easy to push through. When the pressure reading drops 
towards the set point, the sampler has encountered a harder layer of waste. Sometimes on these readings, the pressure line and the set point meet and the machine has to be turned back on for the sampler to make any progress through the waste. Sometimes the pressure line bounces up and down above the set point. This means that the sampler hit an extremely hard layer of waste material and the sampler took a while to pass through the waste. If the end of the sample is reached where the waste material is this hard, it is likely that the valve will not be able to close.

The core 14 pressure transducer strip chart indicates where the harder layers of material are located under the ninth riser. The first segment is only $10 \mathrm{~cm}$ (4 in.) long. At the top of the segment, the waste is reasonably soft with only a few harder spots of waste. However, a few inches down there is an extremely hard layer of material where the sampler encountered a very high resistance in the waste. This behavior continues throughout the rest of the first segment. The second segment also has a very hard layer in it, which could be: a continuation from the hard layer in the first segment. The material then seems to get softer at the end of the second segment. As can be seen frorn the pressure reading for the third segment, the waste continues to be soft with a few hard spots. The fourth segment, like the third, is fairly soft with intermittent hard spots.

A similar analysis was done for all of the cores taken from tank U-110. The information gained from these pressure readings is summarized in Figure 3-2. From this figure, it can be seen that most of the core samples taken seem to have this hard layer on the top. The only exceptions to this observation are cores 12 and 13 from riser 2 where both of the cores, from top to bottom, are composed of soft waste. The rest of the core samples all have a hard layer in segment 1 and/or in segment 2 .

In two separate instances, two core samples were taken from the same riser location in the tank. The hardness profile of the waste under these risers should be the same for both samples, which allows a check of the correlation of the pressure data between duplicate samples. These duplicate samples are cores 7 and 8 from riser 7 and cores 12 and 13 from riser 2. From Figure 3-2, cores 7 and 8 are similar. When drilling core 7 (the first core from riser 7), a very hard layer was encountered in the first segment. Core 8 also had a hard layer in the first segment but did not meet the resistance that core 7 did. Core 8 also met a little resistance in segment 4 . Overall, the two cores were very similar in their hardness profiles. Cores 12 and 13 were also very similar in their hardness profile in that both were very soft from the top to the bottom of the core. The similarity of these duplicate cores indicates that the pressure transducer readings are an accurate way of establishing where the harder layers of material are in the core.

From the above discussion, it can be seen that there is a hard layer of material that constitutes the upper portion of the waste with the exception of the northeast portion of the tank (riser 2). The poor waste recoveries and the problems encountered while drilling the tank verify that the waste in this tank, particularly at the top, is hard and noncohesive. The lack of liquid in the tank correlates with the process history that the tank has undergone saltwell pumping and interim stabilization. This lack of liquid may also explain the hardness of the waste material in the tank. 
WHC-SD-WM-ER-551 Rev. 0

Figure 3-2. Hardness of Cores Taken From Tank U-110.

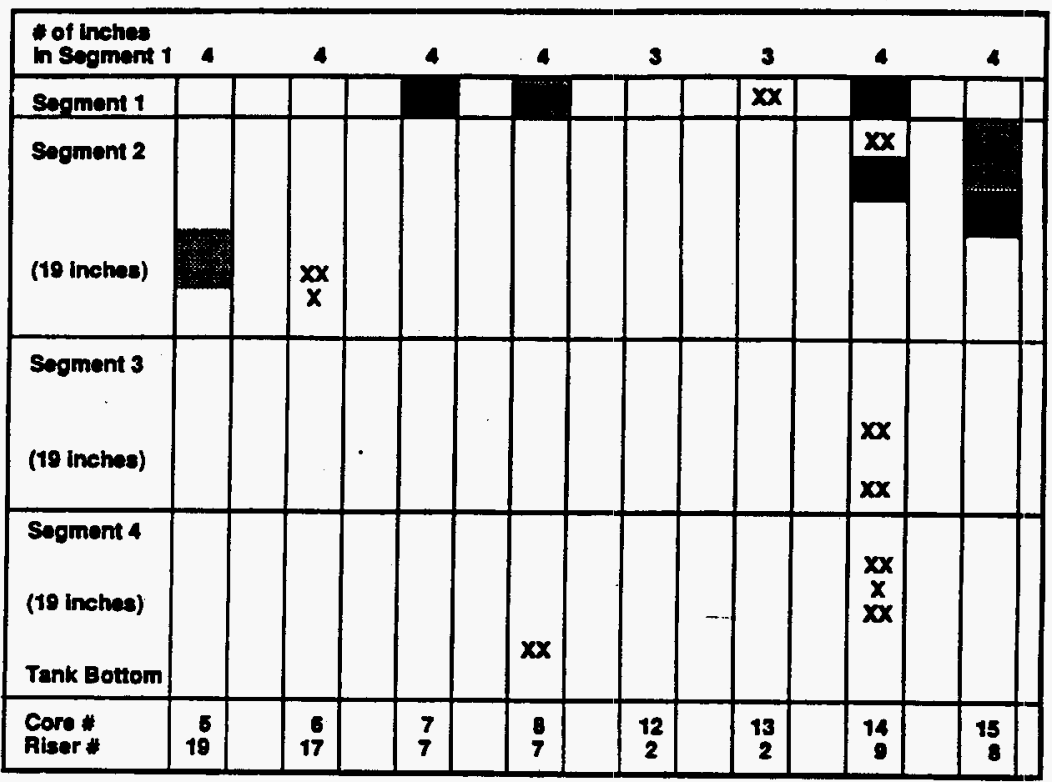

Legend:

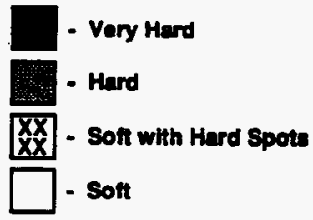

200001.1 


\subsection{CHAIN OF CUSTODY}

A chain-of-custody record was kept during the sampling event for each segment that was sampled (Data Packages 1991). The chain-of-custody form is a 1-page record that is used to make sure that the sample is transported safely and properly from the field to the laboratory and that the correct people are involved in the sampling and transporting of the sample. Information from the chain-of-custody records for tank U-110 is presented in Table 3-2.

At the top of the chain-of-custody record, identification information concerning the tank, riser, and segment numbers are recorded. Also included in this portion of the chain-ofcustody are the shipment, sample, and cask serial numbers for the specific sampling event. The supervisor's name is also given in this section. This information is recorded to ensure that each sample can be uniquely identified from the other samples. The numbering system for samples has already been discussed in Section 3.1.

The chain-of-custody record served several purposes for the sampling and transportation of the tank U-110 samples. The radiation survey is a record of the radiation dose (primarily gamma radiation) that is being emitted from the shipping cask. The dose rates in millirem $/$ hour $(\mathrm{mr} / \mathrm{hr}$ ) are measured from the top, sides, and the bottom of the shipping cask. The last item recorded under the radiation survey data is the smearable contamination. This represents the amount of radiation from waste material that was not sealed within the shipping cask. These dose rates are considered to be unsafe when $100 \mathrm{mr} / \mathrm{hr}$ or more are detected. These measurements are taken both in the field and at the laboratory. In the case of all tank U-110 segments, there were no cask dose rates or smearable contamination that was above the safe limit.

The next section on the chain of custody is the shipment description, which is used to describe the cask and sampler used, as well as the expected contents of the sampler. For tank U-110, 10 to 20 percent liquid sample was expected for each sample; however, when the segments were extruded in the laboratory, very little liquid was recovered from the samples. Another measurement taken in this section of the chain-of-custody record is the dose rate through the drill string. This is the dose in $\mathrm{mr} / \mathrm{hr}$ that is measured through the drill string pipe as the sample is moving through the drill string. This reading was often over $100 \mathrm{mr} / \mathrm{hr}$, especially when there was a full segment in the sampler. Even though this is a high dose rate, it is of little concern because the sampler is transported through the drill string rapidly. Again, there was no information depicted in the shipment description section of the chain-of-custody record that indicated any problems or safety concerns for the sampling of tank U-110.

In the next part of the chain of custody, information about the laboratory tests to be performed as well as comments concerning the sampling event were recorded. As can be seen from the information section on the chain-of-custody record, the characterization plan WHC-EP-0210 for SSTs was used as the statement of laboratory analysis to be performed (Hill et al. 1991). It can also be seen under the comments section that the valve did not close while sampling this segment. The comments concerning sampling difficulties have already been discussed in Section 3.3 . 
Table 3-2. Chain-of-Custody Surnmary. (3 sheets)

\begin{tabular}{|c|c|c|c|c|}
\hline Sample & $\begin{array}{c}\text { Core } 5 \\
\text { Segment } 3\end{array}$ & $\begin{array}{c}\text { Core } 5 \\
\text { Segment } 4 \\
\end{array}$ & $\begin{array}{l}\text { Core } 6 \\
\text { Segment } 2\end{array}$ & $\begin{array}{r}\text { Core } 6 \\
\text { Segment } 3 \\
\end{array}$ \\
\hline Place taken & $\begin{array}{l}\text { U-110 } \\
\text { Riser } 19\end{array}$ & $\begin{array}{l}\text { U-110 } \\
\text { Riser } 19\end{array}$ & $\begin{array}{l}\text { U-110 } \\
\text { Riser } 17\end{array}$ & $\begin{array}{l}\mathrm{U}-110 \\
\text { Riser } 17\end{array}$ \\
\hline Date taken & $11 / 7 / 89$ & $11 / 7 / 89$ & $11 / 13 / 89$ & $11 / 14 / 89$ \\
\hline Date released & $11 / 7 / 89$ & $11 / 7 / 89$ & $11 / 15 / 89$ & $11 / 15 / 89$ \\
\hline Time released & $10: 00$ & $10: 00$ & $09: 20$ & $09: 20$ \\
\hline Sender & B. L. Hall & B. L. Hall & D. C. Hartley & D. C. Hartley \\
\hline Receiver & V. Boyle & V. Boyle & C. M. Seidel & C. M. Seidel \\
\hline Place received & 222-S Laboratory & 222-S Laboratory & 222-S Laboratory & 222-S Laboratory \\
\hline Time received & $10: 40$ & $10: 40$ & $09: 55$ & $09: 55$ \\
\hline $\begin{array}{l}\text { Smearable } \\
\text { contamination }\end{array}$ & $\begin{array}{l}<\text { Det. alpha } \\
<\text { Det. beta }\end{array}$ & $\begin{array}{l}<\text { Det. alpha } \\
<\text { Det. beta }\end{array}$ & $\begin{array}{l}<\text { Det. alpha } \\
<\text { Det. beta }\end{array}$ & $\begin{array}{l}<\text { Det. alpha } \\
<\text { Det. beta }\end{array}$ \\
\hline $\begin{array}{l}\text { Dose rate from } \\
\text { drill string }\end{array}$ & $200 \mathrm{mR} / \mathrm{hr}$ & $100 \mathrm{mR} / \mathrm{hr}$ & $70 \mathrm{mR} / \mathrm{hr}$ & $120 \mathrm{mR} / \mathrm{hr}$ \\
\hline Comments & None & None & None & None \\
\hline Sample & $\begin{array}{l}\text { Core } 6 \\
\text { Segment } 4\end{array}$ & $\begin{array}{c}\text { Core ? } \\
\text { Segment } 1\end{array}$ & $\begin{array}{c}\text { Core 7 } \\
\text { Segment } 2\end{array}$ & $\begin{array}{c}\text { Core } 7 \\
\text { Segment } 3\end{array}$ \\
\hline Place taken & \begin{tabular}{|l} 
U-110 \\
Riser 17
\end{tabular} & $\begin{array}{l}\text { U-110 } \\
\text { Riser } 7\end{array}$ & $\begin{array}{l}\text { U-110 } \\
\text { Riser } 7\end{array}$ & $\begin{array}{l}\mathrm{U}-110 \\
\text { Riser } 7\end{array}$ \\
\hline Date taken & $11 / 14 / 89$ & $11 / 15 / 89$ & $11 / 16 / 89$ & $11 / 16 / 89$ \\
\hline Date released & $11 / 15 / 89$ & $11 / 17 / 89$ & $11 / 17 / 89$ & $11 / 17 / 89$ \\
\hline Time released & $10: 25$ & $13: 00$ & $09: 30$ & 09:30 \\
\hline Sender & D. C. Hartley & D. C. Hartley & D. C. Hartley & D. C. Hartley \\
\hline Receiver & C. M. Seidel & $\begin{array}{l}\text { C. M. Seidel } \\
\end{array}$ & V. Boyle & V. Boyle \\
\hline Place received & 222-S Laboratory & 222-S Laboratory & 222-S Laboratory & 222-S Laboratory \\
\hline Time received & $10: 45$ & $13: 13$ & $10: 00$ & $10: 00$ \\
\hline $\begin{array}{l}\text { Smearable } \\
\text { contamination }\end{array}$ & $\begin{array}{l}<\text { Det. alpha } \\
<\text { Det. beta }\end{array}$ & $\begin{array}{l}<\text { Det. alpha } \\
<\text { Det. beta }\end{array}$ & $\begin{array}{l}<\text { Det. alpha } \\
<\text { Det. beta }\end{array}$ & $\begin{array}{l}<\text { Det. alpha } \\
<\text { Det. beta }\end{array}$ \\
\hline $\begin{array}{l}\text { Dose rate from } \\
\text { drill string }\end{array}$ & $70 \mathrm{mR} / \mathrm{hr}$ & $7 \mathrm{mR} / \mathrm{hr}$ & $120 \mathrm{mR} / \mathrm{hr}$ & $110 \mathrm{mR} / \mathrm{hr}$ \\
\hline Comments & None & $\begin{array}{l}\text { Sampler valve did not } \\
\text { close. White crystals } \\
\text { exposed on end of } \\
\text { sampler. }\end{array}$ & None & None \\
\hline
\end{tabular}


Table 3-2. Chain-of-Custody Surnmary. (3 sheets)

\begin{tabular}{|c|c|c|c|c|}
\hline Sample & $\begin{array}{l}\text { Core } 7 \\
\text { Segment } 4\end{array}$ & $\begin{array}{c}\text { Core } 8 \\
\text { Segment } 1\end{array}$ & $\begin{array}{c}\text { Core 12 } \\
\text { Segment } 2 \\
\end{array}$ & $\begin{array}{c}\text { Core } 12 \\
\text { Segment } 3 \\
\end{array}$ \\
\hline Place taken & $\begin{array}{l}\text { U-110 } \\
\text { Riser } 7\end{array}$ & $\begin{array}{l}\text { U-110 } \\
\text { Riser } 7\end{array}$ & $\begin{array}{l}\mathrm{U}-110 \\
\text { Riser 2 }\end{array}$ & $\begin{array}{l}\text { U-110 } \\
\text { Riser 2 }\end{array}$ \\
\hline Date taken & $11 / 16 / 89$ & $11 / 17 / 89$ & $11 / 29 / 89$ & $11 / 29 / 89$ \\
\hline Date released & $11 / 17 / 89$ & $11 / 20 / 89$ & $11 / 29 / 89$ & $11 / 29 / 89$ \\
\hline Time released & $09: 30$ & $22: 02$ & $20: 45$ & $20: 45$ \\
\hline Sender & D. C. Hartley & D. C. Hartley & D. C. Hartley & D. C. Hartley \\
\hline Receiver & V. Boyle & M. S. Lavarius & $\begin{array}{l}\text { J. C. } \\
\text { Abercrombie }\end{array}$ & $\begin{array}{l}\text { J. C. } \\
\text { Abercrombie }\end{array}$ \\
\hline Place received & 222-S Laboratory & 222-S Laboratory & 222-S Laboratory & 222-S Laboratory \\
\hline Time received & $10: 00$ & $22: 25$ & $21: 19$ & $21: 19$ \\
\hline $\begin{array}{l}\text { Smearable } \\
\text { contamination }\end{array}$ & $\begin{array}{l}<\text { Det. alpha } \\
<\text { Det. beta }\end{array}$ & $\begin{array}{l}<\text { Det. alpha } \\
<\text { Det. beta }\end{array}$ & $\begin{array}{l}<\text { Det. alpha } \\
<\text { Det. beta }\end{array}$ & $\begin{array}{l}<\text { Det. alpha } \\
<\text { Det. beta }\end{array}$ \\
\hline $\begin{array}{l}\text { Dose rate from } \\
\text { drill string }\end{array}$ & $80 \mathrm{mR} / \mathrm{hr}$ & $0.5 \mathrm{mR} / \mathrm{hr}$ & $120 \mathrm{mR} / \mathrm{hr}$ & $130 \mathrm{mR} / \mathrm{hr}$ \\
\hline Comments & None & None & None & None \\
\hline Sample & $\begin{array}{l}\text { Core } 12 \\
\text { Segment } 4\end{array}$ & $\begin{array}{c}\text { Core } 13 \\
\text { Segment } 3\end{array}$ & $\begin{array}{l}\text { Core } 13 \\
\text { Segment } 4\end{array}$ & $\begin{array}{c}\text { Core } 14 \\
\text { Segment } 1\end{array}$ \\
\hline Place taken & $\begin{array}{l}\mathrm{U}-110 \\
\text { Riser } 2\end{array}$ & $\begin{array}{l}\mathrm{U}-110 \\
\text { Riser 2 }\end{array}$ & \begin{tabular}{|l}
$\mathrm{U}-110$ \\
Riser 2
\end{tabular} & $\begin{array}{l}\text { U-110 } \\
\text { Riser } 9\end{array}$ \\
\hline Date taken & $11 / 29 / 89$ & $11 / 30 / 89$ & $11 / 30 / 89$ & $12 / 3 / 89$ \\
\hline Date released & $11 / 29 / 89$ & $12 / 1 / 89$ & $12 / 1 / 89$ & $12 / 4 / 89$ \\
\hline Time released & $21: 52$ & $08: 55$ & $10: 20$ & 09:00 \\
\hline Sender & D. C. Hartley & D. C. Hartley & D. C. Hartley & D. C. Hartley \\
\hline Receiver & J. C. Abercrombie & V. Boyle & V. Boyle & C. M. Seidel \\
\hline Place received & 222-S Laboratory & 222-S Laboratory & 222-S Laboratory & 222-S Laboratory \\
\hline Time received & $22: 07$ & $09: 25$ & $10: 30$ & $09: 21$ \\
\hline $\begin{array}{l}\text { Smearable } \\
\text { contamination }\end{array}$ & $\begin{array}{l}<\text { Det. alpha } \\
<\text { Det. beta }\end{array}$ & $\begin{array}{l}<\text { Det. alpha } \\
<\text { Det. beta }\end{array}$ & $\begin{array}{l}<\text { Det. alpha } \\
<\text { Det. beta }\end{array}$ & $\begin{array}{l}<\text { Det. alpha } \\
<\text { Det. beta }\end{array}$ \\
\hline $\begin{array}{l}\text { Dose rate from } \\
\text { drill string }\end{array}$ & $380 \mathrm{mR} / \mathrm{hr}$ & $200 \mathrm{mR} / \mathrm{hr}$ & $150 \mathrm{mR} / \mathrm{hr}$ & $1.5 \mathrm{mR} / \mathrm{hr}$ \\
\hline Comments & None & None & None & $\begin{array}{l}\text { Valve did not } \\
\text { Close }\end{array}$ \\
\hline
\end{tabular}


Table 3-2. Chain-of-Custody Summary. (3 sheets)

\begin{tabular}{|c|c|c|c|c|}
\hline Sample & $\begin{array}{l}\text { Core } 14 \\
\text { Segment } 2\end{array}$ & $\begin{array}{c}\text { Core } 14 \\
\text { Seggment } 3\end{array}$ & $\begin{array}{l}\text { Core } 14 \\
\text { Segment } 4\end{array}$ & \\
\hline Place taken & \begin{tabular}{|l|} 
U-110 \\
Riser 9
\end{tabular} & $\begin{array}{l}\text { U-110 } \\
\text { Riser } 9\end{array}$ & \begin{tabular}{|l|} 
U-110 \\
Riser 9
\end{tabular} & \\
\hline Date taken & $12 / 3 / 89$ & $12 / 3 / 89$ & $12 / 3 / 89$ & \\
\hline Date released & $12 / 4 / 89$ & $12 / 4 / 89$ & $12 / 4 / 89$ & \\
\hline Time released & 09:00 & 09:00 & 10:03 & \\
\hline Sender & D. C. Hartley & D. C. Hartley & D. C. Hartley & \\
\hline Receiver & C. M. Seidel & C. M. Seidel & R. L. Weiss & \\
\hline Place received & 222-S Laboratory & 222-S Laboratory & 222-S Laboratory & \\
\hline Time received & 09:21 & $09: 21$ & $10: 15$ & \\
\hline $\begin{array}{l}\text { Smearable } \\
\text { contamination }\end{array}$ & $\begin{array}{l}<\text { Det. alpha } \\
<\text { Det. beta }\end{array}$ & $\begin{array}{l}<\text { Det. alpha } \\
<\text { Det. beta }\end{array}$ & $\begin{array}{l}<\text { Det. alpha } \\
<\text { Det. beta }\end{array}$ & \\
\hline $\begin{array}{l}\text { Dose rate from } \\
\text { drill string }\end{array}$ & $200 \mathrm{mR} / \mathrm{hr}$ & $200 \mathrm{mR} / \mathrm{hr}$ & $220 \mathrm{mR} / \mathrm{hr}$ & \\
\hline Comments & None & None & None & \\
\hline Sample & $\begin{array}{c}\text { Core } 15 \\
\text { Segment } 2\end{array}$ & $\begin{array}{l}\text { Core } 15 \\
\text { Segment } 3\end{array}$ & $\begin{array}{l}\text { Core } 15 \\
\text { Segment } 4\end{array}$ & \\
\hline Place taken & $\begin{array}{l}\text { U-1 10 } \\
\text { Riser } 8\end{array}$ & $\begin{array}{l}\text { U-110 } \\
\text { Riser } 8\end{array}$ & $\begin{array}{l}\mathrm{U}-110 \\
\text { Riser } 8\end{array}$ & \\
\hline Date taken & $12 / 4 / 89$ & $12 / 6 / 89$ & $12 / 6 / 89$ & \\
\hline Date released & $12 / 8 / 89$ & $12 / 8 / 89$ & $12 / 8 / 89$ & \\
\hline Time released & $13: 00$ & 13:00 & $13: 33$ & \\
\hline Sender & D. C. Hartley & D. C. Hartley & D. C. Hartley & \\
\hline Receiver & V. Boyle & V. Boyle & V. Boyle & \\
\hline Place received & 222-S Laboratory & 222-S Laboratory & 222-S Laboratory & \\
\hline Time received & $13: 20$ & $13: 20$ & $13: 45$ & \\
\hline $\begin{array}{l}\text { Smearable } \\
\text { contamination }\end{array}$ & $\begin{array}{l}<\text { Det. alpha } \\
<\text { Det. beta }\end{array}$ & $\begin{array}{l}\text { < Det. alpha } \\
<\text { Det. beta }\end{array}$ & $\begin{array}{l}<\text { Det. alpha } \\
<\text { Det. beta }\end{array}$ & \\
\hline $\begin{array}{l}\text { Dose rate from } \\
\text { drill string }\end{array}$ & $140 \mathrm{mR} / \mathrm{hr}$ & $160 \mathrm{mR} / \mathrm{hr}$ & $80 \mathrm{mR} / \mathrm{hr}$ & \\
\hline Comments & None & None & None & \\
\hline
\end{tabular}


Finally, at the bottom of the chain-of-custody record, the sender and receiver of the sample are identified and sign the form to acknowledge their involvement. The sender is the supervisor of the sampling event. The recipient is the person at the laboratory that received the sample. The last information recorded on the chain-of-custody record is whether the seal was intact upon release and upon arrival at the laboratory. The laboratory will not analyze the sample if the seal on the cask was broken enroute to ensure that no contamination of the sample occurred before analysis. The seal number and sample number are also confirmed to ensure that the proper cask was received at the laboratory. There was nothing in this section that was out of the ordinary for tank U-110.

It can be concluded from the chain-of-custody record that, with the exception of the poor sampling recoveries, there was nothing during the sampling of tank U-110 that was irregular or would be considered a safety concern.

\subsection{TANK U-110 WASTE SURFACE}

The waste surface in tank U-110 is shown in Figure 3-3, which is a montage of photographs taken at different locations on the tank waste surface. These photographs were taken through riser 7, the observation port riser. These photographs were taken in July 1979.

Several of the riser locations are easily identified by the pipes rising vertically from the waste surface. These risers are identified in the color figure. While riser 13 is actually in the center of the tank, in the figure it appears to be far back in the tank. Note that not all of the existing risers have a pipe connected from the riser to the waste.

The most distinguishing feature on the waste surface is the mound of waste located on the right hand side of the diagram, next to the tank wall. This mound is located directly under the cascade inlet pipes. The mound is semi-spherical in shape and has a radius of approximately $1.8 \mathrm{~m}(6 \mathrm{ft})$. This mound is also identified in the color figure. 
WHC-SD-WM-ER-551 Rev. 0

Figure 3-3. Tank U-110 Surface.




WHC-SD-WM-ER-551 Rev. 0

This page intentionally left blank. 


\subsection{SAMPLE EXTRUSION/SAMPLE PREPARATION}

\subsection{DESCRIPTION OF EXTRUSION/SAMPLE PREPARATION}

The casks containing the tank U-110 samples were received from the transport vehicle at the 222-S Laboratory. Sample segments were stored in the casks in the laboratory until they were extruded from the sampler. The time that the samples were stored (holding time) was kept to a minimum because of the uncertainty of the effects of the NPH hydrostatic fluid on the sample. Another reason that the holding time was minimized was regulatory concerns about potential sample degradation. For these reasons, it was desirable to have holding times of no greater than 2 weeks. The holding times of the U-110 samples ranged from being extruded on the same day as core sampling to 2 months after core sampling. Six of the eight cores were extruded within 10 days of sampling. The fourth segment of core 15 was extruded one month after sampling. The other two cores (cores 12 and 13) were extruded two months after sampling. In some instances, holding times for some of the core 14 samples were prolonged to perform a statistical study of the effect of holding time on sample analysis. Statistical holding time studies for this tank will be considered later in this report to determine if prolonged holding times affected the quality of the data or altered the nature of the waste in any degree.

The samples were stored in the laboratory until the $1 \mathrm{E}-2$ hot cell in the 222-S Laboratory became available for extrusion. The sampler was removed from the shipping cask directly into the hot cell. All work in this hot cell was done remotely, with the operator being behind $60 \mathrm{~cm}(2 \mathrm{ft})$ of lead glass. The sample was loaded onto the mechanical horizontal extruder. The sample was removed through the use of a piston that: was placed at the top of the sample. The sampler was then forced toward the piston, thereby extruding the sample, bottom end first, onto a metal tray. During this extrusion, the sample remained in place and the sampler moved away from the tray. The sample and any liquids were collected on a metal tray. Penetrometer readings of the sample were then taken of the sample. Penetrometer measurements will be discussed in Section 5.1. Next, the mass of the segment and the approximate length were recorded. From this information the bulk densities of the segments were estimated (see Section 5.1).

Only five segments had $10 \mathrm{ml}$ or more of fluid in them. The most fluid recorded in a segment was $38 \mathrm{ml}$ from core 7 segment 2 . All other segments had less than $10 \mathrm{ml}$ of fluid, if any. The fluid that was observed from the tank U-110 samples was a clear liquid. This liquid was probably NPH from the sampling operations. The true nature of the liquid is not known as a liquid analysis was not performed. Because of the lack of liquid found in the tank, a description of the liquids extruded from the tank samples will not be given. The amount of liquid recorded for each section will be given in Section 5.1. At the completion of this extrusion, photographs were taken and a brief description of each segment was written by the technician. The samplers used for tank U-110 sampling were removed and decontaminated for further use in tank farm sampling. 
After the solid sample was extruded onto the metal tray, the sample was moved to the $1 \mathrm{E}-1$ hot cell. At this stage of sample preparation, any samples that needed to be taken before homogenization of the sample were taken. These smaller samples were taken as aliquots. These aliquot samples were taken by pushing a small, open metal tube into the segment. The pre-homogenization analyses samples that were taken from tank U-110 segments were to be used for particle size analysis and volatile organic analysis. The particle size analysis was performed and will be considered in the next chapter. The volatile organic analysis for tank U-110 samples was never performed and will not be considered in this report. This is because NPH was used in the tank which is likely to cause a high bias in the organic analysis results.

The next step in the sampling preparation process for tank $U-110$ segments was homogenization of the segments. Homogenization of tank U-110 segments was performed in an apparatus called a stomacher, a bag with paddles inside of it that mixes the segment in a motion similar to kneading bread. When the tank U-110 sample homogenization was planned, the nature of the waste was not known and the samples were expected to be of a soft consistency, like peanut butter. It was discovered that the consistency of the samples: actually ranged from soft to clay-like to hard and crusty. The stomacher is only mildly effective at mixing hard waste if the waste is noncohesive (or brittle). The stomacher is ineffective with cohesive material, whether it is hard or claylike and is most effective with soft, wet, sludge-like waste.

Most of the laboratory analysis on the tank U-110 samples were performed on these homogenized samples. These analyses are considered in Sections 5.0 and 6.0 of this report.

Some of the analyses that were performed on tank $U-110$ samples were performed on core composites. A core composite is a single representation of the entire core. These core composites were created by mixing portions of each segment of a core together. These portions were proportional by weight to the recovery for each segment of that core. The analyses of these core composites will also be considered in Sections 5.0 and 6.0. When all of the homogenizing and compositing activities were completed, the aliquots for analysis were taken. Remaining samples for tank U-110 were archived and are now stored at the 222-S Laboratory.

\subsection{DESCRIPTION OF SEGMENTS}

Through the photographs and written descriptions of the extruded segments, the physical characteristics of the waste can be better understood. Photographs of each segment were taken after the extrusion of the segment. Sample photographs taken from core 14 segments 1 through 4 are given in Appendix C, Brown and Jensen 1993, to show the appearance of the waste. Also, the technician who extruded the samples wrote a brief description of each, and these descriptions are shown in Table 4-1 (Data Packages 1991). These written descriptions give important points that cannot be easily seen in the photographs, such as the liquid content appearance and the texture appearance of the waste material. Some segments were extruded that had no recovery or such a small recovery that 
they were not analyzed. Descriptions of these segments are not recorded in the data packages. These segments are labeled samples not analyzed (SNA) in Table 4-1. The material from these segments was still used in the core composites.

As can be seen on the photographs, the segments are shown on the metal tray in the hot cell. The yellow appearance of some of the photographs indicates that the photographs are being taken through $60 \mathrm{~cm}(2 \mathrm{ft})$ of lead glass. The segments range in color from white to light or dark brown to black. The segments are generally crumbly but sometimes still hold the cylindrical shape of the sampler. The extruder and sampler are to the right of the segments in these photographs. A wooden block either underneath or to the left of the segment shows the segment number. A color strip is placed under the segment to aid in deciphering the segment color. The only segment to be fully recovered is core 14 segment 3 , and this photograph may be used as a reference for a comparison of the recoveries of the segments.

From the photographs and the written descriptions of the segments, it is apparent that the color, texture, and hardness of the waste is very heterogeneous throughout the tank. The absence of any appreciable amount of liquid, as well as the problems trying to push through the waste while sampling, seem to give evidence to a tank full of dry, crumbly waste. However, while looking at the photographs of the samples and reading the sample descriptions, a large portion of the waste, especially towards the bottom, is soft and even sludge like. Even the pressure transducer readings indicate that the hardest portion of the tank to sample was at the top, and that the bottom two segments of the tank were usually easy to push the sampler through.

A vertical stratification of the layers was observed from the sample photographs and descriptions. This stratification represents a general pattern throughout the tank and is indistinct in some segments. While a brief description of these strata are given below, it is important to understand that the tank is very heterogeneous and that every core is still very unique in its appearance.

The first and most distinctive layer is at the top of the waste in the tank. The predominant feature of this layer is its bright white color. This layer is approximately 10 to $40 \mathrm{~cm}$ (5 to 14 in.) thick and is observed in segment 1 and the top of segment 2 of some of the samples. Because segment 1 was not retrieved in every sample, it is uncertain if this layer exists throughout the whole tank. Photographs of this white layer can be seen in core 7 segment 1 , core 7 segment 2 , core 8 segment 1 , core 14 segment 1 , and in core 14 segment 2 (only core 14 photos are shown in Appendix C, Brown and Jensen 1993). It can be seen in Figure 3-2 that these segments were very hard during sampling. This white layer was described generally as being noncohesive to semicohesive, granular, and chalk-like. The only exception to this description is for core 14 segment 2 , where the white layer was described as being runny. It is evident that one compound in the process waste was lighter in color than the others and may have produced this layer. This possibility will be discussed in the next chapter of this report. 
Table 4-1. Sample Description. (2 sheets)

\begin{tabular}{|c|c|c|c|c|}
\hline Core & Segment 1 & Segment 2 & Segment 3 & ScBmoil 4 \\
\hline 5 & NSR & NSR & $\begin{array}{l}\text { Sample was dark brown. Slightly } \\
\text { moist on the lower surface drying } \\
\text { towards top. The last } 2.5 \mathrm{~cm} \\
\text { (1 in.) of the top was dry and } \\
\text { crumbly with no cohesion. }\end{array}$ & $\begin{array}{l}\text { Bottom } 10 \mathrm{~cm} \text { ( } 4 \text { in.) very sof, runny, } \\
\text { light to modium brown. Middle, } \\
\text { firmer, medium brown. Top } 13 \mathrm{~cm} \\
(5 \text { in.) rubbery firm (very cohesive), } \\
\text { black in color. Small hard chunks } \\
\text { (possible crystals) of approximately } \\
0.32 \mathrm{~cm}(1 / 8 \mathrm{in} \text { ) in diameter. }\end{array}$ \\
\hline 6 & NSR & $\begin{array}{l}\text { Sample was semi-cohesive at } \\
\text { bottom, grading to crumbly at top. } \\
\text { Sample was uniform brown color. }\end{array}$ & $\begin{array}{l}\text { Sample graded upward from } \\
\text { medium brown to dark brown. } \\
\text { Sample was firm and cohesive } \\
\text { throughout, and there was a } 5.1 \mathrm{~cm} \\
(2 \text { in.) segment at bottom which } \\
\text { was separated from the rest of the } \\
\text { segment by a small void. }\end{array}$ & $\begin{array}{l}\text { Sample was dark brown grading to } \\
\text { medium brown. Granular looking } \\
\text { throughout. Moist and sticky } \\
\text { appearance at bottom grading toward } \\
\text { crumbly and noncohesive at top. }\end{array}$ \\
\hline 7 & $\begin{array}{l}20 \mathrm{~cm}(8 \text { in.) of white semi to } \\
\text { noncohesive material. Color } \\
\text { changed from bright white at } \\
\text { bottom to brownish white at top. } \\
\text { Bottom } 8 \text { to } 10 \mathrm{~cm}(3 \text { to } 4 \text { in.) } \\
\text { semi-cohesive. Broke into } \\
\text { chunks. }\end{array}$ & $\begin{array}{l}\text { Bottom } 31 \mathrm{~cm}(12 \mathrm{in.}) \text { of sample } \\
\text { dark gray to black in color, } \\
\text { cohesive and firm. Top } 8 \mathrm{~cm} \\
\text { ( } 3 \text { in.) white, granular, enumbly, } \\
\text { noncohesive with a slippery/slimy } \\
\text { texture. }\end{array}$ & $\begin{array}{l}\text { Sample dark brown except for } \\
\text { bottom chunk (which is medium } \\
\text { brown) of about } 2 \mathrm{~cm} \mathrm{(3/4} \mathrm{in.).} \\
\text { Granular terture thmughout the } \\
\text { sample with some hard bits. Semi- } \\
\text { cohesive consistency with bottom } \\
\text { portion much less cohesive than } \\
\text { rest of sample, almost runny. }\end{array}$ & $\begin{array}{l}\text { Dark brown bottom } 5.1 \mathrm{~cm} \text { ( } 2 \text { in.) the } \\
\text { rest of the sample is medium brown. } \\
\text { Surface of bottom } 5.1 \mathrm{~cm}(2 \mathrm{in} \text {.) } \\
\text { apperered moist, the rest was dry and } \\
\text { very crumbly. Sample broke into } 6 \\
\text { segments, } 2.5 \mathrm{~cm}(1 \text { in.) or more in } \\
\text { length. Middle section had a complete } \\
\text { lack of cohesiveness. Hard chunks } \\
\text { found in crumbly part. }\end{array}$ \\
\hline 8 & $\begin{array}{l}\text { Hard, white crumbly solids. } \\
\text { Material is more sticky than } \\
\text { previous cores. }\end{array}$ & NSR & NSR & NSR \\
\hline 12 & NSR & $\begin{array}{l}\text { Very dark brown in color with } \\
\text { firm crumbles of solids. At least } \\
\text { one } 0.6 \mathrm{~cm}(1 / 4 \text { in.) chunk of } \\
\text { solid found in the sample. There } \\
\text { was insufficient material to } \\
\text { perform a penetrometer test. }\end{array}$ & $\begin{array}{l}\text { Very dark brown color with firm } \\
\text { solids. }\end{array}$ & $\begin{array}{l}\text { Light brown solids. Upper } 3.8 \mathrm{~cm} \\
(1.5 \mathrm{in} .) \text { medium brown, and very } \\
\text { smooth in appearance. }\end{array}$ \\
\hline
\end{tabular}


Table 4-1. Sample Description. (2 sheets)

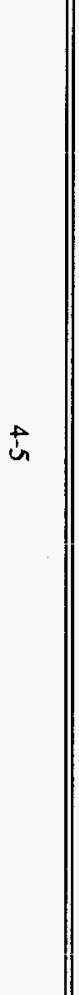

\begin{tabular}{|c|c|c|c|c|}
\hline Core & Segment 1 & Segment 2 & Segment 3 & Segmeat 4 \\
\hline 13 & SNA & SNA & $\begin{array}{l}\text { Sample was dark brown with firm } \\
\text { solids. During the early stage of } \\
\text { extrusion, no sample but "air" } \\
\text { noted leaking from the sample } \\
\text { valve. }\end{array}$ & $\begin{array}{l}\text { The solid sample was slightly soft. } \\
\text { Most of the solids were dark brown. } \\
\text { The top } 2.5 \mathrm{~cm} \text { ( } 1 \text { in.) was chocolate } \\
\text { brown. Some hard "chunks" noted in } \\
\text { the solids. }\end{array}$ \\
\hline 14 & $\begin{array}{l}\text { Extrusion completed only after } \\
\text { hammering free. White chalk like } \\
\text { sample of approximately } 25 \mathrm{~cm} \\
(10 \mathrm{in} .) \text {, only } 10 \mathrm{~cm}(4 \mathrm{in} .) \\
\text { expected. }\end{array}$ & $\begin{array}{l}\text { Top } 10 \mathrm{~cm} \text { ( } 4 \text { in.) granular and } \\
\text { white in color. Remainder of } \\
\text { segment firm and dark brown to } \\
\text { black at the bottom } 7.6 \mathrm{~cm} \text { ( } 3 \text { in.). } \\
\text { White portion of segment runny } \\
\text { but semi-cohesive. }\end{array}$ & $\begin{array}{l}\text { Very dark brown solids. Darker } \\
\text { towards top segment. Firm, broke } \\
\text { into } 2.5 \mathrm{~cm} \text { ( } 1 \text { in.) sections on } \\
\text { extrusion. Surface "greases" with } \\
\text { some clear liquid in tray around the } \\
\text { valve assembly. Somewhat } \\
\text { crumbly when taking volatile } \\
\text { organic analysis. }\end{array}$ & $\begin{array}{l}\text { Top } 5 \text { cm ( } 2 \text { in.) brown, the rest dark } \\
\text { brown. Somewhat crumbly, but moist } \\
\text { texture throughout. Clear liquid, } \\
\text { some lost through valve. Small hard } \\
\text { solids found in the sample. }\end{array}$ \\
\hline 15 & NSR & $\begin{array}{l}\text { Fibrous strands at very bottom } \\
\text { segment. Bottom } 36 \mathrm{~cm} \text { ( } 14 \mathrm{in} \text { ) } \\
\text { dark brown, cohesive but crumbly } \\
\text { looking. Evidence of twisting the } \\
\text { sample. Upper } 5 \mathrm{~cm} \text { ( } 2 \text { in.) very } \\
\text { crumbly, lighter brown material. } \\
\text { Many small "rocks" in the sample. }\end{array}$ & $\begin{array}{l}\text { The bottom } 7.6 \mathrm{~cm} \text { ( } 3 \text { in.) is light } \\
\text { brown cohesive. The next } 25 \text { to } \\
28 \mathrm{~cm}(10 \text { to } 11 \text { in.) is very dark } \\
\text { brown/black cohesive. Material is } \\
\text { very dry and crumbly at the top. } \\
\text {. }\end{array}$ & $\begin{array}{l}\text { Sample was chocolate brown solids. } \\
\text { Cohesive. Sample was extruded into } \\
\text { jar. }\end{array}$ \\
\hline
\end{tabular}

NSR $=$ No sample recovered.

SNA = Sample not analyzed. 
The second layer comprises most of the waste in the tank. This layer encompasses the second and third segments of the core samples plus part of the top of the fourth segment in many instances (see Appendix C, Brown and Jensen 1993). This layer is dark brown to black in color and ranges in consistency. The layer is more moist and cohesive than the first layer and many of the segments retrieved in this layer held the cylindrical shape of the sampler upon extrusion. Many of the segments in this layer, particularly the ones that held their shape, were described by the technician as having the consistency of clay. This layer ranges from being smooth to granular and also ranges from being cohesive to being noncohesive.

The last layer is made up of the last segment of the core (or the bottom portion of the last segment in some instances) and represents the waste closest to the bottom of the tank (see Appendix C, Brown and Jensen 1993). The fourth segment extruded from every core was always crumbly and in some instances also contained runny or sludge-like material. This layer was also a lighter brown than the second layer. In many of the fourth segments, small solid chunks of material were observed, which is expected because any solid waste would have settled to the bottom of the tank. It is possible that the chemical makeup of this bottom layer and the middle layer are similar and that the major difference between the two is the settling of the larger solids that has occurred in the bottom layer.

Again, this description of the stratification of the waste in tank U-110 offers only an approximate description of the waste. For a specific description of the waste at one of the sampling locations in the tank, refer to the photograph and the written description of the sample appearance of the segments. For more specific physical characteristics of the waste, refer to Section 5.1 of this report or to the physical tests section of the data packages. 


\subsection{PHYSICAL AND THERMAL ANALYSIS}

\subsection{SUMMARY OF PHYSICAL MEASUREMENTS}

Records of the physical tests that were performed on the tank U-110 segments are found in the segment data packages (Data Packages 1991). The information concerning these tests is summarized in Table 5-1.

Table 5-1. Physical Properties of Tank U-110 Segments.

\begin{tabular}{|c|c|c|c|c|c|c|c|}
\hline Core & Segment & $\begin{array}{l}\text { Sample } \\
\text { length } \\
\text { (in.) }\end{array}$ & $\begin{array}{l}\text { Calc } \\
\text { volume } \\
\text { (in.?) }\end{array}$ & Mass (g) & $\begin{array}{c}\text { Density } \\
(\mathrm{g} / \mathrm{cc})\end{array}$ & $\begin{array}{l}\text { Drainable } \\
\text { liquid (mL) }\end{array}$ & $\begin{array}{c}\text { Penetrometer } \\
\text { (Bbs/in.') }\end{array}$ \\
\hline 5 & 3 & 14.0 & 11.0 & 187 & 1.04 & $<10$ & 18.8 \\
\hline 5 & 4 & 16.0 & 12.5 & N/A & -- & $<10$ & 3.8 \\
\hline 6 & 2 & 5.0 & 3.93 & 102 & 1.59 & None & 13.8 \\
\hline 6 & 3 & 13.0 & 10.2 & 203 & 1.22 & 10 & 6.3 \\
\hline 6 & 4 & 6.0 & 4.71 & 139 & 1.80 & 25 & 10.0 \\
\hline 7 & 1 & 8.0 & 6.28 & 183 & 1.78 & None & 10.0 \\
\hline 7 & 2 & 15.0 & 11.8 & 282 & 1.46 & 38.3 & 12.2 \\
\hline 7 & 3 & 6.0 & 4.70 & 118 & 1.53 & $<10$ & 9.4 \\
\hline 7 & 4 & 6.0 & 4.70 & 149 & 1.93 & $<10$ & 1.8 \\
\hline 12 & 2 & 4.0 & 3.14 & 91 & 1.77 & 20 & N/A \\
\hline 12 & 3 & 12.0 & 9.40 & 155 & 1.00 & $<10$ & 10.0 \\
\hline 12 & 4 & 10.1 & 7.90 & 192 & 1.48 & $<10$ & 11.3 \\
\hline 13 & 3 & 15.0 & 11.8 & 221 & 1.14 & $<10$ & 13.8 \\
\hline 13 & 4 & 8.0 & 6.28 & 151 & 1.46 & $<10$ & N/A \\
\hline 14 & 1 & 10.0 & 7.85 & 192 & 1.50 & None & 2.5 \\
\hline 14 & 2 & 15.0 & 11.8 & 269 & 1.39 & $<10$ & 25.0 \\
\hline 14 & 3 & 19.0 & 14.9 & 341 & 1.40 & 25 & 7.5 \\
\hline 14 & 4 & 15.0 & 11.8 & 314 & 1.62 & N/A & 3.1 \\
\hline 15 & 2 & 16.0 & 12.6 & 262 & 1.27 & $<10$ & 15.0 \\
\hline 15 & 3 & 13.0 & 10.2 & 219 & 1.30 & None & 6.3 \\
\hline 15 & 4 & 3.0 & 2.36 & 51 & 1.31 & None & N/A \\
\hline \multirow{4}{*}{\multicolumn{2}{|c|}{$\begin{array}{l}\text { Statistical } \\
\text { Summary }\end{array}$}} & Mean & & & 1.46 & & 9.8 \\
\hline & & S.D. & & & 0.24 & & 5.7 \\
\hline & & $\operatorname{Max}$ & & & 1.93 & & 25.0 \\
\hline & & Min & & & 1.00 & & 1.8 \\
\hline
\end{tabular}


From the physical measurements performed on the extruded samples, the densities of the segments may be estimated. This density estimation is shown on Table 5-1. The first two columns in this table provide distinctive identification for each segment. In column three, the length of the segment is given. In column four, the volume of the segment is approximated by the laboratory using the segment length. The complete segment length is $48 \mathrm{~cm}$ (19 in.) but because the core recovery for this tank was poor, the length of the segment was frequently less than $48 \mathrm{~cm}$ (19 in.). The volume is calculated by multiplying the length of the segment by the cross-sectional area of the segment. Because the crosssectional diameter of a segment is constant $(2.5 \mathrm{~cm}[1$ in.]), the approximate volume is dependant only upon the segment length. This information was obtained from the data packages for tank U-110. Column five gives the mass of the segment (in grams) as measured in the laboratory. In column six, the densities of the segments are calculated where data is available by dividing the mass of the segment by the volume of the segment and then adjusting to the units of $\mathrm{g} / \mathrm{cc}$. As the statistical data shows, the density from core to core varies from 1.0 to $1.9 \mathrm{~g} / \mathrm{cc}$, with an average of $1.5 \mathrm{~g} / \mathrm{cc}$.

This wide range is most likely because the method of volume approximation did not: account for any porous spaces in the waste material. Any liquid within the porous spaces of the bulk of the waste is called interstitial liquid. Depending on the porosity of the waste at any location, the bulk density of a sample will vary. Another consideration that needs to be made with this type of volume measurement is the void space created when a sample crumbles upon extrusion. For these reasons, a wide range in the densities of the samples must be expected.

For the best approximation of the dry density of the waste matter, void space should be neglected as far as possible, which is done by choosing the highest density (approximately $1.9 \mathrm{~g} / \mathrm{cc}$ ) because these samples most likely had the least amount of void space. For the apparent or wet density, the average density should be chosen which is $1.5 \mathrm{~g} / \mathrm{cc}$.

Column seven shows the volume of the liquid drained from the sample upon extrusion. Drainable liquid was mentioned in Section 4.0.

In the last column, the penetrometer reading is given, which measures the ability to penetrate the waste. It is a measurement of the force required to overcome the resistance of the waste to the penetrometer. A high penetrometer reading would indicate that the waste is either hard or very cohesive. A low penetrometer reacling would indicate that the waste is soft or very friable. This information could be used in future sampling efforts when the waste will need to be penetrated by a sampler. There is no recognizable pattern in the penetrometer readings from segment to segment or from core to core.

At the bottom of Table 5-1 is a brief section showing basic statistical information for both the density and the penetrometer readings. 


\subsection{THERMAL ANALYSIS}

The thermal analyses of tank U-110 consists of differential scanning calorimetry (DSC) analysis and thermogravimetric (TGA) analyses. These analyses were performed on the core composite data only (Data Packages 1991). The primary purpose of these thermal analyses is to detect any exothermic reactions that may occur in the waste material at an elevated temperature. The presence of an uncontrollable exothermic reaction would be a safety concern, especially if for any reason the waste was exposed to elevated temperatures that could trigger such a reaction. No exothermic reactions were found during the thermal analysis of tank U-110 samples, as is shown by the thermal analysis portion of the data for the core composite data packages.

The second reason for performing these analyses is for the detection of any other reactions or change of state that may aid in characterizing the sample. The DSC analysis is used to detect reactions or changes of state that involve the release or absorption of energy at elevated temperatures. The TGA analysis is used to detect the loss of gaseous matter (usually water) from reactions or changes of state at elevated temperatures.

For an example of the DSC and TGA analysis plots on the tank U-110 core composites, refer to Appendix D, Brown and Jensen 1993. The plots are useful in understanding the thermal analysis of the core samples.

In DSC analysis, the heat that is either released or absorbed by the substance is measured while the substance is exposed to a linear increase in temperature. That is to say, $\mathrm{dT} / \mathrm{dt}=$ Constant (where $\mathrm{T}=$ Temperature, and $\mathrm{t}=$ Time). In the case of every core composite, $\mathrm{dT} / \mathrm{dt}=20^{\circ} \mathrm{C} /$ minute. While the substance is being heated, a gas (air in this case), is passed over the waste material to remove any gases being released.

A plot has been made of all of the DSC events (see Appendix D, Brown and Jensen 1993). The $X$-axis is temperature in degrees Celsius. Because $d T / d t$ is constant, this axis is also proportional to the running time of the DSC. The Y-axis is heat absorbed or evolved per time in millicalories/second. The upward pointing peaks on these plots represent either an endothermic reaction or an endothermic change of state. A downward pointing peak, however, would represent an exothermic reaction or change of state. The computer that produced these plots was capable of calculating the heat absorbed in calories per gram of sample during the endothermic reaction or change of state. This calculation was done by integrating the area under the curve of the peak and adjusting the units of the heat produced to calories. The computer then divided this result by the mass of the sample. The technician that performed these analyses calculated the heat absorbed for each significant endothermic peak. No exothermic peaks were observed in any of the DSC plots for the tank U-110 core composites. The DSC event (as well as the TGA event) was run from $50{ }^{\circ} \mathrm{C}$ to $500{ }^{\circ} \mathrm{C}$.

Although the DSC scans differ for each core composite, the number of endothermic peaks is noticeably similar for each core as well as the general temperature for these endothermic occurrences. Most of the DSC plots have two endotherms, one at about $100{ }^{\circ} \mathrm{C}$ and the other at about $330^{\circ} \mathrm{C}$. Two hypotheses will be made to account for these two 
peaks. The first of these peaks probably represents the evaporation of the water in the sample. This is an endothermic change of state and is represented by equation 1:

$$
\mathrm{H}_{2} \mathrm{O}_{(n)} \rightarrow \mathrm{H}_{2} \mathrm{O}_{(8)}^{\uparrow} \quad\left(100^{\circ} \mathrm{C}\right)
$$

The second of these peaks is suspected to be the dehydration of aluminum hydroxide to alumina and gaseous water as per equation 2 :

$$
\mathrm{Al}(\mathrm{OH})_{3(s)} \rightarrow \frac{1}{2} \mathrm{Al}_{2} \mathrm{O}_{3(s)}+\frac{3}{2} \mathrm{H}_{2} \mathrm{O}_{(s)} \uparrow \quad\left(300^{\circ} \mathrm{C}\right)
$$

The location (temperature) of the water peak and aluminum hydroxide peak are summarized in Tables 5-2 and 5-5, respectively. These tables show the core composite number and the bottle number. The bottle number is at unique identification for each core composite sample that underwent thermal analysis. The start temperature, end temperature, and the maximum temperature are recorded on the table and are given in degrees Celsius. The last row on this table is the computed value of the heat supplied to the sample in calorie/gram.

Table 5-2. Differential Scanning Calorimetry of Tank U-110 Core Composites - Water Evaporation Occurrence.

\begin{tabular}{|c|c|c|c|c|c|}
\hline $\begin{array}{c}\text { Core } \\
\text { composite } \\
\text { number }\end{array}$ & Bottle number & \multicolumn{5}{|c|}{ Water evaporation peak } \\
\cline { 3 - 6 } (Celsius) & To (Celsius) & $\begin{array}{c}\text { Maximum at } \\
\text { temperature } \\
\text { (Celsius) }\end{array}$ & $\begin{array}{c}\text { Heat supplied } \\
\text { to sample } \\
\text { (mcal/sec) }\end{array}$ \\
\hline 5 & B000307 & 55 & 142 & 104 & 91.6 \\
\hline 6 & B000296 & 55 & 155 & 107 & 92.8 \\
\hline 7 & B000268 & 55 & 102 & 78 & 24.5 \\
\hline 8 & B000293 & & No water peak recorded \\
\hline 12 & B000357 & 55 & 165 & 117 & 132 \\
\hline 13 & B000347 & 55 & 190 & 125 & 139 \\
\hline 14 & B000327 & 54 & 133 & 80 & 11.2 \\
\hline 15 & B000328 & 55 & 140 & 98 & 69.5 \\
\hline
\end{tabular}


To confirm the above hypotheses, the latent heat of vaporization of water of equation 1 and the heat of reaction of equation 2 will be calculated later in this section and will be compared to the theoretical values of these heats. The second of these hypotheses was examined by the technician who performed the DSC. Pure (dry) aluminum hydroxide was analyzed by DSC under the same conditions as the tank waste samples and then compared to the second peak of the core composite from core 8 . Core 8 was chosen for this comparison because it consists only of the white layer characteristic to segment 1 . Because of an error in the compilation of the data packages, this comparison is found in the thermal analysis of core 5. Note that for such a comparison to be made, this particular graph was normalized. A normalized analysis shows the heat on a per gram basis so that both the pure aluminum. hydroxide sample and the core 8 sample can be compared graphically despite their sample: weights. This comparison is shown in Appendix D, Brown and Jensen 1993. The units on this table are therefore mcal/sec/gram. As can be seen in Appendix D, Brown and Jensen 1993, the two peaks are very similar, thus suggesting that the endotherm encountered in the tank U-110 samples at about $330{ }^{\circ} \mathrm{C}$ is indeed the dehydration of aluminum hydroxide. Note that core composite $\# 8$ showed no water peak and cores 12 and 13 showed no aluminum hydroxide peak, which is expected because cores 12 and 13 had no recovery in segment 1 .

In TGA analysis, the sample is weighed while being heated. As with the DSC, a computer printout of the TGA analysis event was produced for each core composite. Again, $\mathrm{dT} / \mathrm{dt}$ is constant and the X-axis is representative of the running time of the analysis as well as the temperature increase of the sample during analysis. The $\mathrm{Y}$-axis represents the weight percent of the sample and is effectively unitless. As with the DSC, air is passed over the sample during heating. Any decrease in the mass of the sample represents a loss of gasecous matter from the sample either through evaporation or through a reaction with gas phase products.

As with the DSC results, there are two noticeable gas losses in the TGA printouts. The first (probably due to the evaporation of water, see equation 1) occurs at about $100{ }^{\circ} \mathrm{C}$. The second (probably due to the dehydration of aluminum hydroxide, see equation 2) occurs at about $330^{\circ} \mathrm{C}$. All eight core composites showed a water loss on the TGA but cores 12 and 13 did not show an aluminum hydroxide loss.

Although these two water vapor loss events create a definite pattern on the DSC and TGA plots, they are not necessarily the only events where a gas is being released. There is still a negative slope on the TGA plots between the water dehydration loss and the aluminum hydroxide dehydration loss as well as after the aluminum dehydration loss. This release of mass of the sample may be caused by the loss of water of hydration of other various hydrates that may be found in the waste. Other events that most likely occurred during these analyses that were not necessarily recognizable on the DSC and TGA plots are the melting and decomposition of sodium nitrate and sodium nitrite. Sodium nitrate melts at $307^{\circ} \mathrm{C}$ and decomposes at $380{ }^{\circ} \mathrm{C}$. Likewise, sodium nitrite melts at $271^{\circ} \mathrm{C}$ and decomposes at $320^{\circ} \mathrm{C}$. These temperatures occur at the usual temperature range at which aluminum hydroxide dehydrates and could be hidden easily on the plots. 
The losses observed for water evaporation and for aluminum hydroxide dehydration are summarized in Tables 5-3 and 5-6, respectively. (In these tables, the percent loss [gaseous water in both instances] is the difference between a start value and an end value.) The starting point is the temperature at which the event started to occur and as a percent of remaining sample weight at the same point. The end event is presented in the same manner. The overall mass loss of the water (in both tables) is calculated as the difference between the start and end points. This number represents the percentage of the mass of the water evaporated (or dehydrated in the case of aluminum hydroxide) from the bulk of the sample and released to the air.

Table 5-3. Thermogravimetric Analysis of U-110 Core Composites - Water Evaporation Occurrence.

\begin{tabular}{|c|c|c|c|c|c|c|}
\hline \multirow{2}{*}{$\begin{array}{l}\text { Core } \\
\text { composite } \\
\text { number }\end{array}$} & \multirow[b]{2}{*}{$\begin{array}{l}\text { Bottle } \\
\text { number }\end{array}$} & \multicolumn{5}{|c|}{ Water evaporation peak } \\
\hline & & $\begin{array}{l}\text { From } \\
\text { (Celsius) }\end{array}$ & $\begin{array}{l}\text { From } \\
\text { (percent) }\end{array}$ & $\begin{array}{l}\text { To } \\
\text { (Celsius) }\end{array}$ & $\begin{array}{l}\mathrm{To} \\
\text { (percent) }\end{array}$ & $\begin{array}{l}\text { Percent } \\
\text { weight } \\
\text { (percent) }\end{array}$ \\
\hline 5 & B000307 & 43 & 100 & 136 & 88.9 & 11.1 \\
\hline 6 & B000296 & 42 & 100 & 134 & 81.0 & 19.0 \\
\hline 7 & $\mathrm{~B} 000268$ & 43 & 100 & 125 & 94.0 & 5.98 \\
\hline 8 & B000298 & 43 & 100 & 149 & 94.3 & 5.67 \\
\hline 12 & $\mathrm{~B} 000357$ & 42 & 100 & 149 & 70.9 & 29.1 \\
\hline 13 & $\mathrm{~B} 000347$ & 42 & 100 & 135 & 70.9 & 29.1 \\
\hline 14 & $\mathrm{~B} 000327$ & 43 & 100 & 130 & 81.6 & 18.4 \\
\hline 15 & B000328 & 43 & 100 & 125 & 85.6 & 14.4 \\
\hline
\end{tabular}

By dividing the heat absorbed by the sample to evaporate the water (from the DSC water peak) by the fraction water loss (from the TGA water loss), the latent heat of vaporization for water of the samples may be calculated (see Table 5-4). A sample of these calculations is performed in Appendix D, Brown and Jensen 1993. In the last column of that table, the experimental latent heat of vaporization is compared to the value recorded in Perry's Chemical Engineers' Handbook (Perry 1984). Five out of seven of the values calculated are within 25 percent error of the theoretical value. Because of the high possibility of instrumental error associated with these readings, these values are considered close enough to confirm that this particular endotherm is indeed water evaporation. Because of the moisture of these samples, this is a reasonable hypotheses. 
Table 5-4. Calculation of Latent Heat of Vaporization of Tank U-110 Core Composites.

\begin{tabular}{|c|c|c|c|c|c|c|}
\hline $\begin{array}{c}\text { Core } \\
\text { composite } \\
\text { number }\end{array}$ & $\begin{array}{c}\text { Bottle } \\
\text { number }\end{array}$ & $\begin{array}{c}\text { Heat } \\
\text { supplied/ } \\
\text { sarmple mass } \\
\text { (cal/g) }\end{array}$ & $\begin{array}{c}\text { Mass } \\
\mathrm{H}_{2} \text { O/mass } \\
\text { sample } \\
\text { (percent) }\end{array}$ & $\begin{array}{c}\text { Latent heat of } \\
\text { vaporization } \\
\left.\text { (cal/g } \mathbf{H}_{2} \mathbf{0}\right)\end{array}$ & $\begin{array}{c}\text { Percent error } \\
\text { from } \\
\text { theoretical } \\
\text { value }\end{array}$ \\
\hline 5 & B000307 & 91.6 & 11.1 & 825 & 52.6 \\
\hline 6 & B000296 & 92.8 & 19.0 & 488 & 9.74 \\
\hline 7 & B000268 & 24.5 & 5.98 & 410 & 24.1 \\
\hline 8 & B000293 & & No water peak recorded & \\
\hline 12 & B000357 & 132 & 29.1 & 454 & 15.9 \\
\hline 13 & B000347 & 139 & 29.1 & 478 & 11.6 \\
\hline 14 & B000327 & 11.2 & 18.4 & 60.9 & 88.7 \\
\hline 15 & B000328 & 69.5 & 14.4 & 482 & 10.9 \\
\hline Theoretical
\end{tabular}

Table 5-5. Differential Scanning Calorimetry of Tank U-110 Core Composites Aluminum Hydroxide Dehyclration Peak.

\begin{tabular}{|c|c|c|c|c|c|}
\hline $\begin{array}{c}\text { Core } \\
\text { composite } \\
\text { number }\end{array}$ & Bottle number & $\begin{array}{c}\text { From } \\
\text { (Celsius) }\end{array}$ & To (Celsius) & $\begin{array}{c}\text { Maximum } \\
\text { temperature } \\
\text { (Celsius) }\end{array}$ & $\begin{array}{c}\text { Heat of Al(OH) } \\
\text { decomposition } \\
\text { (cal/g) }\end{array}$ \\
\hline 5 & B000307 & 250 & 350 & 299 & 13.3 \\
\hline 6 & B000296 & 270 & 370 & 326 & 50.7 \\
\hline 7 & B000268 & 238 & 357 & 313 & 170 \\
\hline 8 & B000293 & 280 & 360 & 320 & 245 \\
\hline 12 & B000357 & & No Al(OH) $)_{3}$ peak recorded \\
\hline 13 & B000347 & & No Al(OH) $)_{3}$ peak recorded \\
\hline 14 & B000327 & 267 & 361 & 313 & 102 \\
\hline 15 & B000328 & 230 & 340 & 299 & 19.2 \\
\hline
\end{tabular}


Table 5-6. Thermogravimetric Analysis of Tank U-110 Core Composites - Aluminum Hydroxide Dehydration Loss.

\begin{tabular}{|c|c|c|c|c|c|c|}
\hline \multirow{2}{*}{$\begin{array}{l}\text { Core } \\
\text { composite } \\
\text { number }\end{array}$} & \multirow[b]{2}{*}{$\begin{array}{l}\text { Bottle } \\
\text { number }\end{array}$} & \multicolumn{5}{|c|}{$\mathrm{Al}(\mathrm{OH})_{3}$ dehydration peak } \\
\hline & & $\begin{array}{l}\text { From } \\
\text { (Celsius) }\end{array}$ & $\begin{array}{c}\text { From } \\
\text { (percent) }\end{array}$ & $\begin{array}{c}\text { To } \\
\text { (Celsius) }\end{array}$ & $\begin{array}{l}\text { To } \\
\text { (percent) }\end{array}$ & $\begin{array}{l}\text { Percent } \\
\text { weight } \\
\text { (percent) }\end{array}$ \\
\hline 5 & B000307 & 235 & 87.9 & 348 & 85.1 & 2.83 \\
\hline 6 & B000296 & 226 & 80.3 & 348 & 75.7 & 4.53 \\
\hline 7 & B000268 & 227 & 93.5 & 350 & 78.4 & 15.1 \\
\hline 8 & B000298 & 240 & 94.3 & 368 & 67.8 & 26.5 \\
\hline 12 & B000357 & \multicolumn{5}{|c|}{ No $\mathrm{Al}(\mathrm{OH})_{3}$ peak recorded } \\
\hline 13 & B000347 & \multicolumn{5}{|c|}{ No $\mathrm{Al}(\mathrm{OH})_{3}$ peak recorded } \\
\hline 14 & B000327 & 240 & 81.1 & 349 & 70.8 & 10.3 \\
\hline 15 & B000328 & 244 & 84.8 & 329 & 80.7 & 4.10 \\
\hline
\end{tabular}

Similarly, by dividing the heat absorbed by the sample to dehydrate the aluminum hydroxide by the fraction of aluminum hydroxide that dehydrated, the heat of reaction of equation 2 is calculated for the core composites (see Table 5-7). The fraction of aluminum hydroxide that dehydrated is not a measurable amount but can be calculated from a molar balance using the mass fraction of gaseous water released. A sample of these calculations is performed in Appendix D. In the last row of this table, the calculated heat of reaction is compared with the theoretical heat of reaction. The theoretical heat of reaction is calculated in Appendix D with heat of formation values and specific heat values from Perry's Chemical Engineers' Handbook (Perry 1984). Four out of six of the values calculated are within 25 percent error of the theoretical value.

Besides experimental error, one possible cause of error is that the aluminum hydroxide dehydration reaction is probably still occurring to a lesser extent even after its normal reaction temperature. This error is suspected because the slope of the TGA graph after the aluminum hydroxide endotherm is still slightly negative, meaning that there is still gas being released. A similar error exists for evaporation of the interstitial water in the sample. That is, the interstitial water within a large sample of waste takes time to diffuse to the surface of the waste upon evaporation. If diffusion is slow, the water will not leave the waste sample until well after its boiling point of $100^{\circ} \mathrm{C}$. To overcome this problem, the sample should be crushed before the TGA analysis. Another possible source of error is the gas that passes over the sample. Ideally, a less reactive gas such as nitrogen should be used to remove the gases released during the thermal analysis. Because air was used, there is always a possibility of some minor oxidation reaction affecting the results. 
Table 5-7. Calculation of Heat of Dehydration of Aluminum Hydroxide of Tank U-110 Core Composites.

\begin{tabular}{|c|c|c|c|c|c|c|c|}
\hline $\begin{array}{l}\text { Core } \\
\text { composite } \\
\text { number }\end{array}$ & $\begin{array}{l}\text { bottle } \\
\text { tupaber }\end{array}$ & $\begin{array}{l}\text { Heat } \\
\text { masplied/aamplo }(\mathrm{cal} / \mathrm{B})\end{array}$ & $\begin{array}{l}\text { Mass } \\
\text { Heo/mass } \\
\text { sample } \\
\text { (percent) }\end{array}$ & $\begin{array}{l}\text { Mass } \\
\text { Al(OHD } 3 / \text {, } \\
\text { mast sample } \\
\text { (percent) }\end{array}$ & $\begin{array}{l}\text { Latent heat of } \\
\text { dofydration } \\
(\mathrm{cat} / \mathrm{B} \mathrm{H} 2 \mathrm{O})\end{array}$ & $\begin{array}{l}\text { Porcent error } \\
\text { from } \\
\text { theoretical } \\
\text { value }\end{array}$ & $\begin{array}{l}\text { Percont error } \\
\text { from Real } \\
\text { Al(OH)3 } \\
\text { sample value }\end{array}$ \\
\hline 5 & B000307 & 13.3 & 2.80 & 8.18 & 162 & 42.2 & 50.7 \\
\hline 6 & B000296 & 50.7 & 4.53 & 13.1 & 387 & 38.0 & 17.8 \\
\hline 7 & B000298 & 170 & 15.1 & 43.7 & 390 & 38.8 & 18.5 \\
\hline 8 & $\mathrm{~B} 000298$ & 245 & 26.5 & 76.6 & 320 & 14.0 & 2.73 \\
\hline 12 & $\mathrm{~B} 000357$ & \multicolumn{6}{|c|}{ No Al(OH)3 Peak Recorded } \\
\hline 13 & $\mathrm{~B} 000347$ & \multicolumn{6}{|c|}{ No Al(OH)3 Peak Recorded } \\
\hline 14 & B000327 & 102 & 10.3 & 29.8 & 342 & 21.7 & 3.89 \\
\hline \multirow[t]{3}{*}{15} & B 000328 & 19.2 & 4.10 & 11.8 & 162 & 42.4 & 50.9 \\
\hline & & \multicolumn{6}{|c|}{ Theoretical latent hear of Dehydration (cal/g $\mathrm{H} 20$ ) } \\
\hline & & & & & 281 & & \\
\hline & & \multicolumn{6}{|c|}{ Latent heat of dehydration of real $\mathrm{A}(\mathrm{OH}) 3 \mathrm{sample}(\mathrm{cal} / \mathrm{g} \mathrm{H} 2 \mathrm{O}$ ) } \\
\hline & & & & & 329 & & \\
\hline
\end{tabular}

Because aluminum hydroxide is a white crystalline solid, it is suspected that the top layer of the tank is primarily composed of aluminum hydroxide (see Section 4.2). Furthermore, this top white layer of the waste is very dry in comparison to the rest of the tank waste. These two hypotheses may be confirmed in the thermal analysis graphs. In core 8 , only the top white layer of waste material was recovered. The DSC for core 8 has no water peak and a very large aluminum hydroxide peak. The TGA for core 8 strongly suggests that very little water exists in this top layer but a very large quantity of aluminum hydroxide exists in the top layer. Table 5-7 indicates that more than 75 percent of the mass of this core composite is aluminum hydroxide. This method offers only a crude analysis of the composition of the sample and will be substantiated in the chemical analysis section of this report. Cores 12 and 13, on the other hand, are composed exclusively of brown waste material. The DSC for both of these cores indicates a very large water peak but no aluminum hydroxide dehydration peak. The rest of the cores are in between these two extremes, depending on how much of the top layer was recovered. Generally, the whiter samples have a larger aluminum hydroxide peak and the browner samples have a higher water peak. The theory that this white layer is aluminum hydroxide is further confirmed in Chapter 6.0, where it is shown that aluminum is the major constituent of the top layer.

In Section 2.2, aluminum was presented as a key identifier for tank U-110 waste. The high quantities of aluminum hydroxide identified in the top layer of the waste confirm this hypothesis. 


\subsection{PARTICLE SIZE ANALYSIS}

Particle size analysis was performed on every segment that was delivered to the laboratory. The aliquot for particle size analysis was taken from the segment before the segment was homogenized. The particle size analysis was performed using the Brinkmann Particle Size Analyzer at the 222-S Laboratory. The output for these analyses is found in the segment data packages (Data Packages 1991).

To perform particle size analysis, a small amount of sample is placed in a dispersant. A dispersant is the liquid that is used to disperse and suspend the particles from the solid sample. Water was used as the dispersant for cores $5,6,7$, and segments 2 through 4 of core 14. A mixture of 75 percent glycerine and 25 percent ethanol by volume was used as the dispersant for cores $8,12,13,15$ and the first segrnent of core 14. This dispersant was placed in the Brinkmann Particle Size Analyzer. The Brinkmann Analyzer works by means of a thin beam of laser light that passes through the dispersant. The diameter of a solid particle in the dispersant can be determined by the amount of light that it blocks as the particle passes through the beam. The size that is measured by this method is across the short diameter of the particle. This method means that if a particle is oblong, the machine estimates the shortest length across the particle (i.e., the width of the oblong shape, not the length). The term "diameter" throughout this text will be used to describe the linear profile of any shape.

The data assembled from the Brinkmann Analyzer consists primarily of a statistical summary of the particle size as well as several particle size density and distribution graphs. Because of the amount of data produced by the Brinkmann Analyzer, all the data will not be included in the appendix. An example from core 6 segment 4 will be given in Appendix $\mathbb{E}$, Brown and Jensen 1993.

At the top of each of these data printout pages is an information strip containing information regarding each particle size analysis event. At the very top of each page is the sample name and file name. The sample name records which specific bottle number the sample came from. This number corresponds to a specific segment and core number. Also given in this sample name identifier is the particular dispersant used (water or ethanolglycerine). The file name identifier assigns a unique number to each particle analysis run. The cell type for each of these analyses was a magnetic stirrer as shown at the top of the page. The acquisition range indicates the size in microns that the analyzer is supposed to look for. Particle sizes below 0.5 microns cannot be detected by the analyzer. The required confidence for all samples is 95 percent. The analyzer will count particles until it has counted enough particles to reach this desired confidence.

The first page of the Brinkmann Analyzer data pages is the statistics summary page (see Appendix E, Brown and Jensen 1993). On this page, the mean, standard deviation, median, mode, and confidence of the particle sizes are given. These are given for a number of different particle size distributions. The two most important distributions for particle size analysis on tank waste are (number, length) and (number, volume). The first distribution (number, length) represents the distribution of the diameter of the particles based upon the 
particle diameter, commonly called the number distribution. The next distribution (number, volume) represents the distribution of the diameter of the particles based upon the volume of the particles, commonly called the volume distribution.

The average particle size in the number distribution ranges from 0.99 microns to 1.98 micron in diameter for the tank core samples. This distribution is graphed on the next two pages after the statistics page (see Appendix E, Brown and Jensen 1993, core 6 segment 4). The first graph is the probability number density graph. Note that on this graph, the diameters of the particles are grouped into size categories of 0.2 micron in range. The number density and number distribution graphs are graphed from 0 microns to 10 microns. The numbers of particles in each size range (shown as a percentage of the whole) are graphed against their respective size ranges to form a distribution curve. The next graph shows the cumulative particle size distribution. This curve is the integral of the first curve and is called the probability number distribution graph. It is also known as the: cumulative distribution curve. It can be seen from the probability number density graph that the most common occurrence (mode) for particle size is at 0.7 microns. The probability number distribution (cumulative) graph indicates that the majority ( 90 percent) of the identifiable particles fit within the narrow band of 0.4 to 1.5 microns. More than 99 percent of the particles have a diameter of less than 5 microns, which is characteristic of most of the segment samples taken. Although the above description generally fits most of the samples analyzed, all segment particle size analyses are different and the particle size analysis for each segment should be consulted for the broadest overview of the true particle sizes within the tank.

The average particle size in the volume distribution ranges from 2 microns to 12 microns in diameter for the various segments. Under the assumption that the density of the solid crystalline material within the tank is effectively constant, the volume distribution is also the best estimation of the mass particle size distribution of the tank. The Brinkmann Analyzer calculates particle volume as the cube of the diameter. This distribution is graphed on the two pages following the number distribution in Appendix E, Brown and Jensen 1993. As with the number distribution, the volume distribution is represented by a probability volume density graph and a probability volume distribution (cumulative) graph. The average particle size in the volume distribution is considerably larger than that of the number distribution. The mean of the volume distribution graph in Appendix E, Brown and Jensen 1993, is 5 microns. The majority of the identifiable particles are within the range of 0.5 to 20 microns. Again, for the broadest overview of the particle volume distribution within the tank, all of the particle size analyses (for each segment) should be consulted.

It is important to point out that even though more than 99 . percent of the particles in this sample (core 6 segment 4 ) have a diameter of less than 5 microns, about 50 percent of the volume (and hence the mass) of this sample is represented by particles with a diameter greater than 5 microns. This result can be explained by the fact that the volume of the particles has been calculated by the cube of the diameter of the particles. Hence, one particle with a diameter of 10 microns is equivalent in volume (and mass) to 1,000 particles with diameters of 1 micron. In the retrieval and subsequent treatment of the tanks, it may be desirable to design pumping or filtration systems for the tank particulate. In these events, 
the volume distribution of the particles should not be neglected. That is, particles with diameters of over 5 microns should be considered in these designs.

The technician who performed the particle size analysis recorded on some particle size data sheets that particles larger than 150 microns probably exist in tank U-110. Because the acquisition range on the analyzer was set for no more than 150 microns, any particles larger than $150 \mu \mathrm{m}$ will not appear in the data.

Another important consideration involving the analysis of particle size is the dispersant used. As mentioned before, the dispersant used for about one half of the samples was water. Because of the presence of some immiscible organics (mostly NPH from the drilling operations), the other half of the samples were analyzed using an ethanol-glycerine mixture to avoid agglomeration. The primary concern involved with using these dispersants is the dissolving of the particulate. Any water soluble (or ethylene-glycerine soluble) particles existing in the tank will dissolve or decrease in size during the analysis. This means that the particle size analysis presented in the tank U-110 data packages may not represent the true particle size distribution in the tank. If for any reason a true particle size distribution is required, the mother liquor of the tank should have been used because the tank particulate are already in equilibrium with the tank mother liquor. However, because retrieval operations will probably be performed with water, the particle size data acquired should be accurate.

There is no recognizable difference in the particle size distribution curves between the water dispersant and the ethylene-glycerine dispersant analyses. A statistical analysis of the particle size data would have to be performed to prove if there was a difference or not. A statistical analysis of particle size distribution will not be performed in this report. It may also be of some use to fit the particle size data to a particle size distribution curve, however this will not be performed in this report. 


\subsection{CHEMICAL AND RADIOLOGICAL ANALYSIS}

\subsection{CHEMICAL AND RADIOLOGICAL METHODS}

After the segment and composite samples from tank U-110 were homogenized, they were prepared for analysis. Four different downstream preparations were used for the analysis of tank U-110 core samples:

- Untreated aliquot

- Water digestion

- Acid digestion

- Potassium hydroxide (KOH) fusion.

These preparations, as well as the analytical methods associated with each preparation, will be discussed in this section. Each respective preparation brings a larger fraction of the total weight of the sample into solution. Fusion preparation brings virtually all of the sample into solution.

The first method of preparation was to analyze the untreated sample without bringing it into solution. The untreated sample was used to determine the $\mathrm{pH}$ of the waste as well as the mass percent water of the waste. The $\mathrm{pH}$ was determined using a 1:1 mixture of the untreated sample with water. The mass percent water was determined by drying the sample overnight in an oven and measuring the gravimetric difference in the mass of the sample. This procedure is similar to that of the TGA analysis except that the drying is slower and the temperature of drying is constant.

The second preparation method was water digestion. Water digestion involves dissolving as much of the sample as possible in water. Water digestion allows analysis of the soluble analytes to be performed. Water digestion serves a primary purpose in the analysis of anions by ion chromatography (IC). The primary anions that were analyzed in this manner are fluoride, chloride, nitrate, nitrite, phosphate, and sulfate. Total carbon (TC) and total organic carbon (TOC) were also analyzed from the water digestion samples.

A radiological analysis was performed on some of the water digestion samples to indicate the water soluble radionuclides. Some of the primary radionuclides detected in this analysis are plutonium, carbon 14 , strontium, technetiurn, cesium, and tritium. A total alpha and total beta count were performed on the water digestion samples as well.

Atomic absorption spectroscopy (AAS) was performed on some of the water digestion samples to determine if there was any appreciable amount of soluble arsenic, mercury, or selenium. In most cases, these analytes were below the detection limits in the water digestion samples.

The last type of analysis performed on water digestion samples was inductively coupled plasma (ICP) analysis. ICP analysis is used to detect certain elements (generally metals) found in the waste samples. Hence, when ICP is used with a water digestion solution 
sample, water soluble ions are detected. ICP analysis on water digested samples may be of particular interest when determining the water soluble species of the element is desired. In this report, ICP results on fused and dissolved samples are called fusion ICP results and ICP results on acid-dissolved samples are called acid ICP results.

The third preparation method is acid digestion. In this method of sample preparation, the sample is dissolved in hydrochloric acid. This preparation brings most of the insoluble metals into solution and is best used for the detection of trace and some major metals. The two analyses used on this preparation were the ICP analysis and the AAS analysis. Radiological and IC analysis were not used with acid digestion preparation solution.

Analyzing acid digestion solution using ICP analysis detects elemental compositions within the waste, especially trace and major metals. The fundamental purpose in determining trace metals in the tank was because of regulatory requirements. When tank U-110 was initially sampled, it was not known whether to retrieve the waste or to leave it in the tanks. Since then, the decision has been made to retrieve all waste from the tanks. Hence, the need to know the concentrations of most of the regulatory trace metals has declined. Some elements occur in the tank in a relatively large quantities and are referred to as the major metals. In some cases it is more beneficial to use fusion ICP results for some of the major metals (see below).

Again, arsenic, mercury, and selenium were analyzed on acid digestion samples. These elements were detectable in acid digestion whereas in water digestion they were not, which indicates that these elements generally occur in the tank in insoluble forms.

The final preparation used was $\mathrm{KOH}$ fusion. This preparation brought essentially everything into solution whereas the acid digestion procedure did not dissolve everything completely. Fusion analysis was originally developed to obtain estimates of the total sample content. There is, however, one disadvantage of fusion preparation. Large amounts of $\mathrm{KOH}$ are required to bring a sample into solution, which means that a large dilution is involved. Because of this high dilution, trace elements are less likely to be analyzed correctly, if they are detected at all. Elements that do occur in abundance (major metals) are likely to be detected better by fusion ICP analysis than by acid ICP analysis.

Major metals that were detected well with fusion ICP analysis for tank U-110 were aluminum, calcium, iron, magnesium, silicon, and sodium. In the case of these elements, the $\mathrm{KOH}$ fusion is the preferred method of analysis. Because a nickel crucible is used in the fusion dissolution of the sample, nickel results in the ICP analysis should be disregarded. Also, because $\mathrm{KOH}$ is the substance used to dissolve the sample, potassium readings on the ICP should also be disregarded. The two analyses that were performed on fusion-prepared samples were ICP and radiological analysis.

Fusion dissolution is the preferred method of analyzing radionuclide content with the exception of carbon-14 and tritium, which should be performed on water digestion. 
The analyses were performed on all of the composite samples but not all of these analyses were performed on segment samples. The most noteworthy example of this is for fusion ICP. Because fusion ICP analysis is not included for segment analysis, the major metals listed above are not well characterized for segment samples. Because these metals account for more than 90 percent of the cations in the tank, this problem should be corrected in future tank characterization efforts by including fusion ICP in the agenda for segment analysis.

\subsection{CHEMICAL AND RADIOLOGICAL DATA SUMMARY}

The segment data packages for tank $U-110$ are each approximately 150 pages long (except for core 14 segments which are about 350 pages long) and the composite data packages are each approximately 450 pages long. The data from these packages are summarized in Appendixes A and B, Brown and Jenser 1993. Because of the large amount of data involved, data summaries of the concentration estimates are presented in Table 6-1 for the segment data and in Table 6-2 for the composite data (Data Packages 1991). These data summary tables are condensed from the raw segment and composite data tables found in Appendixes A and B (Brown and Jensen 1993), respectively.

The segment and composite data tables were created by taking selected analytes from the raw data tables in Appendixes A and B, Brown and Jensen 1993. These selected analytes consist primarily of the abundant analytes but also consist of some regulatory elements or elements of interest. Tables 6-1 and 6-2 best summarize the contents of tank U-110. For reference to any analyte that is not contained in the dati summary tables, refer to the raw data tables in Appendixes A and B, Brown and Jensen 1993. The data presented in these tables represent the average between the sample and the duplicate. The appearance of a " 0 " in the place of the data value means that the analysis was not performed. When a " $0 \mathrm{~L}$ " is encountered, it means that the analysis was performed but the instruments could not detect the concentration of the analyte, (i.e., less than the detection limits).

The data presented in these summary tables are taken directly from the data packages. There are several inconsistencies in this data, including the significant figures of the concentrations given. For example, it is very unlikely that aluminum can be detected to $1 \mu \mathrm{g} / \mathrm{g}$, but in the core 5 composite the fusion ICP records aluminum is recorded as $12364 \mu \mathrm{g} / \mathrm{g}$.

The segment data are located in Appendix A (Tables A-1-1 to A-11-2), Brown and Jensen 1993. Data are given for the 22 segments that were analyzed from tank U-110 (Data Packages 1991). Each page contains data for two segments and two pages are required to present the data for these two segments. For example, on the first table (Table A-1-1, Brown and Jensen 1993), the data from core 5, segment 3 and core 5, segment 4 are presented. The untreated sample results are given first, followed by the fusion dissolution, water digestion, and acid digestion results. The acid digestion results for these two tanks are continued on Table A-1-2, Brown and Jensen 1993. Likewise, core 6, segment 2 and core 6, segment 3 are presented in Table A-2-1 and Table A-2-2, Brown and Jensen 1993. 
Table 6-1. Summarized Segment Data for Tank U-110. (4 sheets)

\begin{tabular}{|c|c|c|c|c|c|c|}
\hline Analyte & $\begin{array}{c}\text { Core } 5 \\
\text { Segment } 3 \\
\end{array}$ & $\begin{array}{c}\text { Core } 5 \\
\text { Segment } 4\end{array}$ & \begin{tabular}{r|} 
Core 6 \\
Segment 2
\end{tabular} & $\begin{array}{c}\text { Core } 6 \\
\text { Segment } 3\end{array}$ & \begin{tabular}{c|} 
Core 6 \\
Segmeni 4 \\
\end{tabular} & \begin{tabular}{|c|} 
Core 7 \\
Segmenl 1
\end{tabular} \\
\hline \multicolumn{7}{|c|}{ Direct - no sample preparation } \\
\hline $\mathrm{pH}$ & 12.6 & 12.8 & 11.7 & 12.4 & 12.1 & 9.69 \\
\hline \% water (weight \%) & 39.1 & 38.9 & 38.5 & 44.5 & 37.9 & 3.62 \\
\hline \multicolumn{7}{|c|}{ Radiochemistry (fusion) uCi/g } \\
\hline Total $\alpha$ & 0.742 & 0.401 & 2.63 & 0.268 & $0 \mathrm{~L}$ & 0.188 \\
\hline Total B & 1880 & 1110 & 1620 & 1580 & 85 & 20 \\
\hline GEA Cs-137 & 34.6 & 45.6 & 33.8 & 23.2 & 21.0 & 7.52 \\
\hline Uranium (ug/g) & 12800 & 2520 & 14000 & 5590 & 1350 & 35 \\
\hline \multicolumn{7}{|c|}{ IC Analysis (water) ug/g } \\
\hline Fluoride & 1420 & 21700 & $0 \mathrm{~L}$ & 3190 & 17900 & $0 \mathrm{~L}$ \\
\hline Nitrate & 73800 & 62700 & 49700 & 52200 & 26000 & 194 \\
\hline Phosphate & 10500 & 44600 & $0 \mathrm{~L}$ & 23800 & 152000 & 216 \\
\hline \multicolumn{7}{|c|}{ Carbon analysis (water) ug/g } \\
\hline Total carbon & 2020 & 4860 & 2620 & 10000 & 0 & 0 \\
\hline TOC & 542 & 980 & 0 & 0 & 710 & 673 \\
\hline \multicolumn{7}{|c|}{ ICP Analysis (acid) ug/g } \\
\hline Aluminum & 126000 & 36300 & 91600 & 89700 & 49000 & 85400 \\
\hline Bismuth & 4250 & 20300 & 5040 & 19500 & 24100 & 527 \\
\hline Calcium & 567 & 154 & 1000 & 507 & 704 & 156 \\
\hline Iron & 8230 & 8040 & 18100 & 12800 & 15900 & 1990 \\
\hline Magnesium & 952 & 125 & 4890 & 2000 & 464 & 116 \\
\hline Manganese & 5240 & 2010 & 6650 & 5630 & 213 & 253 \\
\hline Silicon & 2800 & 834 & 2950 & 4320 & 2480 & 625 \\
\hline Sodium & 78200 & 65500 & 77700 & 87600 & 178000 & 2906 \\
\hline
\end{tabular}


WHC-SD-WM-ER-551 Rev. 0

Table 6-1. Summarized Segment Data for Tank U-110. (4 sheets)

\begin{tabular}{|c|c|c|c|c|c|c|}
\hline Analyte & $\begin{array}{c}\text { Core } 7 \\
\text { Segment } 2\end{array}$ & $\begin{array}{c}\text { Core } 7 \\
\text { Segment } 3\end{array}$ & $\begin{array}{c}\text { Core } 7 \\
\text { Segment } 4\end{array}$ & $\begin{array}{c}\text { Core } 8 \\
\text { Segment } 1\end{array}$ & $\begin{array}{c}\text { Core } 12 \\
\text { Segment } 2\end{array}$ & \begin{tabular}{|c|} 
Core 12 \\
Segment 3
\end{tabular} \\
\hline \multicolumn{7}{|c|}{ Direct - no sample preparation } \\
\hline $\mathrm{pH}$ & 12.7 & 12.7 & 11.15 & 10.5 & 12.9 & 12.13 \\
\hline$\%$ water (weight $\%$ ) & 35.9 & 47.4 & 37.4 & 8.39 & 40.9 & 39.0 \\
\hline \multicolumn{7}{|c|}{ Radiochemistry (fusion) uCi/g } \\
\hline Total $\alpha$ & 1.69 & 2.84 & 0.131 & 0.009 & 0.931 & 0.437 \\
\hline Total B & 827 & 1570 & 152 & 3.00 & 1345 & 910 \\
\hline GEA Cs-137 & 17.7 & 22.9 & 28.6 & 0.390 & 32.5 & 58.9 \\
\hline Uranium (ug/g) & 12900 & $0 \mathrm{~L}$ & 1680 & 1050 & 1260 & 1890 \\
\hline \multicolumn{7}{|c|}{ IC Analysis (water) ug/g } \\
\hline Fluoride & $0 \mathrm{~L}$ & 3020 & 15600 & 30 & 1565 & 15600 \\
\hline Nitrate & 27900 & 39800 & 27700 & 279 & 31200 & 69800 \\
\hline Phosphate & $0 \mathrm{~L}$ & 18400 & 123000 & 163 & $0 \mathrm{~L}$ & 50500 \\
\hline \multicolumn{7}{|c|}{ Carbon analysis (water) ug/g } \\
\hline Total carbon & 0 & 2260 & 7370 & 1550 & 0 & 0 \\
\hline TOC & 1510 & 0 & 0 & 853 & 787 & 724 \\
\hline \multicolumn{7}{|c|}{ ICP Analysis (acid) ug/g } \\
\hline Aluminum & 130000 & 84000 & 56200 & 104000 & 136000 & 45600 \\
\hline Bismuth & 2630 & 12400 & 32600 & $0 \mathrm{~L}$ & $\mathbf{7 4 7 0}$ & 39200 \\
\hline Calcium & 319 & 665 & 514 & 116 & 949 & 465 \\
\hline Iron & 5950 & 12700 & 20800 & 150 & 27800 & 22400 \\
\hline Magnesium & 2200 & 7450 & 346 & 25 & 3170 & 429 \\
\hline Manganese & 3910 & 5840 & 380 & 44 & 8860 & 950 \\
\hline Silicon & 4430 & 4290 & 2260 & 0 & 3900 & 2510 \\
\hline Sodium & 49100 & 85800 & 188000 & 1110 & 80300 & 113000 \\
\hline
\end{tabular}


Table 6-1. Summarized Segment Data for Tank U-110. (4 sheets)

\begin{tabular}{|c|c|c|c|c|c|c|}
\hline Analyte & $\begin{array}{c}\text { Core } 12 \\
\text { Segment } 4\end{array}$ & $\begin{array}{c}\text { Core } 13 \\
\text { Segment } 3\end{array}$ & $\begin{array}{c}\text { Core } 13 \\
\text { Segment } 4\end{array}$ & $\begin{array}{c}\text { Core } 14 \\
\text { Segment } 1\end{array}$ & $\begin{array}{c}\text { Core } 14 \\
\text { Segment } 2\end{array}$ & \begin{tabular}{|c|} 
Core 14 \\
Segment 3
\end{tabular} \\
\hline \multicolumn{7}{|c|}{ Direct - no sample preparation } \\
\hline$\overline{\mathrm{pH}}$ & 12.5 & 12.3 & 12.7 & 7.87 & 12.3 & 12.1 \\
\hline$\%$ water (weight \%) & 44.2 & 43.1 & 45.7 & 5.17 & 28.0 & 42.6 \\
\hline \multicolumn{7}{|c|}{ Radiochemistry (fusion) uCi/g } \\
\hline Total $\alpha$ & 0.597 & 0 & $0 \mathrm{~L}$ & 0.008 & 0.156 & 1.40 \\
\hline Total B & 2010 & 1840 & 906 & 2.00 & 47.0 & 1280 \\
\hline GEA Cs-137 & 23.0 & 54.3 & 25.7 & $0 \mathrm{~L}$ & 19.2 & 23.3 \\
\hline Uranium (ug/g) & 6970 & 6060 & 3730 & 44.0 & 8980 & 2630 \\
\hline \multicolumn{7}{|c|}{ IC Analysis (water) ug/g } \\
\hline Fluoride & 1660 & 1720 & 2960 & $0 \mathrm{~L}$ & 524 & 3230 \\
\hline Nitrate & 54000 & 54100 & 83500 & $0 \mathrm{~L}$ & 36400 & 61300 \\
\hline Phosphate & $0 \mathrm{~L}$ & $0 \mathrm{~L}$ & $0 \mathrm{~L}$ & $0 \mathrm{~L}$ & 1870 & 13800 \\
\hline \multicolumn{7}{|c|}{ Carbon analysis (water) ug/g } \\
\hline Total Carbon & 0 & 0 & $\mathbf{0}$ & 1500 & 2790 & 9460 \\
\hline TOC & 807 & 559 & 841 & 428 & 626 & 446 \\
\hline \multicolumn{7}{|c|}{ ICP Analysis (acid) ug/g } \\
\hline Aluminum & 42500 & 111000 & 47200 & 72300 & 101000 & 20000 \\
\hline Bismuth & 5870 & 13800 & 17000 & $0 \mathrm{~L}$ & 2440 & 2730 \\
\hline Calcium & 504 & 1490 & 377 & 109 & 258 & 122 \\
\hline Iron & 7620 & 13500 & 27300 & 441 & 4670 & 2250 \\
\hline Magnesium & 664 & 776 & 138 & 101 & 629 & 41 \\
\hline Manganese & 6980 & 9920 & 3730 & $0 \mathrm{~L}$ & 3430 & 1370 \\
\hline Silicon & 2940 & 4480 & 681 & $0 \mathrm{~L}$ & 2200 & 1550 \\
\hline Sodium & 49900 & 78300 & 89500 & $0 \mathrm{~L}$ & 45000 & 20700 \\
\hline
\end{tabular}


WHC-SD-WM-ER-551 Rev. 0

Table 6-1. Summarized Segment Data for Tank U-110. (4 sheets)

\begin{tabular}{|c|c|c|c|c|c|c|}
\hline Analyte & $\begin{array}{c}\text { Core } 14 \\
\text { Segment } 4\end{array}$ & $\begin{array}{c}\text { Core } 15 \\
\text { Segment } 2\end{array}$ & \begin{tabular}{|c|} 
Core 15 \\
Segment 3 \\
\end{tabular} & $\begin{array}{c}\text { Core 15 } \\
\text { Segment } 4\end{array}$ & & \\
\hline \multicolumn{5}{|c|}{ Direet - no sample preparation } & & \\
\hline$\overline{\mathrm{pH}}$ & $\overline{12.5}$ & 11.9 & 13.2 & 12.2 & & \\
\hline$\%$ water (weight \%) & 37.3 & 41.5 & 42.9 & 41.1 & & \\
\hline \multicolumn{5}{|c|}{ Radiochemistry (fusion) uCi/g } & & \\
\hline Total $\alpha$ & 0.296 & 2.28 & 2.15 & 0.119 & & \\
\hline Total B & 237 & 1470 & 1480 & 204 & & \\
\hline GEA Cs-137 & 23.5 & 24.3 & 30.1 & 43.3 & & \\
\hline Uranium (ug/g) & 1440 & 13000 & 5580 & 1550 & & \\
\hline \multicolumn{5}{|c|}{ IC Analysis (water) ug/g } & & \\
\hline Fluoride & 195000 & 1460 & 3540 & 24100 & & \\
\hline Nitrate & 30300 & 32200 & 45800 & 33600 & & \\
\hline Phosphate & 137000 & $0 \mathrm{~L}$ & 19200 & 99600 & & \\
\hline \multicolumn{5}{|c|}{ Carbon analysis (water) ug/g } & & \\
\hline Total Carbon & 15800 & 0 & 2090 & 9000 & & \\
\hline TOC & 1100 & 6590 & 0 & 0 & & \\
\hline \multicolumn{5}{|c|}{ ICP Analysis (acid) ug/g } & & \\
\hline Aluminum & 52600 & 84800 & 89600 & 60700 & & \\
\hline Bismuth & 24800 & 3860 & 22100 & 47300 & & \\
\hline Calcium & 303 & 500 & 626 & 483 & & \\
\hline Iron & 12200 & 7290 & 15100 & 24100 & & \\
\hline Magnesium & 213 & 1040 & 237 & 716 & & \\
\hline Manganese & 899 & 5150 & 5780 & 534 & & \\
\hline Silicon & 2900 & 2520 & 3660 & 4700 & & \\
\hline Sodium & 151000 & 64500 & 81700 & 181000 & & \\
\hline
\end{tabular}

GEA = Gamma energy analysis

IC = Ion Chromatography

ICP = Inductively Coupled Plasma

TOC $=$ Total Organic Carbon 
Table 6-2. Summarized Composite Data for Tank U-110. (2 sheets)

\begin{tabular}{|c|c|c|c|c|c|c|c|c|}
\hline Anilyte & Core 5 & Corn 6 & Coro 7 & Core 8 & $\operatorname{cor} 11$ & Cort 13 & Core 14 & Core 15 \\
\hline \multicolumn{9}{|c|}{ Direct - No Sample Preparation } \\
\hline pH & 12.9 & 12.9 & 12.7 & 10.5 & 12.7 & 12.7 & 12.5 & 12.5 \\
\hline \% Water & 33.5 & 37.0 & 25.8 & 8.39 & 39.5 & 39.8 & 25.8 & 42.1 \\
\hline \multicolumn{9}{|c|}{ IC Anulynin (Water) ud/s } \\
\hline Fluoride & 9290 & 5720 & 5900 & 30 & 9030 & 4270 & 8950 & 6190 \\
\hline Nitrate & 48200 & 45600 & 28200 & 279 & 50100 & 60100 & 35300 & 48250 \\
\hline Phosphate & 19600 & 35100 & 36200 & 163 & 43500 & 15100 & 51600 & 25900 \\
\hline Cartonate & 2730 & o & 5180 & 0 & 7270 & 8310 & 1220 & 0 \\
\hline Nitrite & 10400 & 10100 & 4850 & 12600 & $0 \mathrm{~L}$ & 12000 & 8390 & 9140 \\
\hline \multicolumn{9}{|c|}{ Carbon Analyais (Water) ug/c } \\
\hline Total Carbon & 0 & 787 & 0 & 1550 & 0 & 0 & 0 & 0 \\
\hline TOC & $\mathbf{0}$ & $0 \mathrm{~L}$ & 983 & 853 & 1040 & 189 & 1720 & 1010 \\
\hline \multicolumn{9}{|c|}{ Rediochemistry (Fusion) uCi/g } \\
\hline GEA Cs-137 & 38.3 & 23.0 & 17.7 & 0.390 & 53.5 & 29.9 & 17.6 & 17.3 \\
\hline Unanium (ug/g) & 5300 & 5590 & 4080 & 1050 & 6860 & 5620 & 3420 & 3800 \\
\hline Plutonium & 0.345 & 0.264 & 0.195 & 0.005 & 0.356 & 0.268 & 0.149 & 0.177 \\
\hline Americium-241 & 0.070 & 0.119 & 0.065 & 0.017 & 0.000 & 0.132 & 0.063 & 0.074 \\
\hline Strontium-90 & 364 & 321 & 269 & 1.00 & 470 & 524 & 252 & 0 \\
\hline \multicolumn{9}{|c|}{ Radiochenvistry (Water) uCi/z } \\
\hline GEA C -137 & 13.8 & 5.74 & 2.13 & 0.260 & 8.64 & 9.25 & 5.88 & 5.28 \\
\hline Plutonium & 0.000860 & $0 \mathrm{~L}$ & 0.00154 & $0 \mathrm{~L}$ & $0 \mathrm{~L}$ & $0 \mathrm{~L}$ & $0 \mathrm{~L}$ & $0 \mathrm{~L}$ \\
\hline Strontium-90 & 0.067 & 0.064 & 0.346 & 0.065 & 0.128 & 0.046 & 0.117 & 0.067 \\
\hline Technetium-99 & 0.00485 & 0.0224 & 0.00305 & $0 \mathrm{~L}$ & 0.00711 & 0.00593 & 0.00377 & 0.00301 \\
\hline \multicolumn{9}{|c|}{ ICP Analynis (Fusion) ug/s } \\
\hline Aluminum & 112000 & 96200 & 169000 & 309000 & 143000 & 148000 & 168000 & 215000 \\
\hline Bismuth & 39700 & 13900 & 19000 & $0 \mathrm{~L}$ & 31100 & 0 & 8940 & 11300 \\
\hline Calcium & 3520 & 1440 & 3600 & 3280 & 6170 & 4380 & 2120 & 1190 \\
\hline Iron & 17300 & 12700 & 12300 & 493 & 15300 & 16600 & 7880 & 4640 \\
\hline Magnesium & 7490 & 2110 & 1610 & 572 & 2490 & 1820 & 1110 & 1150 \\
\hline Manganese & 4930 & 3430 & 2240 & 60 & 4360 & 4600 & 2240 & 2420 \\
\hline Silicon & 20000 & 0 & 10900 & 0 & o & 35800 & o & 0 \\
\hline Sodium & 143000 & 130000 & 106000 & 5050 & 114000 & 79400 & 111000 & 96500 \\
\hline
\end{tabular}


Table 6-2. Summarized Composite Data for Tank U-110. (2 sheets)

\begin{tabular}{|c|c|c|c|c|c|c|c|c|}
\hline Anelyte & $\cos 5$ & Corn 6 & Core? & Core 8 & Con 12 & Cort 13 & Cone 14 & Gore 15 \\
\hline \multicolumn{9}{|c|}{ ICP Analyais (Water) ug/g } \\
\hline Aluminum & 4610 & 3260 & 2390 & 0 & 3390 & 2830 & 2940 & 5140 \\
\hline Binmuth & 0 & 0 & 0 & 0 & 0 & $0 \mathrm{~L}$ & $O L$ & 0 \\
\hline Calcium & 53 & 192 & 162 & 0 & 241 & 22 & 56 & 164 \\
\hline Iron & 31 & 75 & 41 & 0 & 51 & 17 & $0 \mathrm{~L}$ & 33 \\
\hline Mngnesium & 196 & 1370 & 498 & 0 & 256 & 83 & 136 & 129 \\
\hline Manganese & $\mathbf{O L}$ & $0 \mathrm{~L}$ & $0 \mathrm{~L}$ & 0 & 6 & $0 \mathrm{~L}$ & $0 \mathrm{~L}$ & $0 \mathrm{~L}$ \\
\hline Silicon & 0 & 0 & 0 & 0 & o & 1090 & 1640 & 0 \\
\hline Sodium & 114000 & 90600 & 52900 & 0 & 86700 & 62700 & 78600 & 78900 \\
\hline \multicolumn{9}{|c|}{ ICP Analysias (Acid) ug/e } \\
\hline Aluminum & 106000 & 101000 & 140000 & 104000 & 56600 & 56800 & 98700 & 77300 \\
\hline Bismuth & 45400 & 20100 & 10500 & $0 \mathbf{L}$ & 0 & 14900 & 8320 & 13200 \\
\hline Calcium & 559 & 583 & 337 & 116 & 602 & 534 & 294 & 550 \\
\hline Iron & 17500 & 12900 & 8820 & 150 & 16000 & 15100 & 6450 & 11100 \\
\hline Magnesium & 655 & 1680 & 333 & 25 & 489 & 224 & 289 & 855 \\
\hline Manganese & 5350 & 3830 & 2270 & 44 & 3910 & 5470 & 2450 & 5300 \\
\hline Silicon & o & 0 & 0 & 0 & 0 & 3990 & 0 & 3560 \\
\hline Sodium & 152000 & 108000 & 72500 & 1110 & 81100 & 73700 & 82500 & $\tilde{8} \overline{\mathbf{Z}} \overline{\mathbf{T}} \mathbf{\overline { N }}$ \\
\hline
\end{tabular}

GEA = Gamma energy ansly sis

IC $=$ Ion Chromatography

ICP = Inductively Couplod Plasma 
The composite data are located in Appendix B, Brown and Jensen 1993. The data are found in Tables B-1-1 to B-4-6. The data are given for the eight core composites that were analyzed from tank U-110 (Data Packages 1991). Fach page contains data for two composites and six pages are required to present the data for these two composites. For example, on the first table (Table B-1-1, Brown and Jensen 1993), the data from composite 5 and composite 6 are presented. The data from these two composites are given from Table B-1-1 through Table B-1-6, Brown and Jensen 1993. The order of presentation is the same as with the segment data. That is, the undigested sample data is presented first, followed by the fusion, water, and finally the acid data. However, more analyses were performed on core composites. Likewise, composite 7 and composite 8 are presented from Table B-2-1 through Table B-2-6, Brown and Jensen 1993.

The layout of the data is the same for both appendixes (Brown and Jensen 1993). The sample value is presented first, followed by the duplicate value. These represent analyses that were performed on two aliquots that were taken from the same sample. These values should be very similar to each other. Next to some of these sample and duplicate values is the letter "L." This "L" means "less than" and signifies that the number shown is the detection limit value. This means that the actual concentration of that analyte is less that the detection limit. The third number given is the average of the two. Actually, the third number shown is only the average of the sample and duplicate value if both the sample and duplicate are not "less than" values. If the sample value is a "less than" value, the number shown in the average column is the duplicate value and vice versa. If both of the values are "less than" values, a " $0 \mathrm{~L}$ " is shown. This signifies that in both cases, the analyte in question was not detected. If neither the sample or duplicate was analyzed, a " 0 " is shown in the average column signifying that value is missing. It is up to the data user to decide if a "less than". should be treated as a missing value, or as the number 0 , or as the actual detection limit. For the statistical analysis given later in this report, the "less than" values were treated as being missing values. For the mass and charge balances performed later in this report, the number 0 was used in place of the "less than values."

Sample data that are not presented in Appendix A. or B, Brown and Jensen 1993, will have to be obtained from the actual data packages (see Section 10.1 Data Packages, for references). This includes information such as spike recoveries, reagent blanks, and other similar data that will not be considered in this report.

\subsection{DATA VALIDATION}

Data validation procedures-for-both-chemicat-and radiotogical-data were in place during the analysis of tank U-110. The procedures for the validation of chemical data, also known as Resource Conservation and Recovery Act of 1976 (RCRA) data, are described in detail in WHC-CM-5-3, Sample Management and Administration, Section 2.0 (WHC 1991). The procedures for validating radiological data are outlined in Section 2.4 of the same manual. Validation of the radiological data for tank U-110 was not performed because of time constraints. However, validation of the chemical (RCRA) data for tank U-110 was 
performed. A brief summary of the procedure used for this validation, as well as the results of the validation, is included in this section.

The requirements for validating (RCRA) data are as follows:

- Requested versus reported analyses

- Analysis holding times

- Matrix spike/matrix spike duplicate analysis

- Surrogate recoveries

- Duplicate analysis

- Analytical blank analysis

- Initial and continuing instrument calibration

- Internal standards

- Laboratory control samples

- Interference check sample.

When determining the quality of the chemical data for tank $U-110$, it is most useful to consider the blank analysis, the spike analysis, the duplicate analysis, and the control samples. An assessment of these quality control checks was made on all of the core composite results.

Assessment of analytical blanks shows the potential contamination problems that could potentially yield false positive results. The purpose of the matrix spike analysis is to estimate the effect of sample matrix on the results. Duplicate analysis compares the difference between the sample and the duplicate sample and provides an indication of laboratory precision. Finally, the laboratory control sample offers a way to monitor the overall performance of an analytical method in all steps of the analysis.

The analytical blank analysis indicated that tank $U-110$ data was free of contamination errors. However, the remaining tests did not yield the good results that the blank test did. Only 9 percent of the sample data points passed the matrix spike analysis, the blank analysis, and the laboratory control sample check. Another 14 percent of the sample data points did not have one or more of the quality control analyses performed on them. Hence, it is indeterminable if these are quality data points or not. The remaining 77 percent of the data points failed one, two, or three of these tests. These data points are referred to as estimated data points. Consequently, there is much uncertainty about the quality of tank U-110 data. Most of the spike and laboratory control problems were located in the ICP results. However, the duplication problems were poor throughout all of the analyses. Some of the duplication problems-may-have-resulted-from poor-homogenization of the samples. The ability of the laboratory to homogenize the samples will be discussed in Section 7.0.

The data quality analyses were assessed for each of the major analytes in the tank for the core composition data. The major analytes are those analytes that exist in the tank with a bulk average concentration of over 1 percent. A list of major analytes is provided in the executive summary. Of this list of major analytes, water is the only analysis that did not fail 
any of the data quality tests. Aluminum had a matrix spike error in every composite sample except for core 15 , which did not undergo the spike test. However, aluminum was the only major analyte besides water that experienced no duplication problems. The major cations sodium, bismuth, and iron, as well as the analyte silicon, all experienced problems in every sample with one or more of the aforementioned data quality checks. The major anions, nitrate and phosphorus, were free of spiking problems but did experience some duplication problems.

The quality of the data for tank U-110 is in question. Essentially, none of the analytes of any significance in the tank have passed quality control requirements. Regardless of the lack of confidence in the quality of the tank U-110 data from the 1989 samples, this information is the only current source of characterization information. The approach that will be used in the data analysis in the remainder of Section 6.0 of this report, as well as in the statistical analysis in Section 7.0 of this report, will be to assume that there are no faults with the data and heavily qualify any results or conclusions arrived at from the data without an independent corroborating source (i.e., tank surveillance or historical data). This assumption must be made to complete the characterization of the waste in the tank.

\subsection{INTERPRETATION OF SEGMENT DATA}

Interpretation of the tank $\mathrm{U}-110$ segment data depends on the needs of the data user and only a basic and brief data interpretation will be presented in this report. In this section, trend analysis of the segment data will be considered. Material and charge balances on segment data will not be performed, primarily because of the lack of fusion ICP data on the segment analyses.

One important use of segment data that cannot be performed with composite data is to observe the concentration of a particular analyte as a function of the waste depth. It is observed in tank U-110 that many of the major analytes have a varying concentration over the depth of the tank and that many of these trends are similar throughout the cores of the tank. These concentration-depth profiles will be referred to in this section as trends.

The analytes that will be presented in these trending profiles are water, ${ }^{137} \mathrm{Cs}$, uranium, fluoride, nitrate, phosphate, TC, aluminum, bismuth, iron, and sodium. Many of these analytes will be discussed in this section as well. The trending charts for these analytes are given in Tables 6-3 through 6-13. These trending charts show the concentration of the particular analyte for each core containing three or more recovered segments taken from the tank. Finally, -an-average-of the-eight -cores is -shown at -the end-of the table. The first segment depicts the waste in only approximately the first $10 \mathrm{~cm}(4 \mathrm{in}$.) from the top of the waste surface, the white layer mentioned in Section 4.2. Each segment below segment 1 represents the next $48 \mathrm{~cm}$ (19 in.) of waste in the tank ending with segment 4 , which consists of the bottom $48 \mathrm{~cm}$ (19 in.) of waste in the tank. 
Table 6-3. Trending Chart for Water (Weight \% Water).

\begin{tabular}{|c|c|c|c|c|c|c|c|c|c|}
\hline \multirow{2}{*}{ Segment } & \multicolumn{9}{|c|}{ Core } \\
\hline & 5 & 6 & 7 & 8 & 12 & 13 & 14 & 15 & Average \\
\hline 1 & & & 3.62 & 8.39 & & & 5.17 & & 5.7 \\
\hline 2 & & 38.5 & 35.9 & & 40.9 & & 28.0 & 41.5 & 36.9 \\
\hline 3 & 39.1 & 44.5 & 47.4 & & 39.0 & 43.1 & 42.6 & 42.9 & 42.7 \\
\hline 4 & 38.9 & 37.9 & 37.4 & & 44.2 & 45.7 & 37.3 & 41.1 & 40.4 \\
\hline
\end{tabular}

Table 6-4. Trending Chart for Cesium-137 (from Fusion Radiochemistry - uCi/g).

\begin{tabular}{|c|c|c|c|c|c|c|c|c|c|}
\hline \multirow{2}{*}{ Segment } & \multicolumn{9}{|c|}{ Core } \\
\hline & 5 & 6 & 7 & 8 & 12 & 13 & 14 & 15 & Average \\
\hline 1 & & & 7.52 & 0.390 & & & & & 3.90 \\
\hline 2 & & 33.8 & 17.7 & & 32.5 & & 19.2 & 24.3 & 25.5 \\
\hline 3 & 34.6 & 23.2 & 22.9 & & 58.9 & 54.3 & 23.3 & 30.1 & 35.3 \\
\hline 4 & 45.6 & 21.0 & 28.6 & & 23.0 & 25.7 & 23.5 & 43.3 & 30.1 \\
\hline
\end{tabular}

Table 6-5. Trending Chart for Uranium (from Fusion Radiochemistry - ug/g).

\begin{tabular}{|c|r|r|r|r|r|r|r|r|r|}
\hline Segment & \multicolumn{1}{|c|}{5} & \multicolumn{1}{|c|}{5} & 7 & 8 & 12 & 13 & 14 & 15 & Average \\
\hline 1 & & & 35 & 1050 & & & 44 & & 377 \\
2 & & 14000 & 12900 & & 12600 & & 8980 & 13000 & 12000 \\
3 & 12800 & 5590 & & & 1890 & 6060 & 2630 & 5580 & 5760 \\
4 & 2520 & 1350 & 1680 & & 6970 & 3730 & 1440 & 1550 & 2750 \\
\hline
\end{tabular}

Table 6-6. Trending Chart for Fluoride (from Water IC - ug/g).

\begin{tabular}{|c|c|c|c|c|c|c|c|c|c|}
\hline \multirow{2}{*}{ Segment } & \multicolumn{9}{|c|}{ Core } \\
\hline & 5 & 6 & 7 & 8 & 12 & 13 & 14 & 15 & Average \\
\hline 1 & & & & 30 & & & & & 30 \\
\hline 2 & & & & & 1560 & & 524 & 1460 & 1180 \\
\hline 3 & 1420 & 3190 & 3020 & & 15600 & 1720 & 3230 & 3540 & 4530 \\
\hline 4 & 21700 & 17900 & 15600 & & 1660 & 2960 & 19500 & 24100 & 14790 \\
\hline
\end{tabular}

IC = Ion Chromatography 
Table 6-7. Trending Chart for Nitrate (from Water IC - ug/g).

\begin{tabular}{|c|c|c|c|c|c|c|c|c|c|}
\hline \multirow{2}{*}{ Segment } & \multicolumn{9}{|c|}{ Core } \\
\hline & 5 & 6 & 7 & 8 & 12 & 13 & 14 & 15 & Average \\
\hline 1 & & & 194 & 279 & & & & & 236 \\
\hline 2 & & 49700 & 27900 & & 31200 & & 36400 & 32200 & 35000 \\
\hline 3 & 73800 & 52200 & 39800 & & 69800 & 54100 & 61300 & 45800 & 56700 \\
\hline 4 & 62700 & 26000 & 27700 & & 54000 & 83500 & 30300 & 33600 & 45400 \\
\hline
\end{tabular}

IC = Ion Chromatography

Table 6-8. Trending Chart for Phosphate (from Water IC - ug/g).

\begin{tabular}{|c|c|c|c|c|c|c|c|c|c|}
\hline \multirow{2}{*}{ Segment } & \multicolumn{9}{|c|}{ Core } \\
\hline & 5 & 6 & 7 & $\begin{array}{r}8 \\
\times \quad 8\end{array}$ & 12 & 13 & 14 & 15 & Average \\
\hline 1 & & & 216 & 163 & & & & & 189 \\
\hline 2 & & & & & & & 1870 & & 1870 \\
\hline 3 & 10500 & 23800 & 18400 & & 50500 & & 13800 & 19200 & 22700 \\
\hline 4 & 44600 & 152000 & 123000 & & & & 137000 & 99600 & 111000 \\
\hline
\end{tabular}

IC = Ion Chromatography

Table 6-9. Trending Chart for Total Carbon (from Water Digestion - ug/g).

\begin{tabular}{|c|c|c|c|c|c|c|c|c|c|}
\hline \multirow{2}{*}{ Segment } & \multicolumn{9}{|c|}{ Core } \\
\hline & 5 & 6 & 7 & 8 & 12 & 13 & 14 & 15 & Average \\
\hline 1 & & & & 1550 & & & 1500 & & 1520 \\
\hline 2 & & 2620 & & & & & 2790 & & 2710 \\
\hline 3 & 2020 & 10000 & 2260 & & & & 9460 & 2090 & 5170 \\
\hline 4 & 4860 & & 7370 & & & & 15800 & 9000 & 9260 \\
\hline
\end{tabular}

Table 6-10. Trending Chart for Aluminum (from Acid ICP - ug/g).

\begin{tabular}{|c|c|c|c|c|c|c|c|c|c|}
\hline \multirow{2}{*}{ Segment } & \multicolumn{9}{|c|}{ Core } \\
\hline & 5 & 6 & 7 & 8 & 12 & 13 & 14 & 15 & Average \\
\hline 1 & & & 85400 & 104000 & & & 72300 & & 87000 \\
\hline 2 & & -91600 & 130000 & & -136000 & - & -101000 & 84800 & 109000 \\
\hline 3 & 126000 & 89700 & 84000 & & 45600 & 111000 & 20000 & 89600 & 80900 \\
\hline 4 & 36300 & 49000 & 56200 & & 42500 & 47200 & 52700 & 60700 & 49200 \\
\hline
\end{tabular}

ICP = Inductively Coupled Plasma 
Table 6-11. Trending Chart for Bismuth (from Acid ICP - ug/g).

\begin{tabular}{|c|c|c|c|c|c|c|c|c|c|}
\hline \multirow{2}{*}{ Segment } & \multicolumn{9}{|c|}{ Core } \\
\hline & 5 & 6 & 7 & 8 & 12 & 13 & 14 & 15 & Average \\
\hline 1 & & & 527 & & & & & & 527 \\
\hline 2 & & 5040 & 2630 & & 7470 & & 2440 & 3860 & 4290 \\
\hline 3 & 4250 & 19500 & 12400 & & 39200 & 13800 & 2730 & 22100 & 16300 \\
\hline 4 & 20300 & 24100 & 32600 & & 5870 & 17000 & 24800 & 47300 & 24600 \\
\hline
\end{tabular}

ICP = Inductively Coupled Plasma

Table 6-12. Trending Chart for Iron (from Acid ICP - ug/g).

\begin{tabular}{|c|c|c|c|c|c|c|c|c|c|}
\hline \multirow{2}{*}{ Segment } & \multicolumn{9}{|c|}{ Core } \\
\hline & 5 & 6 & 7 & 8 & 12 & 13 & 14 & 15 & Average \\
\hline 1 & & & 1990 & 150 & & & 441 & & 861 \\
\hline 2 & & 18100 & 5950 & & 27800 & & 4670 & 7290 & 12700 \\
\hline 3 & 8230 & 12900 & 12700 & & 22400 & 13500 & 2250 & 15100 & 12400 \\
\hline 4 & 8040 & 15900 & 20800 & & 7620 & 27300 & 12200 & 24100 & 16600 \\
\hline
\end{tabular}

ICP = Inductively Coupled Plasma

Table 6-13. Trending Chart for Sodium (from Acid ICP - ug/g).

\begin{tabular}{|c|c|c|c|c|c|c|c|c|c|}
\hline \multirow{2}{*}{ Segment } & \multicolumn{9}{|c|}{ Core } \\
\hline & 5 & 6 & 7 & 8 & 12 & 13 & 14 & 15 & Average \\
\hline 1 & & & 2910 & 1110 & & & & & 2010 \\
\hline 2 & & 77700 & 49100 & & 80300 & & 45000 & 64500 & 63300 \\
\hline 3 & 78200 & 87600 & 85800 & & 113000 & 78300 & 20700 & 81700 & 77900 \\
\hline 4 & 65500 & 178000 & 188000 & & 49900 & 89500 & 151000 & 181000 & 129000 \\
\hline
\end{tabular}

ICP = Inductively Coupled Plasma

The first analyte worth mentioning is water. Table 6-3.shows the trending data for water expressed in weight percent water. This information is also depicted in Figure 6-1. As the table and figure show, the top white layer of the tank is very dry with an average of about 6 weight percent water. This measure supports the conclusion from Section 5.0 that the top white layer of the tank is composed of very dry aluminum hydroxide. The moisture level rises in the second segment to about 40 percent water in the middle and bottom of the tank. This gradient in the concentration of water in the tank is best explained by 
considering that the tank has been drying since it was salt-well pumped in 1975. Diffusion of water to the surface of the tank (where evaporation occurs) would be greatest towards the top of the waste, which explains the dryness of the top segments as compared to those at the bottom.

Uranium (see Table 6-5 and Figure 6-2) also has an interesting trending plot. The first segment contains practically no uranium. Directly below the first segment, the concentration of the uranium rises to a peak of approximately $12,000 \mathrm{ug} / \mathrm{g}$ and then slowly decreases to about $2,000 \mathrm{ug} / \mathrm{g}$ at the bottom of the tank. This indicates that uranium has a tendency to accumulate towards the top of the waste. One reason for this may be that the later waste types, $\mathrm{R}$ and CWR, had a higher uranium content than the earlier bismuth phosphate prociess IC waste. Hence, the uranium constituents would have settled higher in the tank.

The three major anions in the tank, fluoride, nitrate, and phosphate, generally follow the same trend. This can be seen in Tables 6-6 through 6-8. The concentration is negligible at the top segment but large at the bottom. Of particular interest is phosphate, the trending graph of which is shown in Figure 6-3. The top segment has almost no phosphate but the concentration from the top to the bottom of the tank rises almost by an order of magnitude for each segment. Hence, more than 80 percent of the phosphate lies in the bottom $48 \mathrm{~cm}$ (19 in.) of the tank. This occurrence is explained by the fact that the first waste type to enter tank U-110 was 1C waste from the bismuth phosphate process, which contained high concentrations of both bismuth and phosphate. Hence, waste from this process would have been the first to settle to the bottom of the tank. Bismuth phosphate is insoluble in alkaline conditions, which would also explain why its constituents have settled at the bottom of the tank. It should also be observed from Table 6-11 that bismuth has a similar trending curve. That is, its concentration is low at the top of the waste and rises dramatically towards the bottom of the waste.

Because of the existence of the solid aluminum hydroxide layer at the top of the waste, the aluminum concentration should be expected to be high in the first segment of the tank. It is seen from Table 6-10 and Figure 6-4 that while the aluminum concentration is high in the first segment, it actually peaks in the second segment and is very high throughout the tank. This result indicates that aluminum occurs in another form than aluminum hydroxide. It will be shown in the next section that aluminum, as well as most of the other metals in the tank, probably occurs in both an oxide and a hydroxide form. 
WHC-SD-WM-ER-551 Rev. 0

Figure 6-1. Water Trend Chart.

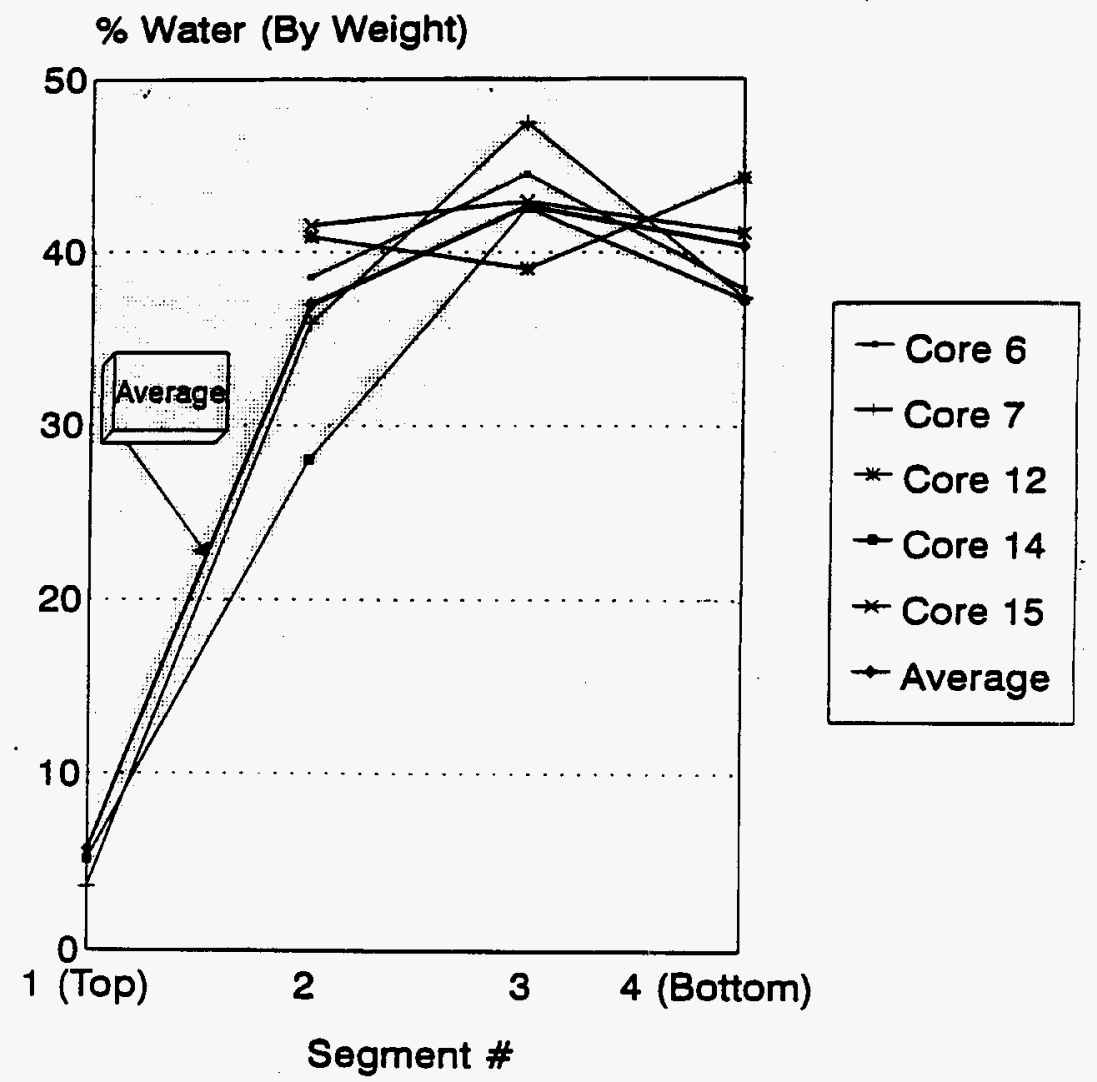


WHC-SD-WM-ER-551 Rev. 0

Figure 6-2. Uranium Trend Chart.

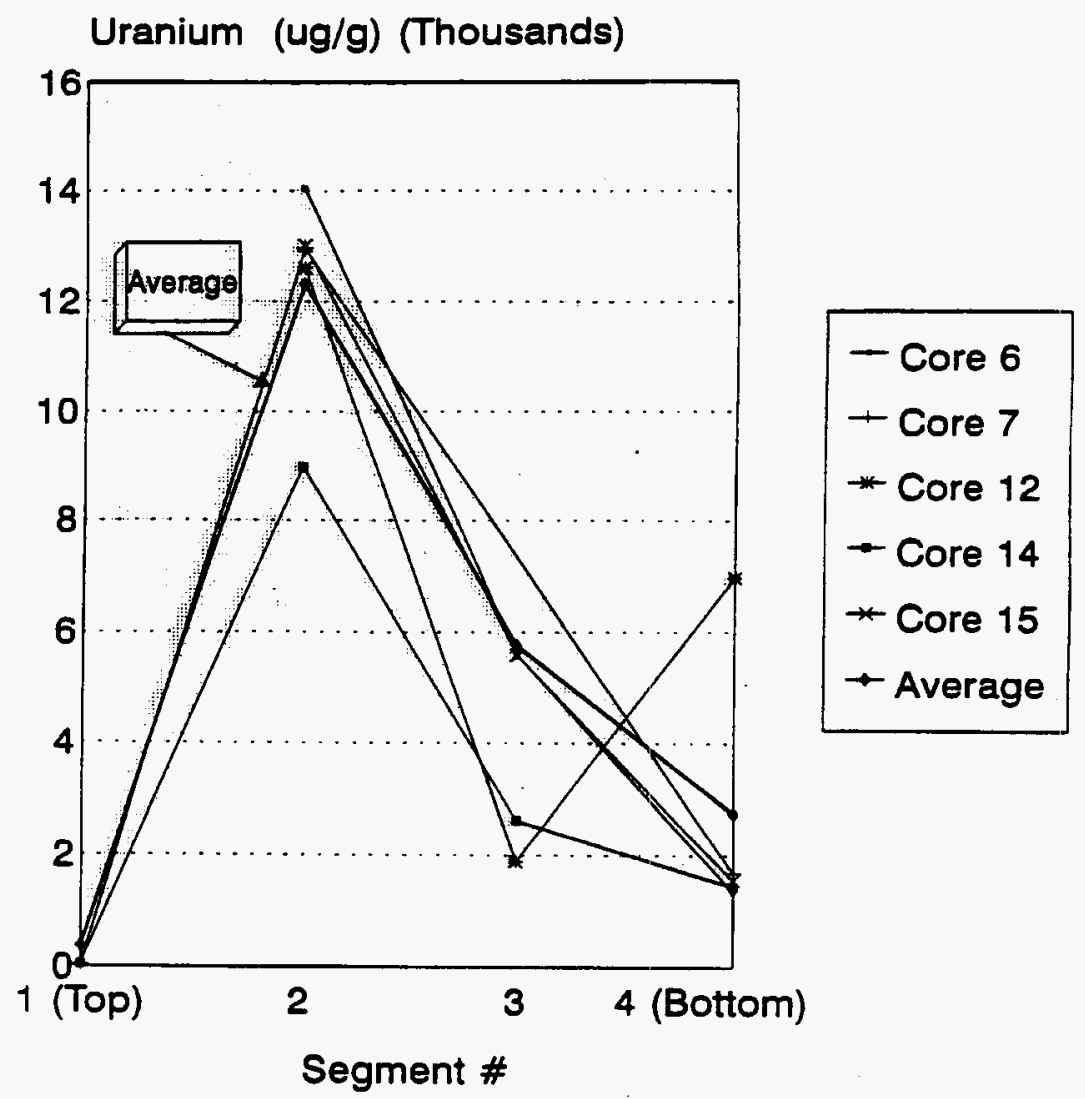


Figure 6-3. Phosphate Trend Chart.

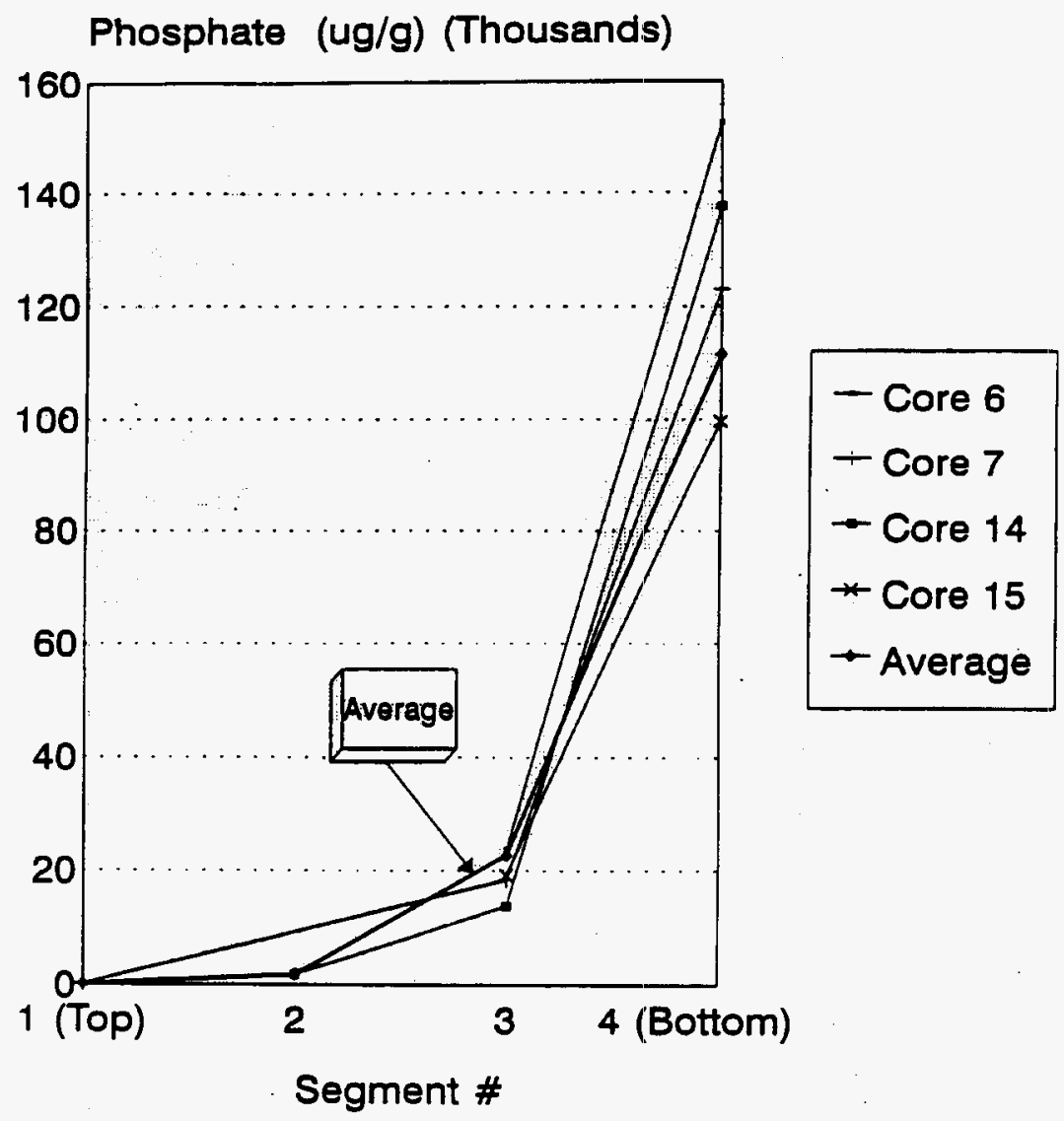


WHC-SD-WM-ER-551 Rev. 0

Figure 6-4. Aluminum Trend Chart.

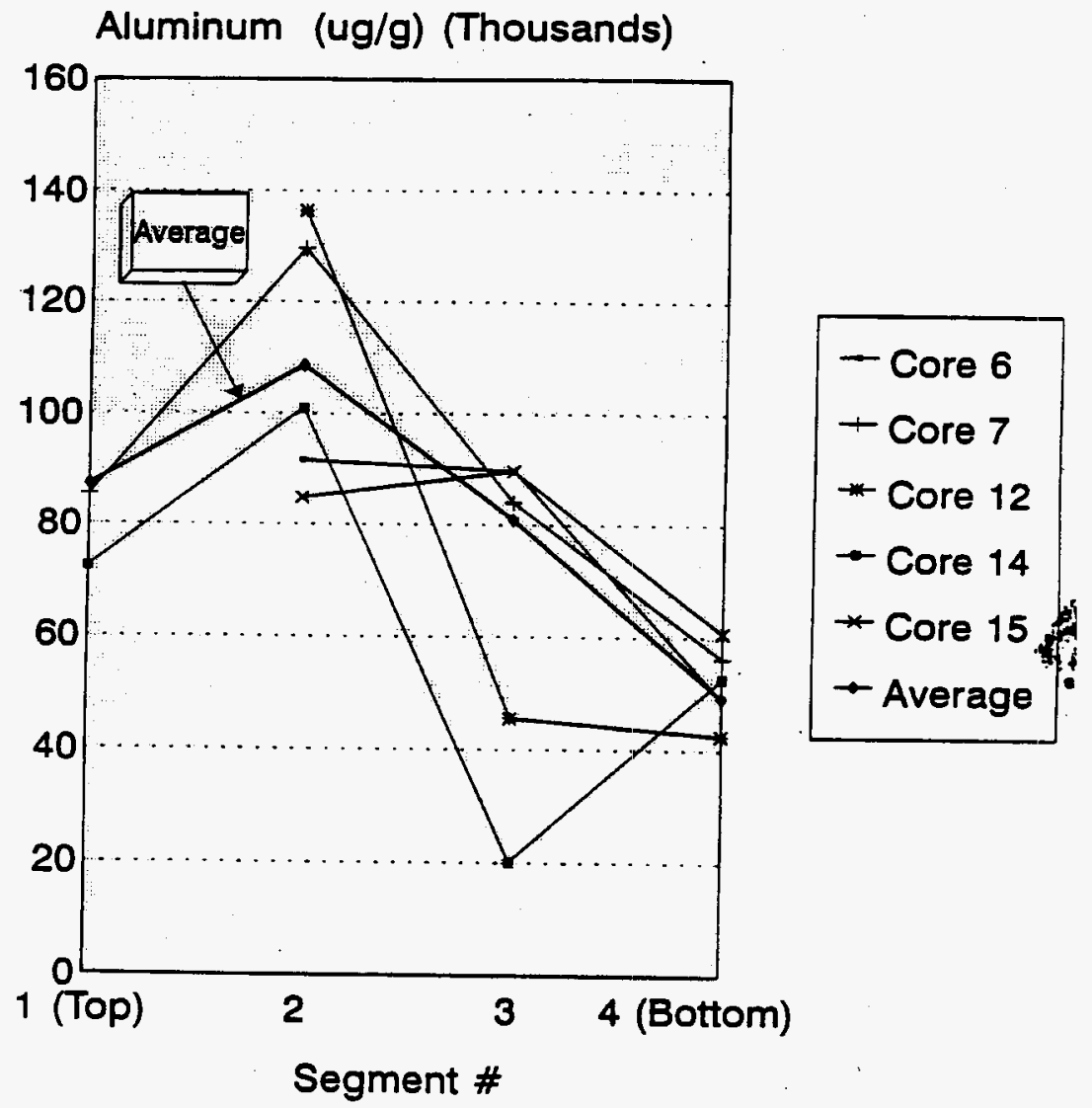


Again, it should be noted that trending values are from acid digestion ICP analysis because fusion ICP was not performed on the segments, which means that the aluminum values given on this trending table are lower than they should be. This result can be seen in core 8 segment 1 because this sample is both a segment and a composite. Core 8 shows that the acid ICP value for aluminum is $104,000 \mu \mathrm{g} / \mathrm{g}$ (i.e., 10 percent aluminum or 30 percent aluminum hydroxide equivalent) and that the fusion ICF' value is $309,000 \mu \mathrm{g} / \mathrm{g}$ (i.e., 31 percent aluminum or 92 percent aluminum hydroxide equivalent). It was stated earlier that the top segment was composed primarily of aluminum hydroxide. The acid ICP results from the segment analysis do not support this conclusion because they are low.

The reason that aluminum hydroxide has accumulated at the top of the tank waste in relatively high purity remains an enigma. Aluminum cladding waste from both the bismuth phosphate process and the REDOX process were added to the tank throughout its working lifetime. This would suggest a dispersion of aluminum hydroxide throughout the tank. The specific gravity of aluminum hydroxide is 2.42 , higher than that of sodium nitrate, sodium nitrite, and many other of the compounds that would be expected in the tank. This result would suggest that buoyancy is not the reason that aluminum hydroxide is at the top of the waste. One possibility has to do with the solubility of aluminum hydroxide. Aluminum hydroxide is amphoteric. That is, in normal conditions $(\mathrm{pH}=7)$, aluminum hydroxide is insoluble but in more acidic or alkaline conditions the substance becomes soluble and even tends to supersaturate. The average $\mathrm{pH}$ in the tank is about 12.4 , high enough to bring the aluminum hydroxide into solution. It is likely that when the tank started to dry out (at the air/liquid interface) that aluminum hydroxide was the last substance to precipitate out of solution and settle with the rest of the solid wastes before the remaining liquids were pumped, thus causing it to form on the top of the waste. This result would also explain why the $\mathrm{pH}$ in this top layer of the tank is lower than the rest of the tank. When the aluminum hydroxide precipitated from solution, it bound up much of the hydroxide into a solid form, thus causing the $\mathrm{pH}$ of the liquid solution to decrease. Another possible explanation for the lower $\mathrm{pH}$ at the top of the waste may be due to $\mathrm{CO}_{2}$ absorption at the surface.

Like most of the analytes mentioned above, sodium has a very low concentration in the first segment and a much larger concentration in the bottom three segments or sludge section of the tank. Refer to Table 6-13 and Figure 6-5 for sodium trends. The sodium probably occurs in the form of sodium salts that are dispersed throughout the darker sludge section of the waste, especially at the bottom. Most of the anions detected in this tank including fluoride, chloride, sulphate, carbonate, nitrate, and nitrite very likely occur in the form of sodium salts because sodium is the most likely major metal in the tank to form ionic bonds. A more exhaustive study of the thermodynamic properties of the tank waste components would be necessary-to further-speciate the waste.

One of the analytes that was presented in the trending tables but not on the trend charts is TC. TC is a combination of TOC and total inorganic carbon (TIC). Because organic NPH was used in the drilling operations, the estimated TOC content of the tank may not be accurate. 
WHC-SD-WM-ER-551 Rev. 0

Figure 6-5. Sodium Trend Chart.

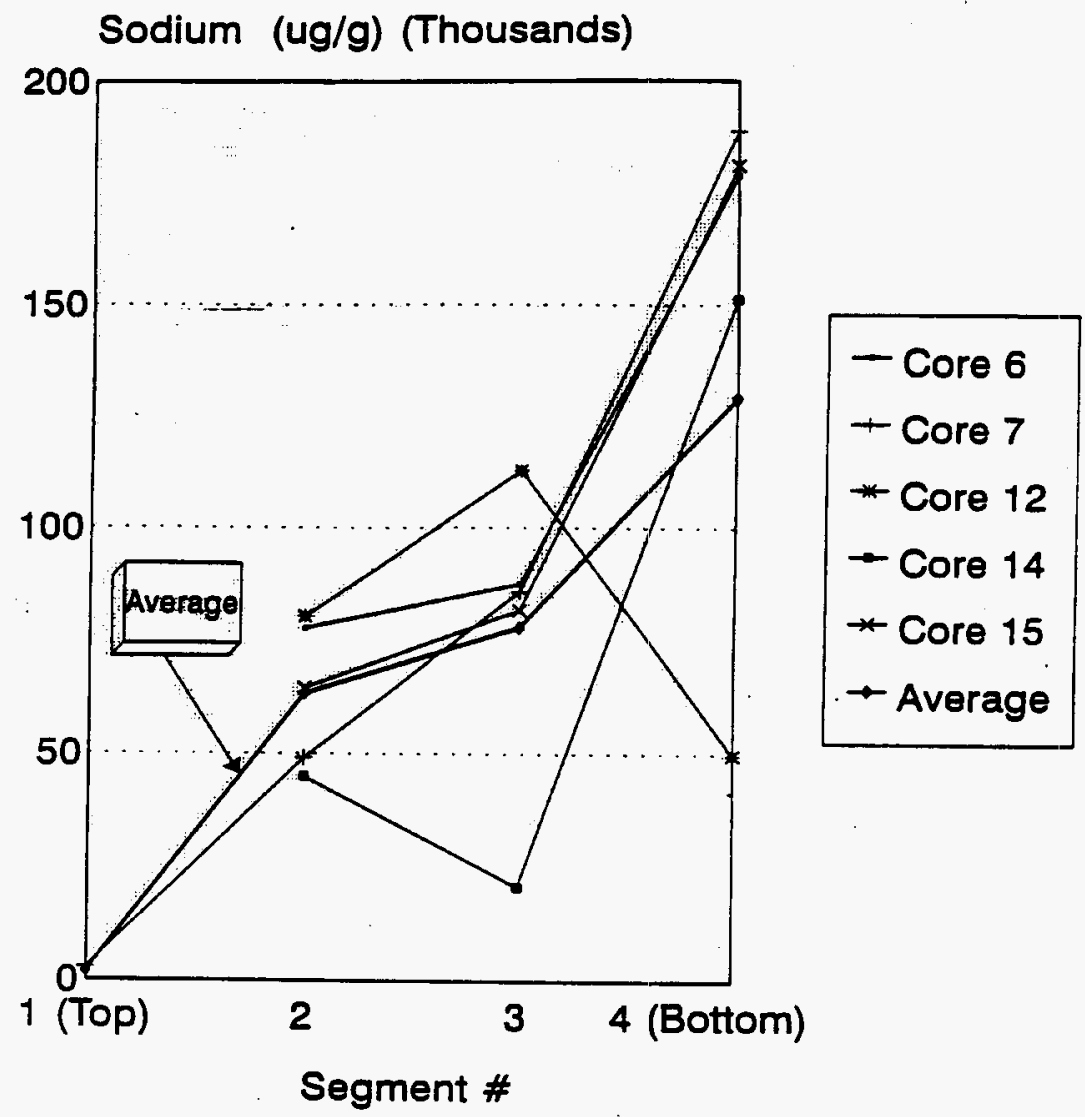




\subsection{INTERPRETATION OF COMPOSITE DATA}

The following interpretation will be performed orl composite data:

- Material balances
- Charge balances
- Comparison of water, acid, and fusion ICP data
- Comparison of historical samples to current samples.

\subsubsection{Material Balances}

A material balance is a tool used for evaluating the overall quality of data. Material balances were not considered for segment data because of the lack of fusion ICP analysis for segment samples. A material balance involves summing the individual components of a sample to make sure that the whole mass of the sample was accounted for by the laboratory analysis. To produce a material balance of the sample results, assumptions about the nature of the waste are made and then a material balance model is produced based on those assumptions. A material balance that falls short of 100 weight percent indicates that either one or more of the analyses produced a low result, a component that was not analyzed for, or that an incorrect model was used to produce the material balance. A high material balance would indicate that one or more of the analyses produced a high result or that an incorrect model was used to produce the material balance.

In analytical chemistry, material balances are used to determine the quality of the data. However, in this report, this approach will be reversed. The data will be assumed to be accurate and the material balances will be used as a tool in characterizing the contents of the tank. To accomplish this, several assumptions will be made about the nature of the contents of the tank and material balance models will be used to verify the legitimacy of these assumptions. Five different models were applied to the composite data and are found in Table 6-14. The material balances in these tables are shown as a weight percent. A model that accurately describes the contents of the tank will have an average material balance composition close to 100 percent and a small standard deviation over the different samples taken. That is to say, an accurate material balance model should add up to close to 100 weight percent consistently for all of the samples. The statistics for the composite material balances are found in Table 6-15. Because trace elements will be neglected in these models, a model that falls just short of 100 percent (i.e., 96 to 100 percent) would also be considered to be a good model.

The assumptions of the material balance models are described below. The corresponding equations for these models are given in Appendix F (Brown and Jensen 1993). 
WHC-SD-WM-ER-551 Rev. 0

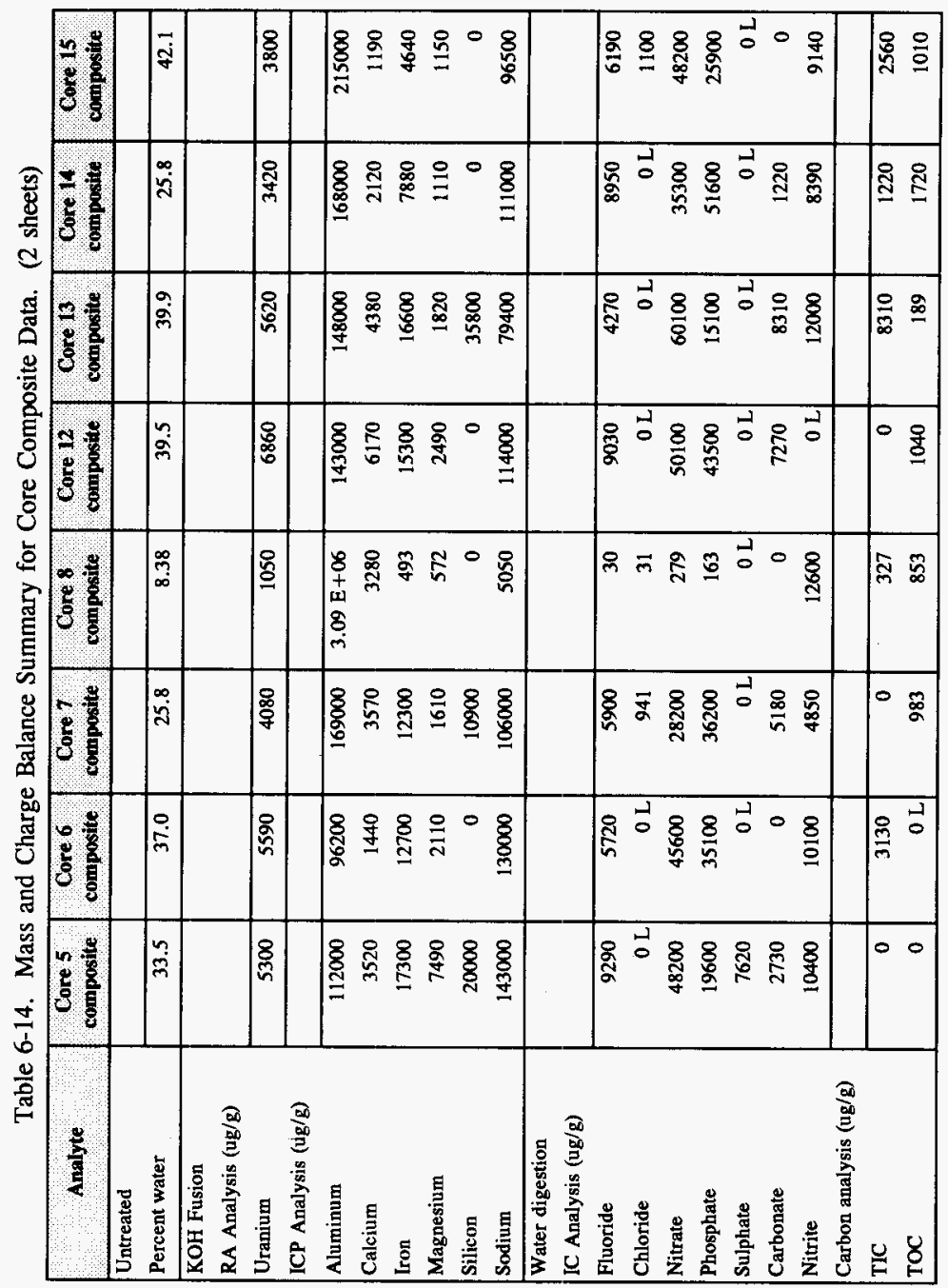


Table 6-14. Mass and Charge Balance Summary for Core Composite Data. (2 sheets)

\begin{tabular}{|c|c|c|c|c|c|c|c|c|}
\hline Analyte & $\begin{array}{l}\text { Core } 5 \\
\text { composite }\end{array}$ & Core 6 , & $\begin{array}{l}\text { Core } 7 \\
\text { composite }\end{array}$ & $\begin{array}{l}\text { Core } 8 \text {, } \\
\text { composite }\end{array}$ & $\begin{array}{l}\text { Core } 12 \\
\text { composite }\end{array}$ & Complis & $\begin{array}{l}\text { Core } 14 \\
\text { composite }\end{array}$ & $\begin{array}{l}\text { Core } 15 \\
\text { conposite }\end{array}$ \\
\hline \multicolumn{9}{|l|}{$\begin{array}{l}\text { Acid digestion } \\
\text { ICP Analysis ( } \mathrm{ug} / \mathrm{g} \text { ) }\end{array}$} \\
\hline $\begin{array}{l}\text { Bismuth } \\
\text { Manganese }\end{array}$ & $\begin{array}{r}45400 \\
5350\end{array}$ & $\begin{array}{r}20100 \\
3830\end{array}$ & $\begin{array}{r}10500 \\
2270\end{array}$ & $\begin{array}{r}0 \\
44\end{array}$ & $\begin{array}{r}0 \\
3910\end{array}$ & $\begin{array}{r}14900 \\
5490\end{array}$ & $\begin{array}{l}8320 \\
2450\end{array}$ & $\begin{array}{r}13200 \\
5300\end{array}$ \\
\hline \multicolumn{9}{|l|}{$\begin{array}{l}\text { Thermogravimetric } \\
\text { Analysis }\end{array}$} \\
\hline $\begin{array}{l}\text { \% Water } \\
\text { \% Aluminum hydroxide } \\
\text { Al(OH)3 (ug/g) } \\
\text { Al from AL }(\mathrm{OH}) 3(\mathrm{ug} / \mathrm{g})\end{array}$ & $\begin{array}{r}11.1 \\
8.18 \\
81800 \\
28300\end{array}$ & $\begin{array}{r}19.0 \\
13.1 \\
131000 \\
45300\end{array}$ & $\begin{array}{r}5.98 \\
43.7 \\
437000 \\
151000\end{array}$ & $\begin{array}{r}0 \\
76.6 \\
766000 \\
265000\end{array}$ & $\begin{array}{r}29.1 \\
0 \\
0 \\
0\end{array}$ & $\begin{array}{r}29.1 \\
0 \\
0 \\
0\end{array}$ & $\begin{array}{r}18.4 \\
29.8 \\
298000 \\
103000\end{array}$ & $\begin{array}{r}14.4 \\
11.8 \\
118000 \\
41000\end{array}$ \\
\hline \multicolumn{9}{|l|}{ Material balances } \\
\hline Model 1: & 93.5 & 85.1 & 82.9 & 69.8 & 93.2 & 103 & 83.4 & 106 \\
\hline $\begin{array}{l}\text { Model 2: (except } \mathrm{NaOH}) \\
\text { Model 2: (NaOH) } \\
\text { Model 2: Total }\end{array}$ & $\begin{array}{r}102 \\
15.4 \\
118\end{array}$ & $\begin{array}{r}87.5 \\
13.1 \\
100\end{array}$ & $\begin{array}{r}97.7 \\
9.52 \\
107\end{array}$ & $\begin{array}{r}101 \\
0.00 \\
101\end{array}$ & $\begin{array}{r}105 \\
8.21 \\
113\end{array}$ & $\begin{array}{r}119 \\
4.97 \\
124 \\
\end{array}$ & $\begin{array}{r}96.0 \\
7.79 \\
104 \\
\end{array}$ & $\begin{array}{r}123 \\
8.16 \\
131 \\
\end{array}$ \\
\hline Model 3: & 105 & 94.7 & 99.8 & 101 & 108 & 118 & 100 & 128 \\
\hline Model 4: & 97.8 & 90.3 & 98.4 & 96.3 & 93.2 & 104 & 94.0 & 111 \\
\hline $\begin{array}{l}\text { Model 5: } \\
\text { Model 5: } \\
\text { Model 5: }\end{array}$ & $\begin{array}{l}79.9 \\
15.4 \\
95.3\end{array}$ & $\begin{array}{l}69.5 \\
13.1 \\
82.6\end{array}$ & $\begin{array}{l}77.8 \\
9.52 \\
87.4\end{array}$ & $\begin{array}{r}92.5 \\
0 \\
92.2\end{array}$ & $\begin{array}{r}94.5 \\
8.21 \\
103\end{array}$ & $\begin{array}{r}108 \\
4.97 \\
113\end{array}$ & $\begin{array}{l}88.5 \\
7.79 \\
96.3\end{array}$ & $\begin{array}{r}95.6 \\
8.16 \\
104\end{array}$ \\
\hline \multicolumn{9}{|l|}{ Charge balances } \\
\hline $\begin{array}{l}\text { Model 1: Cation (meq) } \\
\text { Model 1: Anion (meq) } \\
\text { Model 1: Cation/Anion }\end{array}$ & $\begin{array}{l}21.4 \\
16.3 \\
1.31\end{array}$ & $\begin{array}{l}17.8 \\
13.1 \\
1.36\end{array}$ & $\begin{array}{l}24.6 \\
21.8 \\
1.13\end{array}$ & $\begin{array}{l}34.9 \\
34.7 \\
1.00\end{array}$ & $\begin{array}{l}22.4 \\
18.8 \\
1.19\end{array}$ & $\begin{array}{l}21.7 \\
21.2 \\
1.02\end{array}$ & $\begin{array}{l}24.4 \\
21.6 \\
1.13\end{array}$ & $\begin{array}{l}29.0 \\
26.1 \\
1.11\end{array}$ \\
\hline
\end{tabular}


Table 6-15. Statistical Summary of Mass and Charge Balance Models for Composite Data.

\begin{tabular}{|c|c|c|}
\hline & Mean & $\begin{array}{l}\text { Standard } \\
\text { deviation }\end{array}$ \\
\hline \multicolumn{3}{|l|}{ Material balances } \\
\hline Model 1: & $89.7 \%$ & $11.2 \%$ \\
\hline Model 2: & $112 \%$ & $10.6 \%$ \\
\hline Model 3: & $107 \%$ & $10.4 \%$ \\
\hline Model 4: & $98.1 \%$ & $6.23 \%$ \\
\hline Model 5: & $96.7 \%$ & $9.08 \%$ \\
\hline \multicolumn{3}{|l|}{ Charge balances } \\
\hline Model 1: Cation/Anion & 1.16 & 0.120 \\
\hline
\end{tabular}

Model 1 assumes that all of the metals are present as oxides and that the anions are present in their standard forms. Also, in this model, the TIC is assumed to be carbonate and the TOC is assumed to be acetate. The average (as found in Table 6-15) for model 1 is shown to be 89.7 percent with a standard deviation of 11.2 percent.

Model 2 assumes that all of the anions are present as sodium salts and all the metals are hydroxides except bismuth, which is in the form of bismuth phosphate. The sodium that is not present as a salt with the anions is assumed to be sodium hydroxide. As shown on Table 6-14, the first line of this model represents all of the analytes except for sodium hydroxide and the second line represents the sodium hydroxide. The amount of sodium hydroxide present is estimated by subtracting the sodium associated with the anionic salts from the total sodium in the sample. The average for this model is 112.3 percent with a standard deviation of 10.6 percent.

Model 3 is the same as model 1 (oxide model) with the exception that instead of the aluminum being present as an oxide, it is present as aluminum hydroxide. From the thermal analysis in Section 5.2, it is suspected that the upper layer and possibly even more of the aluminum in the tank is in the form of aluminum hydroxide. The average for this model is 106.8 percent, slightly-closer-than-the-previous-two-models. - The standard deviation is 10.4 percent.

Model 4 is the same as model 1 (oxide model) with the exception that some percentage of the aluminum is present as a hydroxide and some percentage is present as an oxide. To make the distinction, the amount of aluminum existing as aluminum hydroxide is calculated from the aluminum hydroxide peak of the thermogravimetric analysis discussed in 
Section 5.2. The remainder is assumed to be aluminum oxide and is calculated from the difference of the total aluminum and the aluminum from aluminum hydroxide. Another difference with this model is that bismuth is assumed to come in the form of bismuth phosphate instead of oxide. This assumption led to the closest model result of 98.1 percent with a standard deviation of 6.2 percent.

The final model, model 5, resembles model 2 (hydroxide model) except that the water is calculated from the thermogravimetric water loss taken from the thermogravimetric analysis in Section 5.2. The average for this model is 96.6 percent with a standard deviation of 9.1 percent.

The model that best depicts the waste in the tank is model 4. This model would indicate that most of the metals occur in their oxide form except aluminum, which can occur as an oxide or a hydroxide, and bismuth, which is most likely a phosphate. Because of the high alkalinity of the tank, the chance that many of the metals are in a hydroxide form should not be discredited. One possible reason that the hydroxide model (model 2) gives a high material balance is because of the possibility that the percent water analysis might be high. The water analysis is performed by drying the sample in an oven overnight at a temperature slightly over $100^{\circ} \mathrm{C}$. This method is different than the thermogravimetric method of water detection where the sample is heated quickly with a constant rise in temperature. If the waste contained a high amount of metal hydroxides or hydrates, it is possible that many of these metal hydroxides and hydrates would dehydrate if left at high temperatures for a long period of time, thus causing the percent water reading to be high. For this reason, the thermogravimetric percent water reading was used in model 5 with the hydroxide model. The thermogravimetric method dries the waste faster thus allowing less of a chance for the metal hydroxides or hydrates to dehydrate. It is for the data user to choose which model, if any, should be used to characterize the contents of the tank. Another possibility that was not considered in the mass balance is that the aluminum that does not occur in the form of aluminum hydroxide $\left(\mathrm{Al}(\mathrm{OH})_{3}\right)$ may occur in the tank in the form of aluminum hydroxide $(\mathrm{AlOOH})$, also known as boehmite.

\subsubsection{Charge Balances}

The second tool used in the interpretation of the composite data is the charge balance. The positive charge associated with the anions should equal the negative charge of the cations or the ratio of the two should equal one. As with the material balance, an assumption was made and a charge balance model was created. This model is shown in Appendix F (Brown and Jensen 1993) and the-results-are-shown in-Table-6-1.4 with the material balance models. The statistical summary for the charge balance model is shown in Table 6-15. Only one model was suggested and the information gained from the charge balance model is less conclusive than for the material balances. The reason for this is that the concentration of oxides or of hydroxides are not known and are needed to balance the charges. 


\subsubsection{Comparison of Water, Acid, and Fusion ICP Data}

Another important consideration when interpreting the data is the difference between water, acid, and fusion ICP data. Unlike the segment clata, the composite data included ICP analyses from all three methods of digestion. All three methods have merit and it is important to understand when each should be used.

The first point to be made is the difference between acid and fusion ICP analysis (see Section 6.1). Fusion analysis is more accurate with abundant occurring analytes, also referred to as the major metals. These metals were recognized earlier as being aluminum, calcium, magnesium, iron, silicon, and sodium. Fusion ICP analysis should be used when the fusion ICP results are larger and also more consistent than the acid results. Acid ICP results should be used for any other metal to offer a method of analyzing trace metals or any other substance that is undetectable in the high dilutions of the fusion analysis. Nickel and potassium should also be analyzed with the acid ICP analysis because these metals are used in the fusion dissolution process. Uranium should not be analyzed using ICP because it produces interferences. Instead, uranium should be detected from the fusion prepared radiological analysis (fluorimetry).

The second point is the difference between the fusion and acid ICP results and the water results. Fusion and acid generally bring both the soluble and the insoluble solid components of an analyte into solution. Water digestion, on the other hand, brings only the water-soluble components into solution. The only two metals that register on the water ICP to any appreciable degree are aluminum and sodium. About 75 percent of the sodium in the tank is water soluble. This strengthens the hypothesis made in Section 6.4 that most of the sodium in the tank has formed an ionic bond with the major anions to form sodium salts. All of these possible sodium salts are either mildly or highly water soluble. Sodium hydroxide, another likely form of the sodium, is also water soluble. Also, about 2 percent of the aluminum appears in a soluble form. It was speculated earlier that most of the aluminum appears in the insoluble form, possibly as aluminum oxide or aluminum hydroxide, which indicates that a small percentage is soluble, for example sodium aluminate.

\subsubsection{Verification of Indicator Analytes}

In this section, a brief discussion of the expected indicator analytes will be given. In Section 2.0, a list of analytes was presented that were expected to be found in the tank based on its history. These analytes were referred to as indicator analytes and are listed in Table 2-6. The list-does not show-analytes that-were-expected to be-found in the tank in the greatest abundance but a list of analytes that are distinctive to tank U-110. That is, these analytes are characteristic of the types of waste that went into tank U-110. 
The first two indicators listed are bismuth and phosphate. It was verified in Section 6.4 that both of these analytes occur in abundarice, especially at the bottom of the tank. The next indicator was aluminum; next to water, aluminum is the most predominant analyte in tank $\mathrm{U}-110$.

Chrome is the fourth indicator given on the list. Chrome occurs in the tank at approximately $500 \mu \mathrm{g} / \mathrm{g}$. Relative to the major metals, the concentration of chrome in the tank is small because only a small amount of chrome was present from the REDOX process in $R$ waste. The existence of the chrome is still a good indication that the tank received $\mathrm{R}$ waste.

The last indicator is fluoride. As shown in Section 6.4, fluoride is found in abundance in the tank, especially at the bottom of the waste.

The verification of these indicator analytes supports the historical supposition of the waste types that were stored in tank U-110. The evidence of $1 \mathrm{C}$ waste from the bismuth phosphate process being stored in the tank is very conclusive. High concentrations of aluminum throughout the tank as well as bismuth and phosphate in abundance at the bottorn of the tank support this hypothesis very well. The existence of chrome in the tank also sustains the disposal of a lesser amount of R (REDOX) waste as well. The high amount of aluminum also indicates that REDOX aluminum cladding waste was stored in the tank.

\subsection{COMPARISON OF HISTORICAL SAMPLES TO CURRENT SAMPLES}

A comparison of historical samples taken in the mid 1970's reveals much about the nature of the tank waste. In 1974, a solid sludge sample was taken from the tank and analyzed. In 1975, a liquid supernate sample was also taken and analyzed. The compositions of both of these samples are given in Table 2-7.

The supernate sample taken in 1975 was a light yellow liquid with a water-like density. The sample was composed of approximately 98 percent water. Like the current samples, the thermal analysis revealed no exothermic reaction. This historical sample analysis also supported the conclusion that sodium and nitrate are the major soluble analytes in the tank and that the aluminum is primarily insoluble.

The sludge sample taken in 1974 offers a much more valuable historical to current comparison of the tank waste. This is because it was the same type of sample as those samples taken in-1989 for the-current characterization-effort. The 1974 samples were described as being a brown, mud-like sludge, which is similar to the description given for the waste samples in segments two through four (the bottom two layers of the tank waste). The high nitrate content of the 1974 sample $(221,000 \mu \mathrm{g} / \mathrm{g})$ and the high water content (44.3 percent) further indicates that this historical sample contains sludge waste and not waste from the top aluminum hydroxide layer. This indicates that either the sample was 
taken from a spot below the surface of the waste or that the white aluminum hydroxide layer in the tank had not yet formed.

In Table 6-16, several important analytes detected in the 1974 historical sample (Table 2-7) are compared with the current range of those analytes in the tank. This range is presented as the lower and upper 95 percent confidence interval. That is to say, there is 95 percent confidence that the current average concentration of any given analyte is within this range. The estimated average current concentration is also given in this table. These confidence intervals are calculated in Section 7.4 .

Table 6-16. Historical Samples Versus Current Samples.

\begin{tabular}{|c|c|c|c|c|c|}
\hline Analyte & Units & $\begin{array}{l}\text { Historical } \\
\text { concentration } \\
\text { August } 1974\end{array}$ & $\begin{array}{l}\text { Current: lower } \\
95 \text { percent } \\
\text { confidence }\end{array}$ & $\begin{array}{l}\text { Cument: } \\
\text { average } \\
\text { concentration }\end{array}$ & $\begin{array}{l}\text { Current: } \\
\text { upper } \\
95 \text { percent } \\
\text { confidence }\end{array}$ \\
\hline Water & percent & 44.3 & N/A & 40.0 & N/A \\
\hline $\mathrm{Al}$ & $\mu \mathrm{g} / \mathrm{g}$ & 135,000 & 114,000 & 150,000 & 187,000 \\
\hline $\mathrm{Fe}$ & $\mu \mathrm{g} / \mathrm{g}$ & 9,710 & 8,070 & 12,400 & 16,700 \\
\hline $\mathrm{NO}_{2}$ & $\mu \mathrm{g} / \mathrm{g}$ & 613 & 6,580 & 9,150 & 11,700 \\
\hline $\mathrm{NO}_{3}$ & $\mu \mathrm{g} / \mathrm{g}$ & 221,000 & 35,500 & 45,100 & 54,800 \\
\hline $\mathrm{CO}_{3}$ & $\mu \mathrm{g} / \mathrm{g}$ & 55,600 & 1,900 & 4,350 & 6,790 \\
\hline $\mathrm{PO}_{4}$ & $\mu \mathrm{g} / \mathrm{g}$ & 41,200 & 20,400 & 32,400 & 44,500 \\
\hline${ }^{89,90} \mathrm{Sr}$ & $\mu \mathrm{Ci} / \mathrm{g}$ & 1,390 & 251 & 367 & 482 \\
\hline${ }^{137} \mathrm{Cs}$ & $\mu \mathrm{Ci} / \mathrm{g}$ & 85.6 & 15.6 & 28.2 & 40.8 \\
\hline $\begin{array}{c}\text { Bulk } \\
\text { density }\end{array}$ & $\mathrm{g} / \mathrm{mL}$ & 1.50 & N/A & 1.46 & N/A \\
\hline
\end{tabular}

It is seen that both the water content and the bulk density of the historical sample very closely resemble that of the current sludge samples. As well, the historical aluminum, iron, and phosphate concentrations are also within the current range for those analytes. However, the nitrate, nitrite, carbonate, and the fission products cesium and strontium are not within the current range. Possible reasons for these discrepancies, aside from the possibility of analytical error,-are-discussed-below.

In the historical sample, the nitrate has a concentration almost five times that of the current samples. However, the nitrite level is much lower in the historical sample than in the current sample. This suggests that the nitrate is reducing to nitrite and other possible compounds (such as $\mathrm{N}_{2} \mathrm{O}$ gas) over a period of time. 
The fission products cesium and strontium are both significantly smaller in the current sample than in the historical sample (in the order of one third to one fourth the concentration of the historical sample). Because the half lives of both cesium and strontium are approximately 30 years, some reduction is expected in the current samples. Because the amount of time between these samples is only 15 years, the amount of reduction should be less than one half. Hence, this does not explain why the current samples are one third to one fourth the concentration of the 1974 sample. One other possible reason is that there could possibly have been a large amount of heterogeneity in the historical sample.

The carbonate was approximately ten times more concentrated in 1974 than the current sample. This is difficult to explain except that it may have washed out with the laboratory waste transfers and supernate pumping that occurred in the last active years of the tank. 
WHC-SD-WM-ER-551 Rev. 0

This page intentionally left blank. 


\subsection{STATISTICAL ANALYSIS - CONCENTRATION ESTIMATES OF TANK U-110 ANALYTES}

This section contains estimates of the mean concentration and confidence intervals on the mean concentration of various analytes in tank U-110. The concentration estimates are based on observations from incomplete core samples; consequently, the results given may be biased, and the magnitude of that bias cannot be evaluated. However, if it is assumed that the core and segment samples that were recovered constitute a random sample from the SST, then the concentration estimates given are unbiased. The data in this report were evaluated as if the recovered segments were a random sample.

This section was taken directly from the report Statistical Characterization Report for Single-Shell Tank 241-U-110 (Jensen and Remund 1993).

\subsection{INTRODUCTION}

A task outlined in the Waste Characterization Plan for Tank $U-110$ was to estimate the inventory of various analytes found in the tank. The inventory was to be based upon the chemical analyses of the core composite sample formed from each core (Winters 1990). This section reports the results of a statistical analysis of the core composite sample data.

Analytical concentration data from the seven tank $\mathrm{U}-110$ core samples were used to estimate the concentration of the various analytes found in the waste. Each core consisted of four segments. The recovered core segments were homogenized, and a composite sample, representing each core, was formed. The composite sample was formed by combining individual samples from each homogenized segment. The core composite samples were constructed from incomplete segments; therefore the composite samples may be a biased representation of the complete core.

The core composite sample was also homogenized. Two aliquots were drawn from each core composite sample and prepared for chemical analysis. For each analyte, the concentration estimates were computed based upon these pairs of data.

Two assumptions must be valid to estimate the mean composition of the waste in tank U-110 based upon the chemical analysis of core composite samples.

- The 222-S Laboratory can homogenize and sample individual segments.

- The 222-S Laboratory can combine and rehomogenize samples from the segments to form the core composite sample.

If these two assumptions are valid, the composite sample will represent the entire core. Both assumptions are analyzed and addressed in Section 7.5. Based upon the results in these analyses, both assumptions are valid. 
The statistical results in this section are based upon the chemical analysis results of the core composite samples; an alternative method is to use the results from the individual segments. Because the core and segment recovery was incomplete (see Figure 3-1), the concentration estimates are based on the results from the composite samples.

\subsection{CONCENTRATION ESTIMATES}

The concentration data from the seven core composite samples are given in Tables G-1, G-2, and G-3 of Appendix G, Brown and Jensen 1993. The "LT" abbreviation in the tables means that the chemical analysis result was less than the detection limit. The "NA" abbreviation means that the result was not available. Such observations were omitted from all computations.

If an LT is treated as a missing value, the final mean concentration estimates and confidence intervals are biased. An alternative procedure is to replace the LT by some value, such as $\mathbf{0}$, or the detection limit, or one-half of the detection limit. The use of any of these alternative values also results in biased estimates.

Tables 7-1, 7-3, and 7-5 give the mean concentration of the analytes in tank U-110. The concentration estimates for each of the analytes found in the SST are the mean concentration and 95 percent confidence intervals on the mean concentration. The computational formulas for the confidence intervals are given in the theory section of Appendix G, Brown and Jensen 1993. These formulas are based upon the results from a one-way analysis of variance associated with the hierarchical structure of the data.

Tables 7-1, 7-3, and 7-5 contain the following summary statistics:

- $\bar{y} \quad=$ arithmetic mean of the concentration data

- BMS = "between mean square" from the one-way analysis of variance

- $\hat{\sigma}^{2}(\bar{y})=$ estimated variance of $\bar{y}$

- df $=$ degrees of freedom associated with BMS

- $\mathrm{L}=$ lower limit to the 95 percent confidence interval on the mean

- $\mathrm{U}=$ upper limit to the 95 percent confidence interval on the mean.

For some analytes, the lower limit (LL) of the confidence interval was negative. Because concentrations are strictly greater than or equal to zero, any negative value for $\mathrm{L}$ was set equal to zero.

For the confidence interval expressed as a percent of the mean concentration, see Tables 7-2, 7-4, and 7-6. These tables give the confidence interval as $\bar{y} \pm C L$, where the confidence limit (CL) is a percent of $\bar{y}$. The percent values range between 4 percent and 205 percent. The magnitude of these values give an indication of the heterogeneity of the waste. 
WHC-SD-WM-ER-551 Rev. 0

Table 7-1. Acid Digestion Statistics.

\begin{tabular}{|c|c|c|c|c|c|c|c|}
\hline \multicolumn{2}{|c|}{$\begin{array}{l}\text { Method and } \\
\text { analyte }\end{array}$} & y & BMS & $\hat{\sigma}^{2}(\hat{g})$ & df & $\mathbf{L}$ & $\mathbf{v}$ \\
\hline \multirow{3}{*}{$\begin{array}{l}\mathrm{AAS} \\
(\mu \mathrm{g} / \mathrm{g})\end{array}$} & As & 0.408 & 0.00170 & 0.000283 & 2 & 0.336 & $0.48 \mathrm{i}$ \\
\hline & $\mathrm{Hg}$ & 2.96 & 68.6 & 4.90 & 6 & 0.00 & 8.38 \\
\hline & $\mathrm{Se}$ & 1.77 & 5.16 & 0.570 & 4 & 0.00 & 3.87 \\
\hline \multirow{30}{*}{$\begin{array}{l}\mathrm{ICP} \\
(\mu \mathrm{g} / \mathrm{g})\end{array}$} & $\overline{\mathrm{Al}}$ & 90900 & $1.79 \mathrm{E}+09$ & $1.28 \mathrm{E}+08$ & 6 & 63300 & 119000 \\
\hline & As & 171 & 365 & 61 & 2 & 137 & 204 \\
\hline & $\mathrm{Ba}$ & 64 & 4560 & 3.80 & 6 & 16 & 112 \\
\hline & $\mathrm{Be}$ & 3.2 & 1.29 & 0.140 & 6 & 2.2 & 4.1 . \\
\hline & $\mathrm{Bi}$ & 18700 & $3.72 \mathrm{E}+08$ & $3.10 \mathrm{E}+07$ & 5 & 4410 & 33100 \\
\hline & B & 69 & 779 & 71.0 & 5 & 48 & 91 \\
\hline & $\mathrm{Ca}$ & 494 & 31100 & 2220 & 6 & 379 & 610 \\
\hline & $\mathrm{Cr}$ & 612 & 197000 & 14000 & 6 & 323 & 902 \\
\hline & $\mathrm{Cu}$ & 134 & 11900 & 1190 & 6 & 50 & 219 \\
\hline & $\mathrm{Fe}$ & 12600 & $3.19 \mathrm{E}+07$ & $2.28 \mathrm{E}+06$ & 6 & 8860 & 16200 \\
\hline & $\mathrm{Pb}$ & 866 & 497000 & 414.00 & 5 & 343 & 1390 \\
\hline & Mg & 647 & 515000 & 36800 & 6 & 177 & 1120 \\
\hline & Mn & 4080 & $3.70 \mathrm{E}+06$ & 2650100 & 6 & 2830 & 5340 \\
\hline & $\mathrm{Hg}$ & 477 & 155000 & 141000 & 5 & 172 & 782 \\
\hline & Mo & 49 & 414 & 38.0 & 6 & 34 & 64 \\
\hline & $\mathrm{Ni}$ & 124 & 2370 & 182 & 6 & 91 & $15 \%$ \\
\hline & $\mathbf{P}$ & 15300 & $1.14 \mathrm{E}+08$ & $1.14 \mathrm{E}+07$ & 4 & 5900 & 24700 \\
\hline & $\mathrm{Se}$ & 779 & 196000 & 15100 & 6 & 479 & 1080 \\
\hline & $\mathrm{Si}$ & 3770 & 183000 & 45700 & 1 & 1060 & 6490 \\
\hline & $\mathrm{Na}$ & 93300 & $1.63 \mathrm{E}+09$ & $1.17 \mathrm{E}+08$ & 6 & 66800 & 120000 \\
\hline & $\mathrm{Sr}$ & 490 & 49900 & 3570 & 6 & 344 & 636 \\
\hline & $s$ & 710 & 793000 & 56700 & 6 & 128 & 1290 \\
\hline & $\mathrm{Tl}$ & 3080 & $4.50 \mathrm{E}+06$ & 500000 & 5 & 1260 & $4900)$ \\
\hline & Th & 1790 & $1.49 \mathrm{E}+06$ & 1660100 & 5 & 748 & 2840 \\
\hline & Sn & 114 & 2020 & 184 & 6 & 81 & 147 \\
\hline & $\mathrm{Ti}$ & 55 & 881 & 73.0 & 6 & 34 & 76 \\
\hline & $\mathrm{U}$ & 11000 & $4.26 E+06$ & 609000 & 4 & 8820 & 13200 \\
\hline & $\mathrm{V}$ & 67 & 391 & 43.0 & 5 & 50 & 84 \\
\hline & $\mathrm{Zn}$ & 312 & 269000 & 19200 & 6 & 0 & $65 \|$ \\
\hline & $\mathrm{Zr}$ & 169 & 3140 & 314 & 6 & 126 & 213 \\
\hline
\end{tabular}

AAS = Atomic Absorption Spectroscopy Analysis ICP = Inductively Coupled Plasma Analysis. 
WHC-SD-WM-ER-551 Rev. 0

Table 7-2. Acid Digestion, Confidence Limits as Percent of the Mean.

\begin{tabular}{|c|c|c|c|}
\hline \multicolumn{2}{|c|}{ Method and analyte } & $\bar{y}$ & CL (\%) \\
\hline AAS $(\mu \mathrm{g} / \mathrm{g})$ & $\begin{array}{l}\mathrm{As} \\
\mathrm{Hg} \\
\mathrm{Se}\end{array}$ & $\begin{array}{r}0.408 \\
2.96 \\
1.77\end{array}$ & $\begin{array}{c}18.0 \\
183 \\
119\end{array}$ \\
\hline ICP $(\mu \mathrm{g} / \mathrm{g})$ & 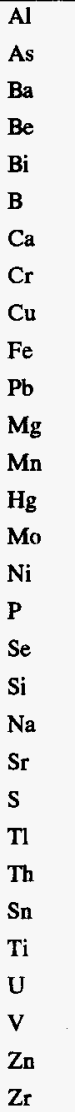 & $\begin{array}{r}90900 \\
171 \\
64 \\
3.2 \\
18700 \\
69 \\
494 \\
612 \\
134 \\
12600 \\
866 \\
647 \\
4080 \\
477 \\
49 \\
124 \\
15300 \\
779 \\
3770 \\
93300 \\
490 \\
710 \\
3080 \\
1790 \\
114 \\
55 \\
11000 \\
.67 \\
312 \\
169\end{array}$ & $\begin{array}{l}30.0 \\
20.0 \\
74.0 \\
29.0 \\
76.0 \\
31.0 \\
23.0 \\
47.0 \\
63.0 \\
29.0 \\
60.0 \\
73.0 \\
31.0 \\
64.0 \\
31.0 \\
27.0 \\
61.0 \\
39.0 \\
72.0 \\
28.0 \\
30.0 \\
82.0 \\
59.0 \\
58.0 \\
29.0 \\
38.0 \\
20.0 \\
25.0 \\
109 \\
26.0\end{array}$ \\
\hline
\end{tabular}

AAS $=$ Atomic Absorption Spectroscopy Analysis

$\mathrm{CL}=\mathrm{t} * \hat{\sigma}(\overline{\mathrm{y}}) * 100 / \overline{\mathrm{y}}$

ICP = Inductively Coupled Plasma Analysis. 
Table 7-3. KOH Fusion Dissolution Statistics.

\begin{tabular}{|c|c|c|c|c|c|c|c|}
\hline \multicolumn{2}{|c|}{ Method and analyte } & $\bar{y}$ & BMS & $\sigma^{2}(\mathrm{y})$ & df & L & $\mathrm{U}$ \\
\hline \multirow[t]{7}{*}{$\mathrm{RA}(\mu \mathrm{Ci} / \mathrm{g})$} & Total $\alpha$ & 0.164 & 0.000949 & 0.000158 & 2 & 0.110 & 0.218 \\
\hline & Total $\beta$ & 1010 & 318000 & 22700 & 6 & 641 & 1380 \\
\hline & Cs-137 & 28.2 & 371 & 26.5 & 6 & 15.6 & 40.8 \\
\hline & $\mathrm{U}(\mu \mathrm{g} / \mathrm{g})$ & 4950 & $3.01 \mathrm{E}+06$ & 215000 & 6 & 3820 & 60190 \\
\hline & Pu-239/240 & 0.250 & 0.0130 & 0.00100 & 6 & 0.176 & 0.325 \\
\hline & Am-241 & 0.0871 & 0.00180 & 0.000152 & 5 & 0.0554 & 0.1 .19 \\
\hline & Sr-90 & 367 & 24100 & 2010 & 5 & 251 & $4 \mid 82$ \\
\hline \multirow[t]{17}{*}{ ICP $(\mu \mathrm{g} / \mathrm{g})$} & $\mathrm{Al}$ & 150000 & $3.09 \mathrm{E}+09$ & $2.21 \mathrm{E}+08$ & 6 & 114000 & 187000 \\
\hline & $\mathrm{Bi}$ & 20600 & $2.99 \mathrm{E}+08$ & $2.49 \mathrm{E}+07$ & 5 & 7810 & 33500 \\
\hline & B & 3430 & $2.91 \mathrm{E}+07$ & $2.64 \mathrm{E}+06$ & 6 & 0 & 74100 \\
\hline & $\mathrm{Ca}$ & 3200 & $6.25 \mathrm{E}+06$ & 447000 & 6 & 1560 & $48: 30$ \\
\hline & $\mathrm{Cr}$ & 535 & 105000 & 13100 & 3 & 172 & 899 \\
\hline & $\mathrm{Fe}$ & 12400 & $4.37 \mathrm{E}+07$ & $3.12 \mathrm{E}+06$ & 6 & 8070 & 16700 \\
\hline & $\mathrm{Pb}$ & 1090 & 301000 & 37600 & 3 & 474 & 1710 \\
\hline & $\mathbf{M g}$ & 2540 & $1.00 \mathrm{E}+07$ & 0.0000716 & 6 & 471 & 46,10 \\
\hline & Mn & 3460 & $2.78 \mathrm{E}+06$ & 198000 & 6 & 2370 & 4550 \\
\hline & $\mathrm{Ni}$ & 6660 & $2.31 \mathrm{E}+06$ & 165000 & 6 & 5660 & 7650 \\
\hline & $\mathrm{Se}$ & 1260 & 113000 & 18800 & 3 & 821 & 1690 \\
\hline & $\mathrm{Si}$ & 22200 & $3.16 \mathrm{E}+08$ & $5.26 \mathrm{E}+07$ & 2 & 0 & 53500 \\
\hline & $\mathrm{Na}$ & 111000 & $8.75 \mathrm{E}+08$ & $6.25 \mathrm{E}+07$ & 6 & 92000 & 131000 \\
\hline & $\mathrm{Sr}$ & 505 & 56100 & 4010 & 6 & 350 & 659 \\
\hline & $s$ & 846 & 386000 & 29700 & 6 & 425 & 1270 \\
\hline & $\mathrm{Zn}$ & 1080 & $8.76 \mathrm{E}+06$ & 626000 & 6 & 0 & 3010 \\
\hline & $\mathrm{Zr}$ & 372 & 20000 & 4000 & 2 & 100 & 644 \\
\hline
\end{tabular}

ICP = Inductively Coupled Plasma Analysis

RA = Radiological Analysis. 
WHC-SD-WM-ER-551 Rev. 0

Table 7-4. Fusion Dissolution, Confidence Limits as Percent of the Mean.

\begin{tabular}{|l|l|r|c|}
\hline \multicolumn{2}{|c|}{ Method and analyte } & \multicolumn{1}{|c|}{ CL } & (\%) \\
\hline RA $(\mu \mathrm{Ci} / \mathrm{g})$ & Total A & 0.164 & 33.0 \\
& Total B & 1010 & 36.0 \\
& Cs 137 & 28.2 & 45.0 \\
& U & 4950 & 23.0 \\
& Pu-239/240 & 0.250 & 30.0 \\
& Am 241 & 0.0871 & 36.0 \\
& Sr 90 & 367 & 31.0 \\
\hline ICP $(\mu \mathrm{g} / \mathrm{g})$ & $\mathrm{Al}$ & 150000 & 24.0 \\
& $\mathrm{Bi}$ & 20600 & 62.0 \\
& $\mathrm{~B}$ & 3430 & 116 \\
& $\mathrm{Ca}$ & 3200 & 51.0 \\
& $\mathrm{Cr}$ & 306 & 90.0 \\
& $\mathrm{Fe}$ & 12400 & 35.0 \\
& $\mathrm{~Pb}$ & 1090 & 57.0 \\
& $\mathrm{Mg}$ & 2540 & 81.0 \\
& $\mathrm{Mn}$ & 3460 & 31.0 \\
& $\mathrm{Ni}$ & 6660 & 15.0 \\
& $\mathrm{Se}$ & 1260 & 35.0 \\
& $\mathrm{Si}$ & 22200 & 140 \\
& $\mathrm{Na}$ & 111000 & 17.0 \\
& $\mathrm{Sr}$ & 505 & 31.0 \\
& $\mathrm{~S}$ & 846 & 50.0 \\
& $\mathrm{Zn}$ & 1080 & 179 \\
& $\mathrm{Zr}$ & 372 & 73.0 \\
\hline
\end{tabular}

$\mathrm{CL}=\mathrm{t}^{*} \hat{\sigma}(\overline{\mathrm{y}})^{*} 100 / \overline{\mathrm{y}}$

ICP = Inductively Coupled Plasma Analysis

$\mathrm{RA}=$ Radiological Analysis. 
WHC-SD-WM-ER-551 Rev. 0

Table 7-5. Water Digestion Statistics.

\begin{tabular}{|c|c|c|c|c|c|c|c|}
\hline \multicolumn{2}{|c|}{ Method and analyte } & \multirow{2}{*}{$\frac{t+1}{11.4}$} & \multirow{2}{*}{$\frac{\mathrm{BMS}}{0.493}$} & \multirow{2}{*}{$\frac{\hat{\sigma}^{2}(\bar{y})}{0.035}$} & \multirow{2}{*}{$\frac{d f}{6}$} & \multirow{2}{*}{\begin{tabular}{|l|}
$\mathrm{L}$ \\
11.0
\end{tabular}} & \multirow{2}{*}{$\frac{\mathrm{U}}{11.9}$} \\
\hline UA & $\mathrm{pH}$ & & & & & & \\
\hline \multirow[t]{5}{*}{ IC $(\mu \mathrm{g} / \mathrm{g})$} & $\mathbf{F}$ & 7050 & $8.05 \mathrm{E}+06$ & 575000 & 6 & 5200 & 8910 \\
\hline & $\mathrm{Cl}$ & 1020 & 25000 & 6240 & 1 & 16 & 2020 \\
\hline & $\mathrm{NO}_{3}$ & 45100 & $2.17 \mathrm{E}+08$ & $1.55 \mathrm{E}+07$ & 6 & 35500 & 54800 \\
\hline & $\mathrm{PO}_{4}$ & 32500 & $1.40 \mathrm{E}+07$ & $1.00 \mathrm{E}+06$ & 6 & 20400 & 44500 \\
\hline & $\mathrm{NO}_{2}$ & 9150 & $1.20 \mathrm{E}+07$ & 999000 & 5 & 6580 & 11700 \\
\hline \multirow[t]{2}{*}{ Carbon $(\mu \mathrm{g} / \mathrm{g})$} & TOC & 955 & $3.39 \mathrm{E}+08$ & $2.42 \mathrm{E}+07$ & 5 & 436 & 1470 \\
\hline & $\mathrm{CO}_{3}$ & 4350 & 488000 & 40600 & 6 & 1900 & 6790 \\
\hline \multirow[t]{6}{*}{$\mathrm{RA}(\mu \mathrm{Ci} / \mathrm{g})$} & Total $\beta$ & 8.66 & 56.7 & 4.05 & 6 & 3.73 & 13.6 \\
\hline & Cs -137 & 7.24 & 27.7 & 1.98 & 6 & 3.80 & 10.7 \\
\hline & C-14 & 0.000342 & $4.58 \mathrm{E}-08$ & $4.16 \mathrm{E}-09$ & 5 & 0.000177 & 0.000508 \\
\hline & Sr-90 & 0.119 & 0.0217 & 0.00160 & 6 & 0.0225 & 0.215 \\
\hline & Te-99 & 0.00715 & 0.0000945 & $6.75 \mathrm{E}-06$ & 6 & 0.000794 & 0.01135 \\
\hline & H-3 & 0.00236 & 8.84 E-08 & 7.37 E-09 & 5 & 0.00214 & 0.00258 \\
\hline AAS $(\mu \mathrm{g} / \mathrm{g})$ & $\mathrm{Hg}$ & 0.0585 & 0.00310 & 0.000400 & 3 & 0 & 0.1126 \\
\hline \multirow[t]{14}{*}{ ICP $(\mu \mathrm{g} / \mathrm{g})$} & $\mathrm{Al}$ & 3510 & $1.99 \mathrm{E}+06$ & 142000 & 6 & 2590 & 4430 \\
\hline & B & 330 & 18900 & 1350 & 6 & 240 & 420 \\
\hline & $\mathrm{Ca}$ & 127 & 13800 & 983 & 6 & 50 & 204 \\
\hline & $\mathrm{Cr}$ & 498 & 166000 & 11800 & 6 & 232 & 164 \\
\hline & $\mathrm{Fe}$ & 43 & 752 & 84 & 5 & 20 & 67 \\
\hline & $\mathrm{Li}$ & 21 & 530 & 76 & 3 & 0 & 49 \\
\hline & $\mathrm{Mg}$ & 381 & 420000 & 30000 & 6 & 0 & 805 \\
\hline & $\mathrm{Hg}$ & 36 & 500 & 38 & 6 & 20 & 51 \\
\hline & $\mathrm{Na}$ & 80600 & $7.75 \mathrm{E}+08$ & $5.53 E+07$ & 6 & 62400 & 98800 \\
\hline & $\mathrm{Sr}$ & 5.8 & 34.8 & 5.00 & 3 & 0 & 12.9 \\
\hline & $s$ & 641 & 346000 & 24700 & 6 & 256 & 1020 \\
\hline & $\mathrm{Tl}$ & 649 & 205000 & 22700 & 5 & 261 & 1040 \\
\hline & $\mathrm{Ti}$ & 23 & 590 & 118 & 2 & 0 & 69 \\
\hline & $\mathrm{Zn}$ & 23 & 253 & 18.0 & 6 & 13 & 33 \\
\hline
\end{tabular}

AAS = Atomic Absorptien-Speetroscopy- Analysis

IC $=$ Ion Chromatography

ICP = Inductively Coupled Plasma Analysis

RA = Radiological Analysis

UA $=$ Untreated Analysis. 
Table 7-6. Water Digestion, Confidence Limits as Percent of the Mean.

\begin{tabular}{|c|c|c|c|}
\hline \multicolumn{2}{|c|}{ Method and enalyte } & \multirow{2}{*}{$\frac{\overline{9}}{11.4}$} & \multirow{2}{*}{$\frac{\mathrm{CL}(\%)}{4.00}$} \\
\hline UA & pH & & \\
\hline \multirow[t]{5}{*}{$\overline{I C}(\mu \mathrm{g} / \mathrm{g})$} & $\mathbf{F}$ & 7050 & 26.0 \\
\hline & C & 1020 & 98.0 \\
\hline & $\mathrm{NO}_{3}$ & 45100 & 21.0 \\
\hline & $\mathrm{PO}_{4}$ & 32500 & 37.0 \\
\hline & $\mathrm{NO}_{2}$ & 9200 & 28.0 \\
\hline \multirow[t]{2}{*}{ Carbon $(\mu \mathrm{g} / \mathrm{g})$} & TOC & 955 & 54.0 \\
\hline & $\mathrm{CO}_{3}$ & 4350 & 56.0 \\
\hline \multirow[t]{6}{*}{$\mathrm{RA}(\mu \mathrm{Ci} / \mathrm{g})$} & Total B & 8.66 & 57.0 \\
\hline & Cs 137 & 7.24 & 48.0 \\
\hline & C 14 & 0.000342 & 48.0 \\
\hline & $\mathrm{Sr} 90$ & 0.119 & 81.0 \\
\hline & Tc 99 & 0.00715 & 89.0 \\
\hline & H3 & 0.00236 & 9.00 \\
\hline AAS $(\mu \mathrm{g} / \mathrm{g})$ & $\mathbf{H g}$ & 0.0585 & 115 \\
\hline \multirow[t]{14}{*}{ ICP $(\mu \mathrm{g} / \mathrm{g})$} & $\mathrm{Al}$ & 3510 & 26.0 \\
\hline & B & 330 & 27.0 \\
\hline & $\mathrm{Ca}$ & 127 & 60.0 \\
\hline & $\mathrm{Cr}$ & 498 & 53.0 \\
\hline & $\mathrm{Fe}$ & 43 & 54.0 \\
\hline & $\mathrm{Li}$ & 21 & 133 \\
\hline & $\mathbf{M g}$ & 381 & 111 \\
\hline & $\mathrm{Hg}$ & 36 & 43.0 \\
\hline & $\mathrm{Na}$ & 80600 & 23.0 \\
\hline & $\mathrm{Sr}$ & 5.8 & 121 \\
\hline & $\mathbf{S}$ & 641 & 60.0 \\
\hline & $\mathrm{Tl}$ & 649 & 60.0 \\
\hline & $\mathrm{Ti}$ & 23 & 205 \\
\hline & $Z_{n}$ & 23 & 45.0 \\
\hline
\end{tabular}

AAS = Atomic Absorption Spectroscopy Analysis

$C L=t * \hat{\sigma}(\bar{y}) * 100 / \bar{y}$

IC = Ion Chromatography

ICP = Inductively Coupled Plasma Analysis

RA = Radiological Analysis

$\mathrm{UA}=$ Untreated Analysis. 


\subsection{ANALYTES}

Each of the three sets of concentration estimates is based upon a different sample preparation method: acid digestion, $\mathrm{KOH}$ fusion dissolution, and water digestion. Table 7-7 lists the chemical analysis methods used with each preparation and the analytes in each category.

Table 7-7. Analytes Measured in Tank U-110.

\begin{tabular}{|c|c|c|}
\hline Sample preparation & Method & Analytes \\
\hline \multirow[t]{2}{*}{ Acid digestion } & AAS & $\mathrm{As}, \mathrm{Hg}, \mathrm{Se}$ \\
\hline & ICP & $\begin{array}{l}\mathrm{Al}, \mathrm{As}, \mathrm{B}, \mathrm{Ba}, \mathrm{Be}, \mathrm{Bi}, \mathrm{Ca}, \mathrm{Cr} \\
\mathrm{Cu}, \mathrm{Fe}, \mathrm{Hg}, \mathrm{Mg}, \mathrm{Mn}, \mathrm{Mo}, \mathrm{Na}, \\
\mathrm{Ni}, \mathrm{P}, \mathrm{Pb}, \mathrm{S}, \mathrm{Se}, \mathrm{Si}, \mathrm{Sn}, \mathrm{Sr}, \mathrm{Th} \text {, } \\
\mathrm{Ti}, \mathrm{Tl}, \mathrm{U}, \mathrm{V}, \mathrm{Zn}, \mathrm{Zr}\end{array}$ \\
\hline \multirow[t]{2}{*}{ KOH Fusion dissolution } & $\mathbf{R A}$ & $\begin{array}{l}\text { Aml-241, Cs-137, Pu-239/240, } \\
\text { Sr-90, U, Total } \alpha \text {, Total } \beta\end{array}$ \\
\hline & ICP & $\begin{array}{l}\mathrm{Al}, \mathrm{B}, \mathrm{Bi}, \mathrm{Ca}, \mathrm{Cr}, \mathrm{Fe}, \mathrm{Mg}, \mathrm{Mn} \text {, } \\
\mathrm{Na}, \mathrm{Ni}, \mathrm{Pb}, \mathrm{S}, \mathrm{Se}, \mathrm{Si}, \mathrm{Sr}, \mathrm{Zn}, \\
\mathrm{Zr}\end{array}$ \\
\hline \multirow[t]{6}{*}{ Water digestion } & UA & $\mathrm{pH}$ \\
\hline & IC & $\mathrm{Cl}, \mathrm{F}, \mathrm{NO}_{2}, \mathrm{NO}_{3}, \mathrm{PO}_{4}$ \\
\hline & Carbon & $\mathrm{TOC}, \mathrm{CO}_{3}$ \\
\hline & AAS & $\mathrm{Hg}$ \\
\hline & ICP & $\begin{array}{l}\mathrm{Al}, \mathrm{B}, \mathrm{Ca}, \mathrm{Cr}, \mathrm{Fe}, \mathrm{Hg}, \mathrm{Li}, \mathrm{Mg} \\
\mathrm{Na}, \mathrm{S}, \mathrm{Sr}, \mathrm{Ti}, \mathrm{Tl}, \mathrm{Zn}\end{array}$ \\
\hline & RA & $\begin{array}{l}\text { TB, Cs-137, C-14, Sr-90, } \\
\text { Tc-99, Tritium }\end{array}$ \\
\hline
\end{tabular}

AAS $=$ Atomic Absorption Spectroscopy Analysis

$\mathrm{IC}=$ Ion Chromatography

ICP = Inductively Coupled Plasma Analysis

RA $=$ Radiological Analysis

$\mathrm{UA}=$ Untreated Analysis.

\subsection{CONCLUSION}

The summary statistics for the concentration of specific analytes in tank $U-110$ are listed in Tables 7-1, 7-3, and 7-5. 


\subsection{REMAINING STATISTICAL TESTS FOR TANK U-110}

Analytical concentration data from the seven core samples from tank U-110 were used to estimate the concentration of the various analytes found in the waste. Each core sample consisted of four segments. The recovered core segments were homogenized and a composite sample, representing each core, was formed by combining individual samples from each homogenized segment.

The core composite sample was also homogenized. Two aliquots were drawn from each core composite sample and prepared for chemical analysis. For each analyte, the concentration estimates were computed based upon these pairs of data.

To estimate the mean composition of the SST based upon the chemical analysis of core composite samples two assumptions must be valid.

- The 222-S Laboratory can homogenize and sample individual segments.

- The 222-S Laboratory can combine and rehomogenize samples from the segments to form the core composite sample.

If these two assumptions are valid, the composite sample will represent the entire core. To check the validity of these assumptions, two statistically designed tests were performed in the 222-S Laboratory. Based upon the results from these two tests, both assumptions are valid (Jensen and Remund 1993).

The results of these two tests are summarized in the following paragraphs. In addition, the results of a third test performed in the 222-S Laboratory are also summarized. The third test, the holding time study, was designed to determine whether or not the core sample analytical concentrations changed as the sample aged.

\subsection{SUMMARY OF THE STATISTICAL EVALUA'TION OF HOMOGENIZATION TEST DATA}

A core sample of waste consists of disjoint segments. A segment is $48 \mathrm{~cm}$ (19 in.) long and approximately $2.5 \mathrm{~cm}$ ( 1 in.) in diameter. In the laboratory, a segment is homogenized (mixed), aliquots are formed from a sample drawn from the homogenized segment, and the aliquots are prepared for chemical analysis. The sample material in a segment is homogenized so that it can be-characterized-by-analyzing a minimum number of: aliquots.

Homogenization of samples is a critical step in preparing sample material. Consequently, to evaluate the ability of the laboratory to homogenize samples, the homogenization test was performed. 
The homogenization test was performed on sample material from three different segments from tank U-110. Data were available for seven analytes (aluminum, cesium-137, iron, magnesium, silicon, sodium, and strontium). The results of the statistical analysis of the data are that, for these seven analytes, the 222-S Laboratory can adequately homogenize sample material similar to that found in SST 241-U-110.

\subsection{SUMMARY OF THE COMPARISON BETWEEN A SIMULATED CORE COMPOSITE AND THE CORE COMFOSITE SAMPLE}

A simulated core composite was formed by combining data obtained from the individual segments within a core. The results from this simulated core composite were statistically compared with the corresponding data from the core composite sample formed in the 222-S Laboratory.

The general conclusion from this study is that the core composite sample composition agrees with the composition predicted by using the individual segments, which means that the 222-S Laboratory can construct a core composite sample from individual segments. This result also means that the SST concentration data obtained from a core composite sample agree with the corresponding values obtained from the individual segments.

There is a lack of agreement between certain pairs of segment data. The influence of this lack of agreement on the conclusions above was checked by deleting outlying pairs of data and reevaluating the statistical comparisons. The general conclusions did not change.

\subsection{SUMMARY OF THE STATISTICAL EVALUATION OF THE HOLDING TIME TEST DATA}

The holding time study was designed to determine whether or not the concentration of an analyte changed with time as the samples aged in the 222-S Laboratory. This test is referred to as the holding time study. The holding time is the length of time a "sample" is held in the 222-S Laboratory before the chemical analysis is initiated. The holding time test was performed on samples obtained from homogenized material from segments $1,2,3$, and 4 of core 14 from tank U-110.

Segment 1 was noticeably different than the other segments in the analyte concentrations. For this reason, statistical analyses were performed for segment 1 alone and segments 2,3 ; and -4 were combined.

For segments 2,3 , and 4 , there were significant differences between holding times the for mercury, nitrite, TOC, and chloride. The differences between holding times for mercury and TOC depend on the segment (e.g., one segment may show a concentration increase over time while another segment may show a decrease). There were no significant differences 
between holding times for $\mathrm{pH}$, hydrogen concentration, percent water, nitrate, and phosphate for segments 2,3 , and 4 .

For segment 1, there were significant differences between holding times for percent water and hydrogen concentration. There were no significant differences between holding times for $\mathrm{pH}$ and mercury. There was insufficient data for a statistical analysis on segment 1 for nitrate, nitrite, TOC, phosphate, and sulfate. The results, for segment 1 alone, should be viewed with caution because of the small number of observations.

\subsection{SUMMARY OF THE VARIANCE COMPONENTS}

The Statistical Characterization Report for Single-Shell Tank 241-U-110 (Jensen and Remund 1993) also contains a section listing explicit estimates of the spatial and analytical variance components for the analytes found in tank U-110. These variance components are determined from the analysis of variance model used to estimate the concentration of the analytes in the tank. In addition, for each of the variance components, confidence intervals, relative standard deviations, and relative percent variance values are also given. These statistics are used to judge the magnitude of the variance components and the degree of heterogeneity of the waste.

The general conclusion is that there is large variability in the data (in the waste). The analytical relative standard deviation varies between 6 and 150 percent. The spatial relative standard deviation varies between 0 and 89 percent. The analytical variance, as a percent of the total, varies between 1 and 100 percent. The spatial variance, as a percent of the total, varies between 0 and 99 percent. There is no apparent pattern in the magnitudes of the variances. 


\subsection{TWRS PROGRAM ELEMENT CHARACTERIZATION SYNOPSIS}

This section provides selected results obtained from core sampling for some of the most pertinent analytes for the various TWRS program elements, including Hanford Waste: Vitrification Plant (HWVP), Retrieval, Pretreatment, and Waste Tank Safety. Analytes of interest will be reported on a level of resolution commensurate with the available data and program direction.

\subsection{BULK AVERAGE VERSUS LOCATION SPECIFIC RESULTS}

Depending on the program element, characterization results can be reported as bulk average values or location specific values. Bulk average results are useful in determining the overall inventory of a particular analyte in a tank. Generally, the bulk averages are expressed as an overall average with a 95 percent lower and upper confidence interval from that average. That is to say, there is 95 percent confidence that the true bulk average concentration of any given analyte in the tank lies within the range of the upper and lower 95 percent confidence intervals. Bulk average results are important to waste processing programs such as Pretreatment and HWVP as well as to the Safety program.

Location-specific results are important in determining where possible high concentrations of a particular analyte may exist in the tank. This information is generally presented as an overall average with a range from the lowest available data point to the highest available data point. Location specific results are important to the Retrieval program as well as the Safety program.

\subsection{SAFETY PROGRAM CHARACTERIZATION DATA SUMMARY}

By law, the U.S. Department of Energy was to determine which tanks have the potential to release high-level waste because of uncontrolled increases in temperature or pressure. To date, several tanks have been identified as being candidates of this safety issue and hence are under operating restrictions, but tank U-110 is not currently under operating constrictions (Reep 1992). In this section, the relevant data concerning the safety of the tank will be presented. These data may be compared to the established safety criteria to show that tank U-110 does not satisfy any of the current conditions of operational restrictions.

Several safety categories and subsequent safety criteria involved in determining whether a tank is safe or unsafe are discussed below.

The first safety category is the gas-generating tanks. Several Hanford Site waste tanks have exhibited the generation and periodic release of gas, especially hydrogen. The primary criteria of ascertaining a gas-generating tank is whether it displays slurry growth. Other factors include surface level fluctuation, presence of hydrogen in the dome space, fluctuation 
in the dome space pressure, waste type, and organic content. Currently, tank U-110 does not manifest any of these phenomena.

Another important safety criteria is the presence of ferrocyanide in the tank.

Ferrocyanide is a potential explosive under the proper conditions. The criteria used to detect a ferrocyanide tank is the presence of 1,000 gram moles of ferrocyanide or more. As can be seen in Table 8-1, the analytical results showed that ferrocyanide is below the detection limits and hence also well below the ferrocyanide safety criteria. This result is consistently true of all of the core samples. It is important to note that these results were obtained using the micro distillation method. This method yields inaccurate results when the cyanide is low $(\leq 500 \mathrm{ppm})$ and also has a high bias.

Table 8-1. Tank U-110 Safety Considerations. *

\begin{tabular}{|c|c|c|}
\hline Safety category & Safety criteria & Value for tank U-110 \\
\hline Ferrocyanide & $\begin{array}{l}1,000 \text { gram mole } \\
\text { ferrocyanide }\end{array}$ & No cyanide detected in the tank \\
\hline High heat & $40,000 \mathrm{Btu} /$ hour & $\begin{array}{ll}\text { Lower: } & 6000 \mathrm{Btu} / \text { hour } \\
\text { Mean: } & 8800 \mathrm{Btu} / \text { hour } \\
\text { Upper: } & 11,600 \mathrm{Btu} / \text { hour }\end{array}$ \\
\hline Organic & $\begin{array}{l}3 \text { Dry weight percent total } \\
\text { organic carbon }\end{array}$ & $\begin{array}{ll}\text { Lower: } & 0.08 \mathrm{DRY} \text { wt percent } \\
\text { Mean: } & 0.17 \mathrm{DRY} \text { wt percent } \\
\text { Upper: } & 0.27 \mathrm{DRY} \text { wt percent }\end{array}$ \\
\hline Plutonium & $\begin{array}{c}50 \mathrm{~kg} \text { - Total inventory } \\
\text { plutonium }\end{array}$ & $\begin{array}{l}\text { Lower: } 2.8 \mathrm{~kg} \\
\text { Mean: } 4.0 \mathrm{~kg} \\
\text { Upper: } 5.2 \mathrm{~kg}\end{array}$ \\
\hline
\end{tabular}

*Lindsay 1986, RHO 1988, Boyles 1992, Reep 1992).

The third safety concern is whether the tank is a high-heat-generating tank. The criteria for ascertaining a high-heat tank is that it generates $40,000 \mathrm{Btu} / \mathrm{h}$ or more of heat. Heat is approximated by the amount of strontium- 90 and cesium-137 found in the tank. Although there are other heat generating elements in the tank, strontium and cesium produce the majority of the heat. When calculating the heat load of the tank, it is best to use the "worst case" approximations of the concentrations of strontium and cesium. In Section 7.4, the statistical concentration estimates of the analytes found in the tank are given. The results are presented as the mean of the comcentration of the analyte in the tank as well as the upper and lower bounds of the concentration of the analyte. These bounds are given for a 95 percent confidence interval. Hence, when calculating the heat load from strontium and cesium, the upper bound should be considered. By calculating the upper limit heat load within a 95 percent confidence interval, the worst-case scenario (within reason) may be analyzed. As shown in Table 8-1, the upper 95 percent heat load for tank U-110 is $12,000 \mathrm{Btu} / \mathrm{h}$, below the high-heat limit of $40,000 \mathrm{Btu} / \mathrm{h}$. The average heat load and lower 95 percent heat load are also shown. 
The fourth safety concern is the presence of organic material in the tank. The presence of $3 \mathrm{dry} w \mathrm{w} \%$ or more TOC gives indication of an organic tank. The upper limit TOC within a 95 percent confidence interval as shown in Table $8-1$ is 0.27 dry wt\%, which is also well below the safety criteria. It is important to consider that it is still possible to have sample points above the 95 percent confidence intervals; this is the case with core 15 , segment 2, for the TOC measurement. This segment shows a TOC value of 0.66 wet wt\% (dry TOC of $1.1 \mathrm{wt} \%$ ). This TOC value is an outlier and gives a worst-case depiction that is still within the established "safe" criteria.

Another issue of concern is the total amount of plutonium in the tank. An excess of $50 \mathrm{~kg}$ of plutonium in the tank would raise the issue of potential criticality in the tank. The maximum inventory of plutonium in the tank as shown in Table $8-1$ is $5.2 \mathrm{~kg}$, which is below the criticality criteria. Again, this calculation was based on the worst-case 95 percent upper confidence interval. Again, with the plutonium estimates, there are values given that are above the 95 percent confidence interval. In core composite 12 , plutonium is recorded to be $0.35 \mu \mathrm{Ci} / \mathrm{g}$, which would give a total inventory of $5.6 \mathrm{~kg}$, well within the safe range. It should be noted that because the waste in the tank is heterogeneous and because there was a poor recovery, the plutonium determination is not bounding.

\subsection{RETRIEVAL PROGRAM CHARACTERIZATION DATA SUMMARY}

A major objective of the Characterization progrann is to measure the physical properties of the waste to support waste retrieval technology development. The physical characteristics of tank waste are required to develop design criteria for waste retrieval equipment, provide a basis for simulated waste development, and to provide a basis for validation of equipment testing using design criteria and simulated waste. The analytical methods to determine the physical properties of the waste as it actually exists in the tank require a substantial amount (50 to $100 \mathrm{~g}$ ) of unhomogenized sample. In the case of tank U-110, the limited amount of sample recovered constrains the number of analyses that can be performed.

Selected rheological and physical properties are presented in Table 8-2. Note that the Retrieval results are location specific and hence the range of data points is given.

Table 8-2. Retrieval Program.

\begin{tabular}{|l|c|c|}
\hline \multicolumn{1}{|c|}{ Analyte } & Bulk average & Range of data points \\
\hline Bulk density $(\mathrm{g} / \mathrm{cc})$ & 1.5 & $1.0-1.9$ \\
\hline Viscosity $(\mathrm{cP})$ & Not analyzed & Not analyzed \\
\hline Mean particle size $(\mu \mathrm{m})$ & & \\
- Number distribution & Not calculated & $1.0-2.0$ \\
- Volume distribution & Not calculated & $2.0-12.0$ \\
\hline Settling time (hours) & Not analyzed & Not analyzed \\
\hline
\end{tabular}




\subsection{PRETREATMENT PROGRAM CHARACTERIZATION DATA SUMMARY}

The majority of the programmatic decisions pertaining to the design of pretreatment and final disposal systems shall be based on the average characteristics of the tank waste. Therefore, the majority of the laboratory analyses were conducted on representative core composites. The constituent inventories were calculated by either treating the core samples: as random samples and averaging the results, or by using a spatial model. The calculated inventories will include an estimated total quantity of each selected analyte and its corresponding confidence interval based on analytical and sampling variability.

Chemical analytes of interest are presented in Table 8-3. This table indicates selected analytes of known interest. Note that the last column of the table offers the bulk inventory of the analytes in the tank based on the calculated bulk average concentration and the total waste volume. Note also that the range of Pretreatment results are given as a confidence interval of bulk averages instead of a range of data points.

Table 8-3. Pretreatment Program.

\begin{tabular}{|l|c|c|c|}
\hline \multicolumn{1}{|c|}{ Analyte } & Bulk average & $\begin{array}{c}\text { Confidence interval of } \\
\text { bulk average fron - } \\
95 \% \text { to }+95 \%\end{array}$ & $\begin{array}{c}\text { Bulk tank } \\
\text { inventory }\end{array}$ \\
\hline Minor ICP analytes $(\mu \mathrm{Ci} / \mathrm{g})$ & 3,430 & $0-7,400$ & $3,410 \mathrm{~kg}$ \\
Boron & 610 & $320-900$ & $610 \mathrm{~kg}$ \\
Chromium & 2,540 & $470-4,610$ & $2,530 \mathrm{~kg}$ \\
Magnesium & 22,200 & $0-53,500$ & $22,150 \mathrm{~kg}$ \\
Silicon & 170 & $130-210$ & $170 \mathrm{~kg}$ \\
Zirconium & Not analyzed & Not analyzed & Not applicable \\
\hline Percent insoluble solids & & &
\end{tabular}

\subsection{HWVP CHARACTERIZATION DATA SUMMARY}

The HWVP Program has characterization needs in addition to those described for core sampling. Transforming waste into glass is primarily for the disposal of highlevel/transuranic solids in a geologic repository. The vitrification process will be performed after the solids have been pretreated, thus, the core sample information will provide preliminary bounding design conditions for the glass plant. Further characterization for technology development and regulatory compliance will be necessary on the pretreated waste that will be fed to the vitrification plant. The analytical requirements for the HWVP program are identified in the Hanford Waste Vitrification Plant Feed Characterization Requirements Revision 4 (Wagner 1992). 
The analytical program for HWVP not only entails determining whether a waste type is suitable for disposal as glass, but also includes determining the physical and chemical characteristics of the glass for process control purposes and to ensure regulatory compliance. Sampling and analysis plans will be developed on an individual basis for each tank or process batch. The characterization needs for these efforts include analyses for metals, water-soluble anions, radionuclides, semi-volatile organics, and rheological and physical testing for both the HWVP feed and vitrified product.

Tank U-110 is not scheduled as an early feed to HWVP.

Two selected groups of analytes are presented in this summary. One provides a set of analytes of interest to the vitrification process stream and is found in Table 8-4. The other: are analytes of interest to the regulatory permitting of such a facility and are given in Table 8-5. As with Pretreatment, these analytes are presents as confidence intervals of the bulk averages.

Table 8-4. HWVP Process Stream Analytes of Concern.

\begin{tabular}{|l|c|c|c|}
\hline \multirow{2}{*}{\begin{tabular}{c|c|} 
Analyte \\
Bulk average
\end{tabular}} & $\begin{array}{c}\text { Confidence interval } \\
\text { of bulk average } \\
\text { from }-95 \% \text { to }+95 \%\end{array}$ & Bulk tank inventory \\
\hline Phosphate $(\mu \mathrm{g} / \mathrm{g})$ & 32,500 & $20,400-44,500$ & $32,320 \mathrm{~kg}$ \\
\hline Fluoride $(\mu \mathrm{g} / \mathrm{g})$ & 7,050 & $5,200-8,900$ & $7,020 \mathrm{~kg}$ \\
\hline Chloride $(\mu \mathrm{g} / \mathrm{g})$ & 1,020 & $16-2,020$ & $1,020 \mathrm{~kg}$ \\
\hline Cs-137 $(\mu \mathrm{Ci} / \mathrm{g})$ & 28.2 & $15.6-40.8$ & $0.32 \mathrm{~kg}$ \\
\hline $\mathrm{Sr}-90(\mu \mathrm{Ci} / \mathrm{g})$ & 367 & $251-482$ & $2.63 \mathrm{~kg}$ \\
\hline
\end{tabular}

Table 8-5. HWVP Regulatory Operation Analytes of Concern.

\begin{tabular}{|l|c|c|c|}
\hline \multicolumn{1}{|c|}{ Analyte } & Bulk average & $\begin{array}{c}\text { Confidence interval } \\
\text { of bulk average from } \\
-95 \%+0+95 \%\end{array}$ & $\begin{array}{l}\text { Bulk tank } \\
\text { inventory }\end{array}$ \\
\hline Mercury $(\mu \mathrm{g} / \mathrm{g})$ & 3.0 & $0-8.4$ & $2.95 \mathrm{~kg}$ \\
\hline Carbon-14 $(\mu \mathrm{Ci} / \mathrm{g})$ & $3.4 \mathrm{E}-04$ & $1.8 \mathrm{E}-04-5.1 \mathrm{E}-04$ & $7.63 \mathrm{E}-05 \mathrm{~kg}$ \\
\hline Iodine-129 $(\mu \mathrm{Ci} / \mathrm{g})$ & - Not-detected & -Not-detected & Not detected \\
\hline Technetium-99 $(\mu \mathrm{Ci} / \mathrm{g})$ & $7.1 \mathrm{E}-03$ & $7.9 \mathrm{E}-04-1.4 \mathrm{E}-02$ & $0.42 \mathrm{~kg}$ \\
\hline
\end{tabular}


WHC-SD-WM-ER-551 Rev, 0

This page intentionally left blank. 


\subsection{CONCLUSIONS}

The objective of this report is to present the results of the investigation of the nature of the waste found in tank U-110. Through examination of the history of tank U-110, as well as a study of current tank data, the physical, thermal, and chemical properties of the waste in the tank have been identified.

Tank U-110 was constructed in 1943 and is among the oldest of the tanks in the Hanford Site tank farms. Historically, it was used to support the waste storage needs of both the early $\mathrm{BiPO}_{4}$ separation process and later to store waste from the REDOX process. Specifically, tank U-110 received $1 \mathrm{C}$ waste from the $\mathrm{BiPO}_{4}$ process and $\mathrm{R}$ waste and CWF waste from the REDOX process. Because all of these waste types had an exceptionally high concentration of aluminum, aluminum is expected to be found in the tank in abundance. Other analytes expected to be found in abundance from these waste types are bismuth, phosphate, and fluoride. Because sodium hydroxide was used to increase the $\mathrm{pH}$ of the tank, high concentrations of sodium, as well as high hydroxide levels, were also expected.

Both the tank sampling and the sample extrusion events revealed much information about the physical description and physical properties of the waste. While sampling the tank, the top 10 to $38 \mathrm{~cm}$ (4 to $15 \mathrm{in}$.) of the waste were very hard. The remaining $145 \mathrm{~cm}$ ( 57 in.) of the waste were softer and easier to push the sampler through. The top crusty layer led to an overall poor waste recovery in the sampling effort of tank U-110. The existence of a harder layer at the top of the waste was confirmed during the extrusion of the samples. In every core where the top segment was retrieved, the waste was described as being white in color and often noncohesive. The second, third, and fourth segments were described as light to dark brown in color. This waste was softer and often more cohesive than the top white layer. The bulk or wet density of the waste was calculated to be approximately $1.5 \mathrm{~g} / \mathrm{cc}$ and the dry particle density is approximately $1.9 \mathrm{~g} / \mathrm{cc}$.

A thermal analysis was performed on the tank core composites. The thermal analysis consisted of a DSC analysis and a TGA analysis. The purpose of the DSC was to evaluate the reactive nature of the tank. No exothermic reactions were observed in the tank waste, which indicates that the tank is safe from the possibility of a dangerous runaway reaction. It was observed that there were consistently two endotherrnic events occurring during the thermal analyses. The first event occurred at about $100^{\circ} \mathrm{C}$ and was determined to be the evaporation of water. The second event occurred at about 300 to $330^{\circ} \mathrm{C}$ and was determined to be the decomposition of aluminum hydroxide $\left(\mathrm{Al}(\mathrm{OH})_{3}\right)$ to aluminum oxide and water vapor,- It-was-ebserved-that-only-the-core-eomposites-that contained the top white material had the aluminum hydroxide peak in the DSC. Core composite 8, which contained only white sample waste, was determined to contain more than 75 percent aluminum hydroxide. Similarly, the more brown material in the composite, the higher the water peak in the DSC; this leads to the conclusion that the top white layer of the tank is composed primarily of aluminum hydroxide and is low in water, whereas the brown sludge in the bottom portion of the tank is high in water. 
A particle size distribution was performed on the segment samples from which the number and volume particle distributions were obtained. The probability number distributions from these analyses indicated that the majority ( 90 percent) of the identifiable particles fit within the narrow band of 0.4 to 1.5 microns. However, the volume distribution indicated that over 50 percent of the actual mass of the waste was represented by particles over 5 microns. The dispersant used for these analyses was either water or an ethanolglycerine mixture. For a true particle size distribution, the mother liquor of the tank should be used. The water dispersant analyses are still useful because retrieval operations are likely to use water.

The chemical analyses performed on the tank U- 110 waste were very useful in identifying what remaining analytes are found in the waste. It was seen that, in agreement to historical records, aluminum is found in abundance throughout the waste. It was already shown that the top layer of the waste is primarily aluminum hydroxide. The remainder of the waste probably contains aluminum in the form of aluminum oxide, aluminum hydroxide in the form of boehmite (AlOOH), and even some in soluble forms, such as sodium aluminate. Both bismuth and phosphate exist in high quantities in the bottom portions of the waste probably in the form of bismuth phosphate. Large amounts of sodium exist in all of the segments except for the top segment (white layer). Anions such as fluoride, nitrate, and nitrite exist throughout these sludge segments as well. Most of these anions probably occur in the form of sodium salts. The remaining sodium (that is not ionically bonded to the anions) likely occurs as sodium hydroxide.

One shortcoming of the chemical data was that an ICP analysis was not performed on fusion dissolution samples from the segments. Some analytes had consistently higher ICP concentrations in the fusion dissolution analysis than the acid digestion analysis. In particular, these were silicon, and the major metals: aluminum, calcium, magnesium, and sodium. In future characterization efforts, if it is desired to know the concentration of silicon or the major metals in the segment data, fusion ICP should be performed on the segments.

By law, it is necessary to determine those tanks that have the potential to release highlevel waste due to an uncontrolled increase in temperature and pressure. Specific criteria have been established to determine which tanks need to be kept under operating constrictions. These criteria have been compared to the current data for tank U-110 in Table 8-1. According to this comparison, tank U-110 is well below the established safety criteria that define a gas-generating tank, a ferrocyanide tank, a high-heat tank, an organic tank, or a potential criticality tank.

In the statistical analysis of tank U-110, estimates of the mean concentration as well as the confidence intervals on the mean concentrations were calculated (see Tables 7-1, 7-3, and 7-5). In estimating these mean concentrations and confidence intervals, it was assumed that the 222-S Laboratory can effectively homogenize and sample individual segments. It was also assumed that the laboratory could combine and rehomogenize samples from the segments to form the core composite sample. Based on the results of statistical analyses on tank U-110 data, these two assumptions are both valid. 


\subsection{REFERENCES}

Anderson, J. D., 1992, A History of the 200 Area Tank Farms, WHC-MR-0132, Westinghouse Hanford Company, Richland, Washington.

Boyles, V. C., 1992, Operating Specifications for Single-Shell Waste Storage Tanks, OSD-T-151-00013 Rev. D-1, Westinghouse Hanford Company, Richland, Washington.

Brown, T. M., and L. Jensen, 1993, Tank Characterization Report for Single-Shell Tank 241-U-110, WHC-EP-0643, Westinghouse Hanford Company, Richland, Washington.

Burton, G. Jr., 1975, "Status of Tank 241-U-110," Internal Memo, U.S. Energy Research and Development Administration, Richland, Washington.

Dean, J. A., 1985, Lange's Handbook Of Chemistry, Thirteenth Edition, McGraw-Hill Inc., New York, New York.

Hanlon, B. M., 1991, Tank Farm Surveillance and Waste Status Report for April 1991, WHC-EP-0182-37, Westinghouse Hanford Company, Richland, Washington.

Hill, J. G., W. I. Winters, B. C. Simpson (Westinghouse Hanford Company), J. W. Buck, P. J. Chamberlain, and V. L. Hunter (Pacific Northwest National Laboratory), 1991, Waste Characterization Plan for the Hanford Site Single-Shell Tanks, WHC-EP-0210, Revs. 1 and 2, Westinghouse Hanford Company, Richland, Washington.

Jensen, L., and A. M. Liebetrau, 1988, Statistical Techniques for Characterizing Single-Shell Tank Waste, WHC-SA-0348-FP, Rev. 1, Westinghouse Hanford Company, Richland, Washington.

Jensen, L., and K. M. Remund, 1993, Statistical Characterization Report for Single-Shell Tank 241-U-110, WHC-SD-WM-TI-560, Rev. 0, Westinghouse Hanford Company, Richland, Washington.

Lindsey, D. W., 1986, Operating Specifications for Single-Shell Waste Storage Tanks, OSD-T-151-00013, Rockwell Hanford Operations, Richland, Washington.

Perry, R. H., and D.-W.-Green, 1984,-Perry's Chemical Engineers' Handbook, Sixth Edition, McGraw-Hill Inc., New York, New York.

RHO, 1988, Criticality Prevention Specifications for Waste Storage Tanks and Associated Equipment, CPS-T-149-00010, Rockwell Hanford Operations, Richland, Washington. 
Reep, I. E., 1992, Status Report on Resolution of Waste Tank Safety Issues at the Hanford Site, WHC-EP-0600, Westinghouse Hanford Company, Richland, Washington.

Schneider, K. J., 1951, Flow Sheet and Flow Diagrams of Precipitation Separations Process, HW-23043, General Electric Company, Richland, Washington.

Searle, S. R., 1971, Linear Models, John Wiley \& Sons, Inc., New York, New York.

Snedecor, G. W., and W. G. Cochran, 1980, Statistical Methods, Seventh Edition, Iowa State University Press, Ames, Iowa.

WHC, 1991, Sample Management and Administration, WHC-CM-5-3, Westinghouse Hanford Company, Richland, Washington.

\subsection{DATA PACKAGES}

\subsubsection{Core Composites}

WHC, 1991, Laboratory Report 222-S/RCRA Analytical Laboratories, Single Shell Tank Waste Characterization, Tank 241-U-110, Core 5, Core 5 Composite Rev. 2, Westinghouse Hanford Company, Richland, Washington.

WHC, 1991, Laboratory Report 222-S/RCRA Analytical Laboratories, Single Shell Tank Waste Characterization, Tank 241-U-110, Core 6, Core 6 Composite Rev. 2, Westinghouse Hanford Company, Richland, Washington.

WHC, 1991, Laboratory Report 222-S/RCRA Analytical Laboratories, Single Shell Tank Waste Characterization, Tank 241-U-110, Core 7, Core 7 Composite Rev. 2, Westinghouse Hanford Company, Richland, Washington.

WHC, 1991, Laboratory Report 222-S/RCRA Analytical Laboratories, Single Shell Tank Waste Characterization, Tank 241-U-110, Core 8, Core 8 Composite Rev. 2, Westinghouse Hanford Company, Richland, Washington.

WHC, 1991, Laboratory Report 222-S/RCRA Analytical Laboratories, Single Shell Tank Waste Characterization, Tank 241-U-110, Core 12, Core 12 Composite Rev. 2, Westinghouse Hanford Company, Richland, Washington.

WHC, 1991, Laboratory Report 222-S/RCRA Analytical Laboratories, Single Shell Tank Waste Characterization, Tank 241-U-110, Core 13, Core 13 Composite Rev. 2 , Westinghouse Hanford Company, Richland, Washington. 
WHC, 1991, Laboratory Report 222-S/RCRA Analytical Laboratories, Single Shell Tank Waste Characterization, Tank 241-U-110, Core 14, Core 14 Composite Rev. 2, Westinghouse Hanford Company, Richland, Washington.

WHC, 1991, Laboratory Report 222-S/RCRA Analytical Laboratories, Single Shell Tank Waste Characterization, Tank 241-U-110, Core 15, Core 15 Composite Rev. 2, Westinghouse Hanford Company, Richland, Washington.

\subsubsection{Core Segment Data}

WHC, 1991, Laboratory Report 222-S/RCRA Analytical Laboratories, Single Shell Tank Waste Characterization, Tank 241-U-110, Core 5, Segment 3, 89-040 Rev. 2, Westinghouse Hanford Company, Richland, Washington.

WHC, 1991, Laboratory Report 222-S/RCRA Analytical Laboratories, Single Shell Tank Waste Characterization, Tank 241-U-110, Core 5, Segment 4, 89-041 Rev. 2, Westinghouse Hanford Company, Richland, Washington.

WHC, 1991, Laboratory Report 222-S/RCRA Analytical Laboratories, Single Shell Tank Waste Characterization, Tank 241-U-110, Core 6, Segment 2, 89-043 Rev. 2, Westinghouse Hanford Company, Richland, Washington.

WHC, 1991, Laboratory Report 222-S/RCRA Analytical Laboratories, Single Shell Tank Waste Characterization, Tank 241-U-110, Core 6, Segment 3, 89-044 Rev. 2, Westinghouse Hanford Company, Richland, Washington.

WHC, 1991, Laboratory Report 222-S/RCRA Analytical Laboratories, Single Shell Tank Waste Characterization, Tank 241-U-110, Core 6, Segment 4, 89-045 Rev. 2, Westinghouse Hanford Company, Richland, Washington.

WHC, 1991, Laboratory Report 222-S/RCRA Analytical Laboratories, Single Shell Tank Waste Characterization, Tank 241-U-110, Core 7, Segment 1, 89-046 Rev. 2, Westinghouse Hanford Company, Richland, Washington.

WHC, 1991, Laboratory Report 222-S/RCRA Analytical Laboratories, Single Shell Tank Waste Characterization, Tank 241-U-110, Core 7, Segment 2, 89-047 Rev. 2, Westinghouse Hanford Company, Richland, Waslhington.

WHC, 1991, Laboratory Report 222-S/RCRA Analytical Laboratories, Single Shell Tank Waste Characterization, Tank 241-U-110, Core 7, Segment 3, 89-048 Rev. 2, Westinghouse Hanford Company, Richland, Washington. 
WHC, 1991, Laboratory Report 222-S/RCRA Analytical Laboratories, Single Shell Tank Waste Characterization, Tank 241-U-110, Core 7, Segment 4, 89-049 Rev. 2, Westinghouse Hanford Company, Richland, Washington.

WHC, 1991, Laboratory Report 222-S/RCRA Analytical Laboratories, Single Shell Tank Waste Characterization, Tank 241-U-110, Core 8, Segment 1, 89-050 Rev. 2, Westinghouse Hanford Company, Richland, Washington.

WHC, 1991, Laboratory Report 222-S/RCRA Analytical Laboratories, Single Shell Tank Waste Characterization, Tank 241-U-110, Core 12, Segment 2, 89-070 Rev. 2, Westinghouse Hanford Company, Richland, Washington.

WHC, 1991, Laboratory Report 222-S/RCRA Analytical Laboratories, Single Shell Tank Waste Characterization, Tank 241-U-110, Core 12, Segment 3, 89-071 Rev. 2, Westinghouse Hanford Company, Richland, Washington.

WHC, 1991, Laboratory Report 222-S/RCRA Analytical Laboratories, Single Shell Tank Waste Characterization, Tank 241-U-110, Core 12, Segment 4, 89-072 Rev. 2, Westinghouse Hanford Company, Richland, Washington.

WHC, 1991, Laboratory Report 222-S/RCRA Analytical Laboratories, Single Shell Tank Waste Characterization, Tank 241-U-110, Core 13, Segment 3, 89-075 Rev. 2, Westinghouse Hanford Company, Richland, Washington.

WHC, 1991, Laboratory Report 222-S/RCRA Analytical Laboratories, Single Shell Tank Waste Characterization, Tank 241-U-110, Core 13, Segment 4, 89-076 Rev. 2, Westinghouse Hanford Company, Richland, Washington.

WHC, 1991, Laboratory Report 222-S/RCRA Analytical Laboratories, Single Shell Tank Waste Characterization, Tank 241-U-110, Core 14, Segment 1, 89-077 Rev. 2, Westinghouse Hanford Company, Richland, Washington.

WHC, 1991, Laboratory Report 222-S/RCRA Analytical Laboratories, Single Shell Tank Waste Characterization, Tank 241-U-110, Core 14, Segment 2, 89-078 Rev. 2, Westinghouse Hanford Company, Richland, Washington.

WHC, 1991, Laboratory Report 222-S/RCRA Analytical Laboratories, Single Shell Tank Waste Characterization, Tank 241-U-110, Core 14, Segment 3, 89-079 Rev. 2, Westinghouse Hanford Company, Richland, Washington.

WHC, 1991, Laboratory Report 222-S/RCRA Analytical Laboratories, Single Shell Tank Waste Characterization, Tank 241-U-110, Core 14, Segment 4, 89-080 Rev. 2, Westinghouse Hanford Company, Richland, Washington. 
WHC, 1991, Laboratory Report 222-S/RCRA Analytical Laboratories, Single Shell Tank Waste Characterization, Tank 241-U-110, Core 15, Segment 2, 89-082 Rev. 2, Westinghouse Hanford Company, Richland, Washington.

WHC, 1991, Laboratory Report 222-S/RCRA Analytical Laboratories, Single Shell Tank Waste Characterization, Tank 241-U-110, Core 15, Segment 3, 89-083 Rev. 2, Westinghouse Hanford Company, Richland, Washington.

WHC, 1991, Laboratory Report 222-S/RCRA Analytical Laboratories, Single Shell Tank Waste Characterization, Tank 241-U-110, Core 15, Segment 4, 89-084 Rev. 2, Westinghouse Hanford Company, Richland, Washington. 
WHC-SD-WM-ER-551 Rev. 0

This page intentionally left blank. 
DISTRIBUTION SHEET

\begin{tabular}{|c|c|c|c|c|c|}
\hline \multirow{2}{*}{$\begin{array}{l}\text { To } \\
\text { Distribution }\end{array}$} & \multirow{2}{*}{\multicolumn{3}{|c|}{ From }} & \multicolumn{2}{|l|}{ Page 3 of 4} \\
\hline & & & & \multicolumn{2}{|c|}{ Date $\quad 05 / 22 / 96$} \\
\hline \multicolumn{4}{|l|}{ Project Title/Work Order } & \multicolumn{2}{|c|}{ EDT No. EDT-615395 } \\
\hline \multicolumn{4}{|c|}{$\begin{array}{l}\text { Tank Characterization Report for Single-She11 Tank 241-U-110, } \\
\text { WHC-SD-WM-ER-551. Rev. } 0\end{array}$} & \multicolumn{2}{|c|}{ ECN No. N/A } \\
\hline Name & MSIN & $\begin{array}{l}\text { Te:xt } \\
\text { With All } \\
\text { Attach. }\end{array}$ & Text Only & $\begin{array}{l}\text { Attach./ } \\
\text { Appendix } \\
\text { Only }\end{array}$ & $\begin{array}{l}\text { EDT/ECN } \\
\text { Only }\end{array}$ \\
\hline
\end{tabular}

\section{ONSITE}

Department of Ecology
A. B. Stone
B5-18
$x$

Department of Energy - Richland Operations

J. F. Thompson

$57-54$

W. S. Liou

N. W. Willis

$57-54$

S7-54

$x$
$x$
$x$

\section{ICF-Kaiser Hanford Company}

R. L. Newel1

S3-09

$x$

Pacific Northwest Laboratory

N. G. Colton

K3-75

$\mathrm{K} 7-28$

$\mathrm{K} 5-12$

K7 -94

S. A. Hartley

J. G. Hill

G. J. Lumetta

P7 -25

A. F. Noonan

K9-81

Westinghouse Hanford Company

H. Babad

D. A. Barnes

G. R. Bloom

T. M. Brown

W. L. Cowley

G. L. Dunford

*E. J. Eberlein

D. B. Engelman

J. S. Garfield

ou. D. Guberski

D. L. Herting

G. Jansen

G. D. Johnson

T. J. Kelley

N. W. Kirch

M. J. Kupfer

J. E. Meacham

* Aduotirad Dist Da
57-14

R1-80

H5-61

R2-12

A3-37

S7-81

R2-12

R1-49

H5- 49

R2-06

T6-09

H6-33

S7-15

57-21

R2-11

H5- 49

S7-15 


\section{DISTRIBUTION SHEET}

\begin{tabular}{|c|c|c|c|c|c|}
\hline \multirow{2}{*}{$\begin{array}{l}\text { To } \\
\text { Distribution }\end{array}$} & \multirow{2}{*}{\multicolumn{3}{|c|}{ From }} & \multicolumn{2}{|l|}{ Page 2 of 4} \\
\hline & & & & Date & $05 / 22 / 96$ \\
\hline \multicolumn{4}{|c|}{ Project Title/Work Order } & \multicolumn{2}{|c|}{ EDT No. $\quad$ EDT-615395 } \\
\hline \multicolumn{4}{|c|}{$\begin{array}{l}\text { Tank Characterization Report for Single-Shell Tank 241-U-110, } \\
\text { WHC-SD-WM-ER-551. Rev. 0 }\end{array}$} & \multicolumn{2}{|c|}{ ECN No. N/A } \\
\hline Name & MSIN & $\begin{array}{l}\text { Text } \\
\text { With All } \\
\text { Attach. }\end{array}$ & Text Only & $\begin{array}{l}\text { Attach./ } \\
\text { Appendix } \\
\text { Only }\end{array}$ & $\begin{array}{l}\text { EDT/ECN } \\
\text { Only }\end{array}$ \\
\hline
\end{tabular}

SAIC

20300 Century Boulevard. Suite 200-B

Germantown. MD 20874

H. Sutter

$x$

555 Quince Orchard Rd. Suite 500

Gaithersburg, MD 20878

P. Szerszen

$x$

Los Alamos Laboratory

CST-14 MS-J586

P. 0 . Box 1663

Los Alamos, NM 87545

S. F. Agnew (4)

$x$

Los Alamos Technical Associates

T. T. Tran

B1-44

$x$

Ogden Environmenta]

101 East Wellsian Way

Richland, WA 99352

R. J. Anema

$x$

$\mathrm{CH} 2 \mathrm{M} \mathrm{Hill}$

P. 0. Box 91500

Bellevue. WA 98009-2050

M. McAfee

Tank Advisory Panel

102 Windham Road

Oak Ridge, TN 37830

D. 0. Campbel1

$x$ 


\section{DISTRIBUTION SHEET}

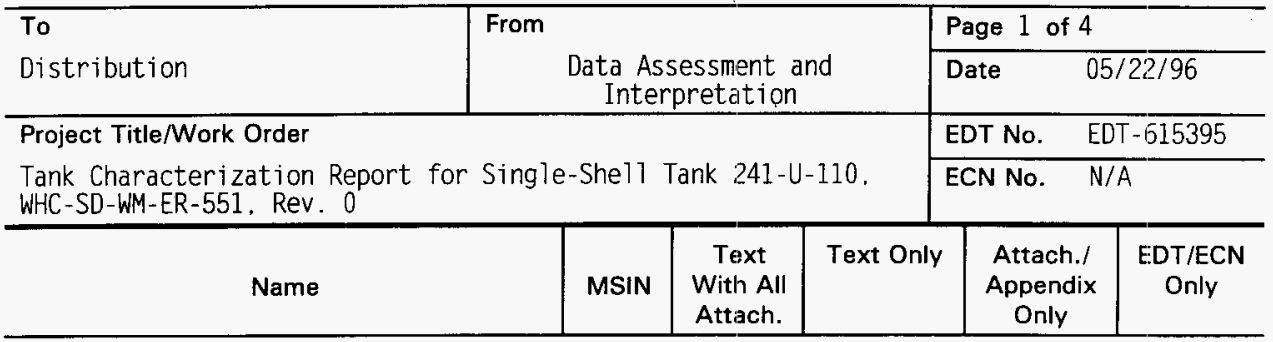

\section{OFFSITE}

Sandia National Laboratory

P.0. Box 5800

MS-0744, Dept. 6404

A7buquerque, NM 87815

D. Powers

Nuclear Consulting Services Inc.

P. 0. Box 29151

Columbus, $\mathrm{OH}$ 43229-01051

J. L. Kovach

$x$

Chemical Reaction Sub-TAP

P.0. Box 271

Lindsborg. KS 67456

B. C. Hudson

$x$

Tank Characterization Panel

Senior Technical Consultant

Contech

7309 Indian School Road

Albuquerque, NM 87110

J. Arvisu

$x$

U. S. Department of Energy - Headquarters

Office of Environmenta] Restoration and Waste Managenent EM-563 12800 Middlebrook Road

Germantown. MD 20874

J. A. Poppitti

$x$

Jacobs Engineering Group

3250 W. Clearwater

Kennewick. WA 99336 
DISTRIBUTION SHEET

\begin{tabular}{|c|c|c|c|c|c|}
\hline \multirow{2}{*}{$\begin{array}{l}\text { To } \\
\text { Distribution }\end{array}$} & \multirow{2}{*}{\multicolumn{3}{|c|}{$\begin{array}{l}\text { Data As } \\
\text { Inte }\end{array}$}} & \multicolumn{2}{|l|}{ Page 4 of 4} \\
\hline & & & & Date & $2 \longdiv { 9 6 }$ \\
\hline \multicolumn{4}{|c|}{ Project Title/Work Order } & \multicolumn{2}{|c|}{ EDT No. EDT-6.5395 } \\
\hline \multicolumn{4}{|c|}{$\begin{array}{l}\text { Tank Characterization Report for Single-Shel1 Tank } 241-\mathrm{U}-110 \text {, } \\
\text { WHC-SD-WM-ER-551, Rev. } 0\end{array}$} & \multicolumn{2}{|c|}{ ECN No. $N / A$} \\
\hline Name & MSIN & $\begin{array}{l}\text { Text } \\
\text { With All } \\
\text { Attach. }\end{array}$ & Text Only & $\begin{array}{l}\text { Attach./ } \\
\text { Appendix } \\
\text { Only }\end{array}$ & $\begin{array}{l}\text { EDT/ECN } \\
\text { Only }\end{array}$ \\
\hline
\end{tabular}

Westinghouse Hanford Company continued

W. C. Miller

C. T. Narquis

D. E. Place

D. A. Reynolds

L. M. Sasaki (2)

L. W. Shelton, Jr.

B. C. Simpson

G. L. Troyer

M. S. Waters

L. R. Webb

K. A. White

Central Files

EDMC

ERC (Environmental Resource Center)

TCRC (10)

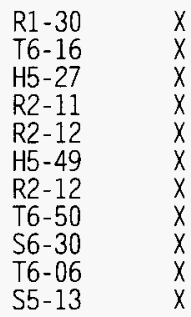

A3-88

H6- 08

R1-51

R2-12

$x$
$x$
$x$
$x$
$x$
$x$
$x$
$x$
$x$
$x$
$x$

$X$
$X$
$X$

$x$
$x$

$x$ 